Portland State University

PDXScholar

Spring 7-3-2018

\title{
A Temperate and Wholesome Beverage: the Defense of the American Beer Industry, 1880-1920
}

Lyndsay Danielle Smith

Portland State University

Follow this and additional works at: https://pdxscholar.library.pdx.edu/open_access_etds

Part of the United States History Commons

Let us know how access to this document benefits you.

\section{Recommended Citation}

Smith, Lyndsay Danielle, "A Temperate and Wholesome Beverage: the Defense of the American Beer Industry, 1880-1920" (2018). Dissertations and Theses. Paper 4497.

https://doi.org/10.15760/etd.6381

This Thesis is brought to you for free and open access. It has been accepted for inclusion in Dissertations and Theses by an authorized administrator of PDXScholar. Please contact us if we can make this document more accessible: pdxscholar@pdx.edu. 


\title{
A Temperate and Wholesome Beverage:
}

The Defense of the American Beer Industry, 1880-1920

\author{
by \\ Lyndsay Danielle Smith
}

A thesis submitted in partial fulfillment of the requirements for the degree of

\author{
Master of Arts \\ in \\ History \\ Thesis Committee: \\ Catherine McNeur, Chair \\ Katrine Barber \\ Joseph Bohling \\ Nathan McClintock \\ Portland State University \\ 2018
}


(C) 2018 Lyndsay Danielle Smith 


\begin{abstract}
For decades prior to National Prohibition, the “liquor question” received attention from various temperance, prohibition, and liquor interest groups. Between 1880 and 1920, these groups gained public interest in their own way. The liquor interests defended their industries against politicians, religious leaders, and social reformers, but ultimately failed. While current historical scholarship links the different liquor industries together, the beer industry constantly worked to distinguish itself from other alcoholic beverages.

To counter threats from anti-alcohol groups, beer industry advocates presented their drink as a wholesome, pure, socially and culturally rich, and economically significant beverage that stood apart from other alcoholic beverages, especially distilled spirits. Alongside these responses, breweries industrialized, reflecting scientific and technological innovations that allowed for modern production, storage, and distribution methods.

Despite popularity and economic successes, the beer industry could not survive the anti-saloon campaigns, the changing nature of the American economy and taxation, political ambitions of the anti-liquor interests, and the influence of the First World War, which brought with it anti-German sentiments. This thesis will uncover the story of the American beer industry’s attempt to adjust to several threats facing it and how beer was ultimately condemned to the same fate as wine and spirits when National Prohibition went into effect.
\end{abstract}




\section{Dedication}

To my family, biological and otherwise, who support me despite not always understanding my choices. That includes my cats whose companionship throughout the pursuit of my graduate degree was truly invaluable. Thank you. 


\section{Acknowledgements}

I never liked the taste of beer. Though my research into America’s beer history inspired me to gradually expand my palate, I did not begin my research based on personal beverage preferences. Instead, this study began as a journey to better understand why there is a passion for craft beer in my current hometown of Portland, Oregon. Independent breweries are common features in the city, and there is an abundance of beer-related events throughout the Pacific Northwest. The more I researched the beer industry in Portland, however, the more I saw its connection to a grander national history.

What follows is a historical narrative that is intended to introduce readers to a momentous period in the history of the American beer industry, focusing on the years between 1880 to 1920 . In short, this period marked the evolution of beer brewing into a significant American industry. Beer consumption rates soon surpassed all other alcoholic beverages. Simultaneously, beer industry advocates uniquely defended beer’s legitimacy in the face of several anti-alcohol campaigns. My research revealed how the beer industry played a complex political, economic, social, and cultural role in American history. Beer connected people and places in both positive and controversial ways. My hope is that this thesis will contribute to existing scholarship while sparking interest in researching American beer history further.

In the future, I hope to expand on this topic and share my research with the public. For one, I want to help digitize primary material and make it more accessible to scholars and the public. Also, I want to study in detail more localized beer histories, such as those 
in the different regions of the United States. The relationships of different races, ethnicities, genders, and nationalities to the beer industry also deserve more scholarly attention. Finally, a comparative history of the American beer industry's experience with alcohol reform to that of other nations might positively complicate the current historical narrative.

As a public historian, I also want to explore different and impactful ways to engage the public in this topic. Already, there are numerous beer collectors and amateur historians with a passion for the history told through material culture. As one of the first stages of researching for this thesis, the American Breweriana Association extended a membership invitation to me. Through the ABA, I met Bryan Anderson, reputed to have one of the most impressive collections of pre-Prohibition breweriana from the Pacific Northwest. Viewing his collection helped me to better appreciate the material culture of the pre-Prohibition beer industry and inspired the subsequent direction of my research. I want to thank Bryan and his wife Laurie for their hospitality. I also want to thank $\mathrm{Al}$ Elkins for connecting me to Bryan and the ABA. I believe the increasing public interest in beer and beer history in the wake of the craft brewing revolution provides a platform to discuss historical connections to the current beer culture. I am curious to find what can be learned as more people, professional historians or otherwise, engage with beer history.

There are several other people that deserve acknowledgement for their contributions to this work. While I remain brief here, I fear that some names will be left out. I apologize in advance and hope that I can personally share my gratitude. For now, I 
must begin by giving special thanks to my thesis committee: Catherine McNeur, Katy Barber, Joseph Bohling, and Nathan McClintock. Their critiques and attention to detail were invaluable. Their trust and kind remarks were far more gracious than I expected and much appreciated. As a whole, my experience with the history department at Portland State University was very pleasant throughout the three years that I studied there. The staff and faculty that I interacted with shared a passion for history and truly cared about the well-being and professional growth of the students.

While I shared sections of this thesis with different people, including commandeering numerous conversations to divulge some of the "cooler" stuff I found in my research, there were a couple notable readers that I wish to acknowledge here. First, my thesis advisor, Catherine McNeur provided incredible patience and guidance every step of the way. She was always accessible and put me at ease when the process overwhelmed me. Furthermore, she was the only one to read and comment on every draft over the last two and half years. I know that this thesis would not have been possible without her encouragement and welcomed criticisms.

Another reader, C.J. Allen, has the distinction of having proofed most of my scholarly work over the last twelve and a half years. He read the final drafts of this thesis, helped me to vocalize my intentions and main arguments in meaningful ways, and talked me through some of the more challenging edits in the final stages. Moreover, over the last several months, he assisted me with this project from a distance while serving in the United States Navy. 
I also want to acknowledge my graduate program cohort as positive influences throughout my studies at PSU. Through countless discussions, positive feedback, and just being wonderful role models, these individuals helped me in researching and writing this thesis. Even more so, they helped me to better appreciate the work we do as historians. I wish Taylor Bailey, Nicole Kindle, Tanya Monthey, Will Schneider, Greta Smith, and Heather Viets the very best in their personal and professional endeavors.

In researching this thesis, I visited the Oregon Historical Society Research Library, Oregon State University Oregon Hops and Brewing Archives, and the City of Portland Archives and Records Center. I want to thank the staff at each of these institutions for their help. Tiah Edmunson-Morton, archivist and curator of the Oregon State University Oregon Hops and Brewing Archives, provided the most help at multiple points during this process. She spoke with me at length more than once and reached out with digital material when I could not make the trip to Corvallis. Her passion for beer history was evident in every one of our exchanges and can be witnessed in the depth and quality of work she does for the archives.

Next, I want to acknowledge my family and closest friends. I dedicated this thesis to them as they provided the encouragement, support, and stability that I needed as my work progressed. To list every person here is not possible, but I do want to recognize a few individuals specifically: my mom and dad; my sisters, Amanda and Kayla; Amanda Gunter; Jessica Dickson; C.J. Allen; and D.J. Kerns. These individuals were consistent, gracious companions throughout this thesis project and my pursuit of a graduate degree. 
Finally, I feel it is important to acknowledge that my appreciation for beer and beer culture have changed over the course of this project. This undertaking challenged me personally and professionally while introducing me to so many wonderful individuals along the way. From reading works from over a hundred years ago to talking with individuals today, I found beer at the center of both passion and controversy. I now enjoy the taste of beer and incorporate beer history into my own history.

Though I did not undertake this project alone, I take full responsibility for the material that follows. Any mistakes or shortcomings are entirely my own. 
Table of Contents

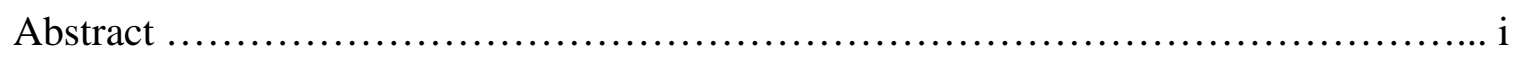

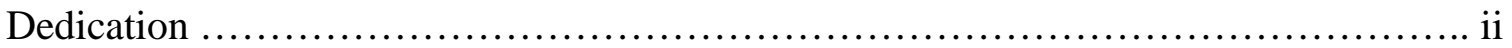

Acknowledgements ...................................................... iii

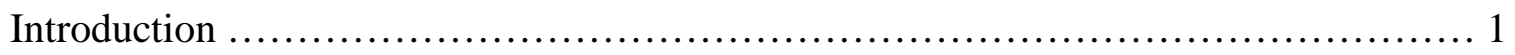

Chapter 1

The Growth of an Industry and the Revitalization of a Movement, 1880-1895 ......... 14

Chapter 2

The Defense of Pure Beer and the Saloon Problem, 1896-1906 ...................... 44

Chapter 3

Beer's Final Struggles Against National Prohibition, 1907-1920 .................... 69

Epilogue

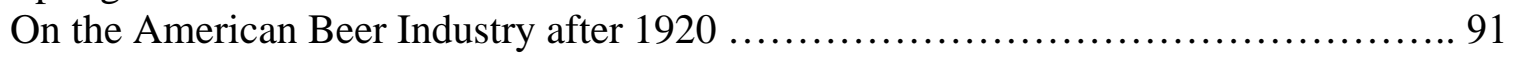

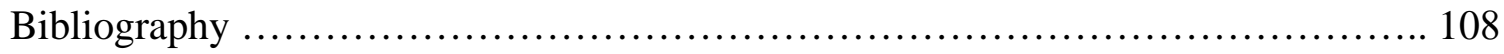




\section{Introduction}

"John Barleycorn is a hero bold, as any in the land, For ages good his fame has stood, and will for ages stand; The whole wide world respect him, no matter friend or foe, Whoe'er they be that make too free he's sure to lay them low. Hey! John Barleycorn, ho! John Barleycorn, Old and young thy praise have sung, John Barleycorn.”

- From folksong titled “John Barleycorn”1

"My concern is that it is so much of the best we breed whom John Barleycorn destroys. And the reason why these best are destroyed is because John Barleycorn stands on every highway and byway, accessible, law-protected, saluted by the policeman on the beat, speaking to them, leading them by the hand to the places where the good fellow and the daring ones foregather and drink deep. With John Barleycorn out of the way, these daring ones would still be born, and they would do things instead of perishing.”

$$
\text { - Jack London }{ }^{2}
$$

Sir Richard Beer, Sir Thomas Good Ale, and Sir William White Wine vowed to kill Sir John Barleycorn. Barleycorn represented the barley plant, and the other characters' creation depended on Barleycorn’s death. That is, according to “The Pleasant Ballad,” a seventeenth-century version of a folksong that was at least a century old even then. The older Scottish and English versions of the ballad told the story of the barley plant, its cultivation, the brewing process, and the effects of the resulting beer on those who consumed it. In some instances, the song included barley wine, as with Sir William White Wine, but barley was the key ingredient in all beverages mentioned.

Steadily, John Barleycorn lost reverence and became a menace to society. The song evolved over the last five centuries to become less of a story about malting the barley and brewing beer and more of a moralistic tale about the effects of the beer on

\footnotetext{
${ }^{1}$ Robert Ford ed., Vagabond Songs and Ballads of Scotland, With Many Old and Familiar Melodies, 2nd ed., vol. 2 (London: Alexander Gardner, 1901), 18.

2 Jack London, John Barleycorn (New York: The Century Co., 1913), 127.
} 
people. When Jack London and Upton Sinclair wrote about John Barleycorn in the late nineteenth and early twentieth centuries, he had transformed to represent all alcoholic beverages that lured and ultimately trapped good people, corrupting them. Where the earliest versions simply warned that too much beer caused problems, the later versions damned the beverage outright. ${ }^{3}$

There are some parallels to how the character from a folksong about beer evolved from a personification of a plant to the personification of an unnecessary evil and how beer itself evolved from a relatively unassuming beverage choice to a dangerous intoxicant. ${ }^{4}$ Songs and stories involving beer, ale, stout, or mead spanned generations and continents. Germanic cultures casually referred to beer as "liquid bread" due in part to its

\footnotetext{
${ }^{3}$ Peter Wood analyzed the early ancestors of the John Barleycorn folk song to show how the overall concept evolved into its more contemporary versions. The songs went back and forth on whether to pity the brutal death and cultivation of Barleycorn to a reverence for his sacrifice. Some also showed reverence for the resulting beer and those that brewed it, such as in "The Pleasant Ballad's" couplet, "All you good wives that brew good ale, God / Turn from you all teen.” In this instance, "teen” translates to mean "injury” or "grief." However, characteristic of these songs, reverence was followed by warning. The next couplet in "The Pleasant Ballad” went, "But if you put too much liquor in, the Devil / Put out your een." "Een” translates to "eyes." Wood did not provide social or cultural analysis for the changes between the versions. He focused on the changes and continuities themselves, relating the versions over time. For the purposes of this thesis, Wood's analysis established some continuities and changes between the oldest known samples of a folk song concerning beer. Wood's analysis was especially helpful since writers from the late nineteenth and early twentieth centuries often referenced John Barleycorn, using the name in a variety of contexts. Peter Wood, “John Barleycorn: The Evolution of a Folk-song Family,” Folk Music Journal 8, no. 4 (2004), http://www.jstor.org/stable/4522718 (accessed September 24, 2017).

${ }^{4}$ At the Fifteenth International Congress Against Alcoholism held in Washington, D.C. in 1920, presenters raised concerns over beer's physiological, economic, political, and social effects. In each instance, they deemed beer an intoxicant with negative effects on individuals' health and populations at large. Each expressed animosity towards saloons, and one claimed that beer was responsible for most of Europe's alcoholism. Three presenters placed emphasis on beer at the congress: De Lancy Carter, medical doctor and the President of the American Medical Society for the Study of Alcohol and Other Narcotics; A. Holitscher, medical doctor and General Secretary of the International Medical Total Abstinence Association; and Harvey W. Wiley, former Chief Chemist in the U.S. Department of Agriculture and noted for his leadership in the Pure Food Movement. Ernest H. Cherrington, ed. Proceedings of the Fifteenth International Congress Against Alcoholism, Held at Washington, D.C., U.S.A, September 21-26, 1920 (Washington, D.C.: n.p., 1921).
} 
daily consumption and traditionally heavier styles. ${ }^{5}$ Still, others associated it with drunkenness and moral vice. By the turn of the twentieth century in the United States, those who found beer just as corrupt as all other alcoholic beverages campaigned to eliminate it once and for all. A unique relationship existed between the beer industry and social reform movements before the Eighteenth Amendment to the U.S. Constitution prohibited the manufacture and sale of beverage alcohols in 1920. This thesis examines the different ways in which the beer industry navigated its relations with the Temperance, Pure Food, and Prohibition movements between 1880 and 1920.

Sources from the turn of the twentieth century remembered John Barleycorn in a variety of ways, from a revered subject to a hated one, to somewhere in-between. Similarly, opinions on National Prohibition varied. There were more than two sides to the conversation, as both the anti-liquor advocates and liquor interests maintained many different viewpoints on the nation's liquor question. When National Prohibition went into effect on January 16, 1920, the New York Times printed an article titled, “John Barleycorn Died Peacefully at the Toll of $12 .{ }^{, 6}$ What follows is an analysis of how the beer industry rose to prominence in the United States and fought to maintain its legitimacy in the face of social and political reform.

\footnotetext{
${ }^{5}$ Wulf Schiefenhövel and Helen Macbeth, preface to Liquid Bread: Beer and Brewing in Cross-Cultural Perspective, edited by Wulf Schiefenhövel and Helen Macbeth (New York: Berghahn Books, 2013), xi-xii. Advertisements and publications often featured the term "liquid bread" in reference to beer. Both bread and beer contain yeast, but the term had cultural meaning too. For example, on the same day the Seattle Brewing \& Malting Company purchased a label patent for “Rainier Beer” in 1907, Thomas Ryan's Consumers' Brewing Company out of Syracuse, New York purchased a label patent for "Liquid Bread." Official Gazette of the United States Patent Office 128 (Washington, D.C.: Government Printing Office, 1907), xvii, xxxiii, 1289.

${ }^{6}$ David E. Kyvig, Repealing National Prohibition, 2nd ed. (Kent, OH: The Kent State University Press, 2000), 19.
} 
National Prohibition was not an “experiment,” as President Herbert Hoover alluded to in his inauguration speech in $1929 .{ }^{7}$ Those who supported the Eighteenth Amendment did not intend for it to be an experiment, much less to be repealed within thirteen years. Laws placing strains on the production and sale of alcoholic beverages existed well before an amendment to the United States Constitution solidified its prohibition nationwide. The final movement sealing the fate of alcohol was linked to antialcohol sentiment spanning a century and generations of Americans. However, that link did not make the Eighteenth Amendment inevitable. The Temperance Movement changed methods of influence and practice several times over the decades, with varying degrees of success depending on time and location.

Even though temperance was a popular subject in American society and politics in the late nineteenth and early twentieth centuries, there were enough inconsistencies within the movement that National Prohibition did not appear inevitable to everyone. By no means did the various liquor industries believe that such a serious law would pass. When it did pass, many liquor interests brought court cases against the government, claiming the law was unconstitutional and demanding restitution for lost business and reduced capital. Citing the protection of personal liberties by the Constitution and American capitalism, members of the liquor industries decried such radical legislation. The beer industry was among the most vocal and organized of the liquor industries to confront prohibitionists.

\footnotetext{
${ }^{7}$ Catherine Gilbert Murdock, Domesticating Drink: Women, Men, and Alcohol in America, 1870-1940
} (Baltimore: The Johns Hopkins University Press, 1998), 140. 
Historical scholarship at present does not provide adequate focus on the preProhibition beer industry's reaction to temperance and other social reforms. In fact, most Prohibition scholarship conflates the different liquor industries, even though beer industry advocates actively sought to separate themselves. ${ }^{8}$ At best, the beer industry receives a few pages or footnotes. Scholars are slowly taking interest in America's beer history, but the pre-Prohibition era remains underrepresented. ${ }^{9}$ This thesis seeks to analyze the pre-Prohibition beer industry on its own terms by focusing on the way it addressed the Temperance, Pure Food, and Prohibition movements that threatened its very survival.

A large problem with studying the pre-Prohibition beer industry is the challenge of locating primary source material linked to specific breweries. It is difficult to locate and access specific breweries' records, due in large part to the era of National Prohibition from 1920 to 1933. Several thousand breweries closed because of the alcohol ban. If their records were not outright destroyed, they were barely preserved. Some internet databases provide access to materials, but few company records are easily accessible. Even the

\footnotetext{
${ }^{8}$ Most of the beer-specific works concerning this era come from popular writers and journalists. These sources are invaluable in providing a synopsis of period publications and advertisements, but they often lack peer review. Some examples used in this thesis are Stanley Baron, Brewed in America: A History of Beer and Ale in the United States (Boston: Little, Brown, and Company, 1962); Pete Dunlop, Portland Beer: Crafting the Road to Beervana (Charleston, SC: American Palate, 2013); and Maureen Ogle, Ambitious Brew: The Story of American Beer (Orlando, FL: Harcourt, Inc., 2006).

${ }^{9}$ The craft brewing revolution over the last four decades brought more attention to the American beer industry from the public and historians alike. Academic and public institutions are incorporating more beer and brewing specific programs, departments, and archives. Some notable examples include the National Museum of American History's American Brewing History Initiative (begun in 2016) and Oregon State University's Oregon Hops and Brewing Archives (begun in 2013). A unique feature of the Oregon Hops and Brewing Archives is the growing collection of oral histories. Archivist Tiah Edmunson-Morton conducted most of the interviews in the collection, which consist of Pacific Northwest brewers, hops growers, food writers, and more.
} 
larger breweries changed owners so frequently over the last one hundred years that relatively few archives remain. ${ }^{10}$ However, a growing interest in the American beer industry because of the craft beer movement encouraged the collection and preservation of pre-Prohibition beer materials. For some time, these sources have been underutilized by professional historians. ${ }^{11}$ Perhaps that will not be the case in the future as more professional organizations work with the American breweriana community to better understand the beer industry through material culture. ${ }^{12}$

For this thesis, I made the national beer industry my focus, and I relied heavily on primary source material from newspapers and journals, organization and industry publications, advertisements, government documents, and popular literature. I also referenced political and social science studies, histories of social reform movements, social and medical studies of alcohol and its consumption, food histories, local and regional brewery and beer histories, agricultural histories, labor histories, and women's histories for secondary source material.

\footnotetext{
${ }^{10}$ Some early and middle-twentieth century researchers and biographers were able to access records that are currently difficult to locate. Notable works for this thesis include: Thomas C. Cochran, The Pabst Brewing Company: The History of an American Business (New York: New York University Press, 1948) and Baron, Brewed in America.

${ }^{11}$ Historian David Fahey called for more research on American beer history using Ohio as a case study. He argued that non-academic historians' research is invaluable to such studies. David M. Fahey, "Old-Time Breweries: Academic and Breweriana Historians,” Ohio History 116 (2009): 101-121.

${ }^{12}$ Breweriana organizations, such as the American Breweriana Association (ABA) founded in 1982, provide networking opportunities for beer memorabilia and paraphernalia collectors. The ABA also began a museum collection housed in the National Brewery Museum in Potosi, Wisconsin. ABA members are currently funding a digital preservation project to scan all issues of The Western Brewer: and Journal of the Barley, Malt and Hop Trades. The journal went under a few name changes, but was published from 1876 to 1960. Pre-Prohibition issues of the journal provided great insight into the beer and affiliated industries for this thesis, including reactions to threats against those industries. Historical scholarship will no doubt benefit from digitization projects like this. For more information on the digitization project, visit https://americanbreweriana.org/breweriana/westernbrewerjournals.php.
} 
The following thesis is an interpretation of sweeping trends in literature from both anti-alcohol sympathizers and pro-beer advocates. In many ways, it is how they wanted to be seen and remembered. Though not exhaustive, such analysis serves as an introduction to an underexplored subject and provides insight into how an industry fought for legitimacy in the face of social and political reform. ${ }^{13}$ It will also show that the National Prohibition that eventually manifested was not inevitable, nor were its motivations as obvious. Concerns over the morality of food, social hygiene, gender roles, and what it meant to be an American in the changing national and global climates were some of the contributing factors. Amid the anti-alcohol campaigns were members of the beer industry and the affiliated businesses, and they did not ignore the threats to their livelihoods.

Three important factors contributed to the successes and failures of both social reform and the beer industry in America between 1880 and 1920: industrialization, urbanization, and immigration. In many cases, interests collided based on one or more of these factors. Scientific and technological innovations allowed the beer industry to grow and prosper, leading to the creation of several national beer brands. The more prominent brewing companies established offices in different cities across the nation, many within growing urban areas. Urban areas, in turn, with higher concentrations of people and

\footnotetext{
${ }^{13}$ While the pre-Prohibition beer industry itself experienced vast changes during the focus years of this thesis, I will only concentrate on those changes directly related to the Temperance, Pure Food, and Prohibition movements. The internal labor disputes and competitive practices of the different brewers, for example, will not be discussed beyond their relevance. While these subjects deserve extensive analysis, such attention lies beyond the goals for this thesis.
} 
businesses, provided more lucrative markets for beer. Finally, the impact of immigration on the beer industry cannot be overstated. Brewers often came from immigrant families or were immigrants themselves. Since the mid-nineteenth century, Americans increasingly preferred to drink German-brewed lagers. ${ }^{14}$ Moreover, when considering the connection between breweries and the saloon culture, the beer industry owed a large part of its business to the immigrant and working-class consumers.

Concurrent to the beer industry's rising success, the cultural and social shock of the Industrial Revolution created an atmosphere for social reform. Industrialized food and beverage production raised public and individual health concerns while the growth of cities and the changing demographics within those cities encouraged social reformers to confront poverty and what they considered associated social ills. Those involved in the Temperance, Pure Food, and Prohibition movements supported Americanized lifestyles and found fault in the immigrant cultures and diets that allowed for intoxicating beverages, thus contributing to conceived social ills.

Social reform centered around protecting and purifying the American home. What constituted an American home, how the family members should conduct themselves, and what ought to be consumed frequented advertisements, public presentations, and popular and organization-based literature. Ideas of social hygiene and gender roles played into

\footnotetext{
${ }^{14}$ Several successful German brewers produced lagers and established distribution centers in urban centers across the United States, effectively creating national brands. Massive marketing campaigns, the salty and meaty diets of most Americans, and the desire for less-alcoholic beverages helped to promote lagers over other beer styles. Such names as Anheuser-Busch, Pabst, Miller, and Schlitz owed much of their success to their lager beers. The lighter, crisper, and effervescent beverage sold more than the heavier, darker, more alcoholic beer styles. Cochran, The Pabst Brewing Company, 116.

In 1909, the secretary to the United States Brewers' Association claimed that lager beer comprised ninety-five percent of the beer industry's business. Hugh F. Fox, "The Prosperity of the Brewing Industry," The Annals of the American Academy of Political and Social Science 34, no. 3 (Nov., 1909), 55.
} 
these arguments. Social reformers questioned equality and democratic practice within the nation as well as the liquor question, affecting different socio-economic classes, races, ethnicities, nationalities, and genders within the United States in different ways. The more vocal and published parties in the alcohol debates were predominantly white, middle-class, Protestant Christians. While social reform was meant to instill a specific social standard adhered to by all those who called themselves "American," a selective group meant to formulate that standard based on their own morals and behaviors. Social reform affected different socio-economic classes, races, ethnicities, nationalities, and genders within the United States in different ways. However, the alcohol debates, both in favor and against prohibition, tended to reserve attention for women and the working classes, especially immigrants. ${ }^{15}$ Therefore, as this thesis is focused on the sweeping trends of the pro-beer and anti-alcohol literature of the era, treatment of several racial and ethnic minorities is limited to specific cases.

Women were especially influential in social reform movements, including the success of National Prohibition. For many women, alcohol reform and then its elimination stemmed from protecting the American home from alcoholism and related domestic violence. Several thousand women nationwide joined temperance groups. The

\footnotetext{
${ }^{15}$ In the late twentieth century, research into alcohol consumption patterns and alcohol-related issues increasingly accounted for cultural and social factors such as race, ethnicity, immigration experiences, genetics, and socio-economic status. As this research continues to expand, historians will have more opportunities to place it within historical context. Some articles on the changing nature of alcohol research are Raul Caetano, Catherine L. Clark, and Tammy Tam, "Alcohol Consumption Among Racial / Ethnic Minorities: Theory and Research," Alcohol Health \& Research World 22, no. 4 (Fall 1998): 233-241 and Karen Chartier and Raul Caetano, "Ethnicity and Health Disparities in Alcohol Research," Alcohol Research \& Health 33, nos. 1-2 (Winter-Spring 2010): 152-160.
} 
Woman’s Christian Temperance Union (WCTU) was amongst the most influential temperance groups to support alcohol reform as well as other social reforms.

The beer industry responded to several threats by presenting beer as a pure, wholesome, temperance beverage beneficial to all Americans and the American economy. Brewers and other beer advocates invested in advertisements and publications distinguishing beer from other alcoholic beverages. To them, beer, consumed in moderation, offered sustenance alongside refreshment. Conversely, they argued that distilled liquors like whiskey and rum could not be consumed in moderation and did not provide the health benefits of beer.

Moreover, many referred to beer as a home beverage. Prior to industrialization, families, primarily women, commonly brewed and consumed beer at home. For those that did not brew at home, there was a long-standing tradition of sending a family member to a local tavern or saloon to fill the household pail, or "growler," with beer at least once a day. ${ }^{16}$ Once distribution and storage options improved, more breweries increased home delivery efforts. Overall, beer industry advocates found that, to achieve acceptance as a legitimate American industry and a legitimate piece of American life, they had to show that consuming beer could enhance the well-being of individuals and communities.

\footnotetext{
${ }^{16}$ Steven D. Barleen, "'Rushing the growler': can rushing and working-class politicization in the Gilded Age and Progressive Era," Labor History 55, no. 4 (October 2014): 519-537, http://www-tandfonlinecom.proxy.lib.pdx.edu/doi/pdf/10.1080/0023656X.2014.948710 (accessed February 9, 2016).
} 
This thesis is divided into three chapters emphasizing three periods of significant reform and counter-reform efforts, followed by an epilogue. The first chapter focuses on the years 1880 to 1895 and details the rise of the beer industry in America, the changing nature of American beer itself, and the revitalized Temperance Movement that pushed for more stringent anti-alcohol legislation. ${ }^{17}$ The success of the beer industry overshadowed ambitions to curb its consumption, especially among working class and immigrant populations. Still, beer industry advocates worked to distinguish beer from other alcoholic beverages, even terming beer a "temperance beverage.”

The second chapter shows how leading organizations of the Temperance Movement changed tactics around 1895 and ends with the passing of the Pure Food and Drug Act of 1906. Local option laws prohibiting the sale of alcohol within certain areas replaced the more radical prohibition measures sought in the previous decades. Simultaneously, and often in conjunction with the Temperance Movement, members of the Pure Food Movement increased political activism and sought reform of food preparation, production, and distribution. Temperance and pure food reformers alike not only questioned the content of industrialized food, but they also questioned the morality of certain foods. During this period, the beer industry had to adapt to challenges brought on by local option laws and address concerns about the nature of their product. Advocates defended the materials used by brewers and methods of production and distribution.

\footnotetext{
${ }^{17}$ Scholars recognize this period as the second wave of temperance. The first wave having been before the Civil War and the third wave to come in the mid-1890s. Paul Aaron and David Musto, "Temperance and Prohibition in America: A Historical Overview,” in Mark H. Moore and Dean R. Gerstein, eds. Alcohol and Public Policy: Beyond the Shadow of Prohibition, Panel on Alternative Policies Affecting the Prevention of Alcohol Abuse and Alcoholism (Washington, D.C.: National Academy Press, 1981), 148.
} 
Further distinguishing beer from other alcoholic beverages, beer advocates capitalized on the Pure Food Movement to not only defend the purity of their product but its wholesome nature.

The final chapter, beginning around 1907 and ending with the implementation of the Eighteenth Amendment in 1920, shows the final struggle of the beer industry to remain legitimate in the face of the Prohibition Movement. Anti-alcohol organizations were much better organized and politically active in the early twentieth century, and radical prohibition dominated mere temperance reform. The liquor industries, including the beer industry, had largely rested on their economic success and not organized to the level of the prohibitionists. However, as this chapter demonstrates, the beer industry made changes to their anti-prohibition campaign and increased efforts to distinguish themselves from the other liquor industries in hopes to remain legitimate. Even so, the beer industry could not survive the effects of taxation reform and international war. The First World War provided a strong platform for prohibitionists, and they capitalized on food conservation efforts and the fears associated with Germany. Headlines and prohibition publications accused many recognizable brewers of German dissent of antiAmerican and pro-German sentiment.

In close, the epilogue discusses some of the aftermath of January 16, 1920 as it pertained to the American beer industry. Even after the passage of the Eighteenth Amendment, beer industry advocates hoped that their less-alcoholic products would be within regulations of non-intoxicating beverages. After all, the amendment had developed out of the war-time prohibition measure that merely limited but did not prohibit beer 
production and sale outright. ${ }^{18}$ However, the enforcement act of the Eighteenth

Amendment, better known as the Volstead Act, defined all beverages containing more than one-half of one percent of alcohol by volume to be intoxicating beverages.

Therefore, the act applied equally to beer as to the other liquors. Outraged, brewers brought lawsuits against the government, but the alcohol limits established by the Volstead Act remained active until the Twenty-First Amendment repealed National Prohibition in 1933. The nation experienced great changes during the Prohibition era, and it took several decades for the beer industry to recover from the ban. However, it did recover and even experienced a craft brewing revolution beginning in the late 1970s that continues at present. Through studying the different periods of American beer history, one witnesses the intimate relationships forged between the beverage and many significant social, political, and economic markers of the nation’s history.

\footnotetext{
${ }^{18}$ Prohibitionists intended to stop the use of all foodstuffs in production of any alcoholic beverages as a measure of the food conservation bill, better known as the Lever Act. There was considerable contention in Congress over whether to prohibit the production of beer and wine along with distilled spirits. Ultimately, Andrew Volstead's enforcement act followed the wishes of the prohibitionists. Peter H. Odegard, Pressure Politics: The Story of the Anti-Saloon League (New York: Columbia University Press, 1928), 166-171.
} 


\section{Chapter 1}

The Growth of an Industry and the Revitalization of a Movement, 1880-1895

"All beer has a notably small percentage of alcohol, the strongest ales and porters showing less than many specimens of cider; all contain an appreciable amount of solid nutriment ... all are palatable and wholesome, and all are adapted to take the place of ardent spirits and thus reduce intemperance and drunkenness to a minimum."

- F. W. Salem, United States Brewers' Association ${ }^{19}$

"Water is the strongest drink. It drives mills; it's the drink of lions and horses, and Samson never drank anything else. Let young men be teetotalers if only for economy's sake. The beer money will soon build a house.”

$$
\text { - C. H. Spurgeon, Reverend }{ }^{20}
$$

Open any Portland, Oregon city directory from the 1880s and there are at least

three things that will certainly be there: a list of breweries, dozens of saloons, and a large advertisement for Henry Weinhard's lager beer. ${ }^{21}$ Weinhard was a German-born brewer who immigrated to the Oregon Territory in the early 1850s. He began brewing in Vancouver, Washington but soon after established his own brewery in the young city of Portland. By the 1880s, Weinhard’s City Brewery constituted an entire city block and sold beer locally, up and down the West Coast, and as far away as Siberia and Japan. He was a prominent member of the local German-American community, owned several properties and businesses in the area, and invested in the overall success of the city. In 1888, he even offered - perhaps in jest - to connect a hose from his brewery to a new fountain being constructed in the business district intended to serve the city’s workers and animals. As his contribution, he wanted to supply free lager to the citizens. The city

\footnotetext{
${ }^{19}$ F.W. Salem, Beer, Its History and Its Economic Value as a National Beverage (Hartford, CT: F.W. Salem \& Company, 1880), 69.

${ }^{20}$ Rev. C. H. Spurgeon, “A Word to the Boys,” The Union Signal 9, no. 37 (Sept. 27, 1883), 6.

${ }^{21}$ Several breweries around the nation advertised their beers in city directories. These advertisements tended to be more elaborate than those in newspapers. Stanley Baron, Brewed in America: A History of Beer and Ale in the United States (Boston: Little, Brown, and Company, 1962), 260-261.
} 
ultimately denied his offer, but it at least demonstrated his philanthropic nature and confidence in his beer. ${ }^{22}$

Weinhard's journey to the West Coast was rather typical of many German brewers of the mid-nineteenth century. Immigrants established communities in the West, and the increasing number of German brewers found several locations to settle. Cities such as St. Louis, Milwaukee, Chicago, Denver, San Francisco, Portland, and Olympia boasted German-American communities and consumers. German-style lagers also interested American beer-drinkers and became the beer preferred nationally by the 1880s. ${ }^{23}$ In short, beer followed the frontier. These frontier towns embodied something significant to the American beer industry: potential.

Despite the harsh realities of living in frontier communities, there were several advantages to brewing in the West. For one, there was a market for beer. Industrialization in Europe and on the East Coast of the United States created new jobs that attracted people to cities. As cities got crowded, or as new opportunities arose to make a better living, people steadily moved westward. Chief among the first European settlers of the western territories were working-class men. Lumberjacks, fishermen, seamen, soldiers, gold seekers, and other laborers found several opportunities in the frontier towns. Families ventured west as well, but in comparatively fewer numbers at first. Western

\footnotetext{
${ }^{22}$ Aukjen T. Ingraham, "Henry Weinhard \& City Brewery,” Oregon Historical Quarterly 102, no. 2 (Summer, 2001). Charles Erskine Scott Wood, “The Skidmore Fountain,” Oregon Historical Quarterly 34, no.6 (Jun., 1933), http://www.jstor.org.proxy.lib.pdx.edu/stable/20610788 (accessed Jan. 26, 2016): 97102.

${ }^{23}$ F.W. Salem, of the United States Brewers’ Association, attributed lager’s popularity in 1880 to nostalgia, tradition, refreshment, relatively low alcohol content, and how it complimented workers' diets in America and Europe. Salem, Beer, Its History, 72-83. Refer to pages 18-21 below for more information on the rise of lager beer in America.
} 
brewers profited off selling their product to those populating the small towns and

developing cities.

Settlers who moved to the West Coast also found an environment with

agricultural potential for brewers and the rising beer industry. West Coast commercial

brewing had three main concentrations: Portland, Oregon; San Francisco, California; and

Olympia, Washington. These cities especially benefited from being located near fields of

hops. ${ }^{24}$ As agricultural businesses improved, so did the access to key ingredients for

producing beer. Advances within the brewing industry and American infrastructure

further increased West Coast brewing production and distribution. ${ }^{25}$

Across the nation, beer grew in popularity in the late nineteenth century, with beer consumption rates surpassing those of other alcoholic beverages. By the 1880s, beer's

status as a national beverage stemmed from significant advances in brewing science and technology. ${ }^{26}$ Between 1880 and 1895, beer production in America more than doubled. ${ }^{27}$

\footnotetext{
${ }^{24}$ Historian Peter Kopp's history of hops in Oregon's Willamette Valley provided valuable insight into a complex global history of a significant ingredient used to make beer. His study detailed the agriculture, politics, and people that distinguished the hops industry within the region and globally. Peter A. Kopp, Hoptopia: A World of Agriculture and Beer in Oregon's Willamette Valley (Oakland, CA: University of California Press, 2016). Another great resource on the American hops industry is Michael A. Tomlin, Tinged With Gold: Hop Culture in the United States (Athens, GA: University of Georgia Press, 1992).

${ }^{25}$ Samuel A. Batzli mapped recorded American breweries between 1612 and 2011, showing concentrations during significant brewing periods. When comparing his maps dating to 1920, the concentrations began in the Northeast and slowly expanded westward as time progressed. By 1865, the Midwest region rivaled the Northeast in the number of breweries. Between 1866 and 1920, the number of breweries reached its peak, and three regions held the highest concentrations of breweries: Northeast, Midwest, and West Coast, respectively. Batzli acknowledged the influence of immigration, and industrialization on the brewing industry as it moved farther west. The access to ingredients, industrial innovations, and increasing markets for beer helped Western brewers establish successful trades. By 1880, the United States ranked third in production of beer to the United Kingdom and Germany. Samuel A. Batzli, "Mapping United States Breweries," in The Geography of Beer: Regions, Environment, and Societies, ed. Mark Patterson and Nancy Hoalst-Pullen (New York: Springer, 2014), 33-38.

${ }^{26}$ As larger brewers expanded their markets, certain brands became recognizable across the nation.

${ }^{27}$ Production went from 13,300 barrels to 33,600 barrels a year. One barrel equaled 31 U.S. gallons. U.S. Bureau of the Census, Historical Statistics of the United States, Colonial Times to 1970, Bicentennial Edition, Part I (Washington, D.C.: U.S. Government Printing Office, 1975), 690-691.
} 
Some of the more recognizable brewers to flourish in this period were Adolphus Busch of St. Louis, Captain Frederick Pabst and Frederick Miller of Milwaukee, George Ehret and Jacob Ruppert, Sr. of New York City, Henry Weinhard of Portland, and Adolph Coors of Golden, Colorado.

Amid its growth, and perhaps in part due to it, the beer industry faced backlash from members of the revitalized Temperance Movement. The dominant temperance groups in the 1880s and early 1890s, the Women’s Christian Temperance Union and National Prohibition Party, took a more radical stance than many of their predecessors and advocated complete legal abstinence from all alcoholic beverages. Beer advocates responded to the anti-liquor position by distinguishing beer from other alcoholic beverages, promoting beer as a temperance drink, and reinforcing the industry’s legitimacy through economic contributions. Despite increased efforts from temperance advocates, all attempts to pass a national prohibition law failed and only a handful of states embraced prohibition. ${ }^{28}$ Even so, changes in both the beer industry and the Temperance Movement during this period added to an already unsteady relationship between the two.

The success of the beer industry of the late nineteenth century had roots in American culture itself. Brewing in America began with English settlement in the

\footnotetext{
28 “Temperance” could mean moderate drinking, drinking only light alcoholic beverages like beer or light wines, or complete abstinence from drinking alcohol. The Temperance Movement included all these interpretations. Context clues usually help to establish which definition a writer or speaker espoused. Unless specifically stated, I will continue to use "temperance” to refer to the movement generally and "prohibition” or "prohibitionist” to refer to circumstances or people that explicitly advocated legislation banning the manufacture and sale of alcoholic beverages.
} 
seventeenth century when settlers brought beer with them from England. They began

brewing English-style ales, stouts, and porters as soon as they had the means. Early

Americans considered beer to be a healthy drink that was preferable to the often-

questionable drinking water. ${ }^{29}$ Historically, beer was recognized as a "universal

beverage” consumed by all types of Americans from all levels of society. ${ }^{30}$

Even so, commercial beer was not as prosperous as ciders or distilled liquors until

the post-Civil War era. Brewing remained a common task within households, but

relatively few skilled brewers and undeveloped agriculture limited commercial brewing.

Colonists and early Americans simply did not have the infrastructure to support large-

scale brewing. They imported beer from Europe or nearby settlements, but that proved

expensive and insufficient to meet demands. Alcoholic apple cider could be produced

much easier than beer. Also, increased trade from New England with Barbados in the late

seventeenth century made production and access to rum much easier than other alcoholic

beverages. ${ }^{31}$

\footnotetext{
${ }^{29}$ Ruth Bordin, Woman and Temperance: The Quest for Power and Liberty, 1873-1900 (Philadelphia: Temple University Press, 1981), 5. Baron, Brewed in America, 6.

${ }^{30}$ The universality of beer comes from several factors. One being that, especially in England at the time of colonization, beer was often brewed and consumed at home when clean water or other beverages were difficult to obtain. Also, the English and other Europeans that immigrated to the American colonies had long-standing traditions of drinking beer. As for the less-wealthy classes, a considerable factor was the affordability of beer. By the 1880s, beer typically sold for five cents a glass in saloons across America. The added practice of providing a free lunch with a drink purchase made the cheaper beverage even more economical. Furthermore, the popular light lagers were less filling and intoxicating and, thus, consumers could drink more volume before meeting their intoxication limits. Baron, Brewed in America, ix-x, 3-13. John Koren, Economic Aspects of the Liquor Problem: An Investigation Made for the Committee of Fifty under the Direction of Henry W. Farnham, Secretary of the Economic Sub-Committee (Boston: Houghton, Mifflin and Company, 1899), 219.

Historian Madelon Powers examined the process of community-building in urban America relating to saloons from 1870 to 1920 . Her study showed the working-class saloongoers' interpretation of their own culture and community. Drinking habits underwent several changes over the decades, with beer consumption in saloons becoming significant by 1870. Madelon Powers, Faces Along the Bar: Lore and Order in the Workingman's Saloon, 1870-1920 (Chicago: The University of Chicago Press, 1998), 80-86. ${ }^{31}$ John Allen Krout, The Origins of Prohibition (1925; reis., New York: Russell \& Russell, 1967), 31-39.
} 
However, the influx of German immigrants in the 1840s played a significant role in developing the American beer industry. Beer had a long-standing significance in Germanic culture, and the German immigrants brought their cultural traditions with them. For German-speaking peoples of northern Europe, drinking beer accompanied celebrations, negotiations, and formations of allegiances. Traditionally, Germans viewed beer as "liquid bread" which promoted vitality and community. From being a gift given by the gods and drinking fests surrounding warfare in ancient times to more modern social gatherings, beer remained a major tenet amongst Germans. German immigrants also established beer gardens, which, differing from saloons or dancing parlors, provided entertainment for families alongside the beverage. ${ }^{32}$ English and other Western European-style beers remained in production, but the German-style lagers quickly became the most consumed beer styles nationwide. ${ }^{33}$

Brewers and consumers alike valued lager for the taste, consistency, and preserving power between brews. "Lager” comes from the German word lagern, which means "to rest," and lager yeast fermented on the bottom of the vat at cool temperatures. During fermentation, the yeast fed on the sugar content of the malt forming carbonic-acid gas (carbon dioxide) and ethyl alcohol, making beer an intoxicant. Following fermentation, which would last several days, most of the yeast was removed and the beer

\footnotetext{
32 Maureen Ogle, Ambitious Brew: The Story of American Beer (Orlando, FL: Harcourt, Inc., 2007), 17. Baron, Brewed in America, 179-181. K. Austin Kerr, Organized for Prohibition: A New History of the AntiSaloon League. (New Haven: Yale University Press, 1985), 27. Powers, Faces Along the Bar, 190-192.

${ }^{33}$ Historian Perry R. Duis placed the arrival of lager in the United States in Philadelphia with brewer John Wagner in 1840. Duis paralleled the migration of lager westward with the movement of the population, especially the German immigrants. Lager reached Chicago in 1854 through Valentin Busch and Michael Brand. Perry R. Duis, The Saloon: Public Drinking in Chicago and Boston, 1880-1920 (1983; repr., Urbana, IL: Illini Books, 1999), 16-17.
} 
aged in wooden casks in a cool place for two to three months before being distributed.

The result was a less volatile, lighter, more malty, less-alcoholic drink than topfermenting ales. $^{34}$

The success of lager in the United States owed to several factors. One significant factor was the change in American drinking habits as the nation became more industrialized. New, factory-style work settings helped to create a public drinking culture where co-workers patronized restaurants and saloons during meal breaks or in-between work shifts. As another factor, historian Thomas C. Cochran argues in a history of the Pabst Brewing Company of Milwaukee that Americans desired the lighter, drier lagers at least in part because of America's climate conditions. He notes a general desire to drink larger quantities of beer but an added complication of the hot summers that most Americans experienced. As a result, Americans developed a taste for lighter-bodied beers. Cochran also noted that Americans desired lighter-colored beers as an added aesthetic preference. ${ }^{35}$ The preference for lighter lagers increased as more Americans also valued beverages with lower alcohol content, due in large part to the influence of the Temperance Movement. ${ }^{36}$

\footnotetext{
${ }^{34}$ Baron, Brewed in America, 14. Ogle, Ambitious Brew, 15-16. Gary Meier and Gloria Meier, Brewed in the Pacific Northwest: A History of Beer-Making in Oregon and Washington (Seattle: Fjord Press, 1991), 20-21. Tom Acitelli, The Audacity of Hops: The History of America's Craft Beer Revolution (Chicago: Chicago Review Press, 2013), xvi.

35 Thomas C. Cochran, The Pabst Brewing Company: The History of an American Business (New York: New York University Press, 1948), 116. An article in the Sunday Oregonian in 1882 even defended the American preference for German-style beers over English-style ales and stouts. "Pure Beer, A Newspaper's Defense of the Great Malt Beverage,” Sunday Oregonian, November 19, 1882.

${ }^{36}$ Powers, Faces Along the Bar, 82-83. Ranjit S. Dighe, "A Taste for Temperance: How American Beer Got to be So Bland,” Business History 58, no. 5 (2016): 752-784.

Though he does not explicitly draw this same conclusion, Henry W. Farnam reported that the American people from 1840 to 1898 steadily increased consumption per capita of malt liquors and decreased that of distilled liquors. Uncertain of the reason, he wrote, "The fact remains that our progress has been in the direction of moderation.” Koren, Economic Aspects of the Liquor Problem, 34-35.
} 
Finally, a major factor in lager's national success owed to advancements in the brewing industry itself and the aggressive business strategies of a select group of lager brewers. During America's Industrial Revolution in the nineteenth century, brewers capitalized on scientific and technological innovations to modernize and expand the brewing industry. Changes to the brewing process, infrastructure, and storage and distribution methods allowed breweries to produce more beer and ship it farther than ever before ${ }^{37}$ Brewery consolidations into larger companies became a common characteristic of the industry. The number of American breweries decreased from 2,191 to 1,248 between 1880 and 1890, but the industry’s capital increased from $\$ 91.2$ million to $\$ 232.5$ million. ${ }^{38}$ The use of trademarks and bottle-labeling alongside aggressive advertising added to the national success of larger brewery companies. They also established

\footnotetext{
${ }^{37}$ The largest increase in beer consumption, from 6.9 gallons to 11.4 gallons per capita, occurred between 1880 and 1885. Kerr, Organized for Prohibition, 21. Economist David A. Wells, writing from the perception of internal revenue taxation, placed the consumption rate per capita of beer in 1893 at over sixteen gallons. David A. Wells, The Theory and Practice of Taxation (New York: D. Appleton and Company, 1900), 56.

${ }^{38}$ Kerr, Organized for Prohibition, 15. Free competition in the nineteenth century allowed larger breweries to purchase smaller ones and either operate them or close them, effectively eliminating their competitors. In consolidating multiple breweries under one owner, the buyer might choose to use the acquired facilities for producing their namesake brand of beer or to continue using the smaller brewery's brand name to solicit local brand loyalty. It also was much more economical to purchase an existing outfit instead of erecting new facilities. Furthermore, the more successful brewers like Pabst and Busch invested in real estate and retail outlets, which allowed them to sustain economic downturns or compete with lower beer prices. It became a common occurrence for large breweries to buy out those ambitious brewers that invested high capital in their own breweries but could not compete with the lower prices offered by the larger operations. To protect their interests against domestic and international consolidation efforts and pricing competition, some breweries joined together in brewery associations. These were usually limited to specific locations, such as the New Orleans Brewing Co. and the Pittsburgh Brewing Company. These associations had limited successes against industry competition, but it was a common practice until the Prohibition Era. Similar consolidation efforts and smaller brewery associations exist in the modern brewing industry. The laws vary across locations to limit the types of licenses a brewery can obtain, but the practice of large brewery corporations purchasing smaller ones, often keeping the smaller brand's label on the beer, is common today. Simultaneously, smaller craft brewers are increasingly merging aspects of their businesses to compete with both the larger brewery corporations and the numerous other craft brewers emerging out of the craft beer revolution. Baron, Brewed in America, 265-273. Kopp, Hoptopia, 173-174, 183, 185. John Kell, “These 4 Brewers Have Been Booted from the Top 50 Craft Beers List,” Fortune, http://fortune.com/2017/03/15/mergers-change-craft-brewers-list/ (accessed May 11, 2018).
} 
agencies in major cities across the country, increasing their regional or national

presence. ${ }^{39}$ Breweries like Anheuser-Busch Brewing Association, Pabst Brewing

Company, and Miller Brewing Company grew into brands recognized and consumed

nationally.

Over the course of the nineteenth century, the art of brewing developed into a

science. ${ }^{40}$ Brewers needed to combat inconsistencies between brews and find better ways to store and ship their beer before they could distribute it to farther markets. Some

brewers even hired scientists to research the brewing process and discover more efficient means of production and storage. To support the growing industry, brewery architecture changed from wooden buildings resembling residential properties to multi-story brick factory-style buildings fitted with the latest machinery. Embracing change added to the success of the beer industry and allowed for national branding.

Of note, the work of chemists Louis Pasteur and Emil Christian Hansen in the late nineteenth century significantly enhanced the beer industry. French chemist Louis Pasteur discovered in 1860 that alcoholic fermentation correlated with the life and organization of the yeast cell. ${ }^{41}$ He studied the properties of yeast and concluded a decade later that eliminating bacteria in yeast would also eliminate any pathogens in the beer and

\footnotetext{
${ }^{39}$ Baron, Brewed in America, 258-262, 267-268.

${ }^{40}$ One Hundred Years of Brewing: A Complete History of the progress made in the Art, Science and Industry of Brewing in the world, particularly during the last Century (Chicago: H.S. Rich \& Co., 1901), iii. Baron highlighted the "art and mystery of brewing" that existed prior to the 1870s. He compared the successful brews to a baker or cook's success relying on practice and instinct. Historian Thomas Cochran also acknowledged the period before the 1870s to be largely dependent on brewing skill and lacking the control of consistency between brews. He told how the Pabst Brewing Company, founded in Milwaukee in 1844, introduced new mechanisms and scientific knowledge into their brewing process to become one of the most successful brewing companies in the United States. Baron, Brewed in America, 17-18. Cochran, The Pabst Brewing Company, 102-128.

41 "Bacteriology and Brewing,” The British Medical Journal 1, No. 2890 (May 20, 1916), 727.
} 
result in rare brewing failures. He developed a method of heating the finished product in high enough temperatures to eliminate any remaining bacteria, called pasteurization. American brewers adopted pasteurization as early as 1872 with Adolphus Busch of St. Louis. Fluent in English, German, and French, Busch read Pasteur’s work and incorporated it into his brewing process by placing bottles of finished beer in water that gradually heated to the appropriate temperature to kill the bacteria. Soon, all breweries in America would adopt pasteurization. As time progressed, conveyor belts moved the bottles through mechanized pasteurizers. ${ }^{42}$

Brewers also incorporated Danish biochemist Emil Christian Hansen’s studies in the differentiations between yeast species into the brewing process. ${ }^{43}$ Brewers typically used wild yeasts or imported yeasts from various locations without really knowing the properties that distinguished one from the other. Hansen argued that brewers could better control the nature and quality of each brew by using specific strains of pure culture yeast in the fermentation process. The invention of Baltimore clippers and expansions of the railroads helped American brewers access the specific yeast species, and they adopted Hansen's pure culture yeast in the late 1880s. ${ }^{44}$

\footnotetext{
${ }^{42}$ Ogle, Ambitious Brew, 62-64. Louis Pasteur, Studies on Fermentation: The Diseases of Beer, Their Causes, and the Means of Preventing Them, translated by Frank Faulkner and David Constable Robb (London: Macmillan \& Co., 1879), 38-39.

${ }^{43}$ Hansen conducted his research at the laboratory funded by Carl Jacobsen who owned the Carlsberg Breweries in Copenhagen, Denmark. Like other brewing laboratories across the western world, he said that the work being done at the Carlsberg Laboratory "was to test by independent investigation the theories advanced by science and to develop them by continued research into a scientific groundwork as complete as possible for malting, brewing, and fermenting operations." Max Henius, "Danish Beers and Continental Beer Gardens." The Western Brewer: and Journal of the Barley, Malt and Hop Trades 41, no. 4 (October, 1913): 162.

${ }^{44}$ Baron, Brewed in America, 175-176, 238-241.
} 
Technologically, steam power provided better heat consistency and control throughout the kettle. By the 1840s, brewers replaced the long wooden paddles used in the mashing process with steam-powered engines and used steam in the boiling process. ${ }^{45}$ Until then, they had boiled the mash in copper kettles over an open fire. At first, brewers refitted their old fire kettles, but gradual improvements in design incorporated steam technology. As in the old fire kettles, copper continued to be used for its superior heat conductivity, durability, and easy maintenance. ${ }^{46}$

The invention of artificial ice machines also significantly expanded the possibilities for the beer industry. Prior to the late nineteenth century, brewers paid for ice harvested from frozen lakes and ponds and shipped to the brewery. This restricted brewing capabilities in hotter climates, especially hindering brewing in the southern United States. However, first cold storage rooms and then artificial ice machines provided a solution. The first cold storage warehouses containing ice blocks appeared in the 1860s. Insulation and preservation techniques such as adding salt to the ice helped to improve temperature control. In the 1890s, mechanical refrigeration gradually replaced imported ice. These machines produced enough ice to cool the beer during the brewing process, storage, and distribution.

As artificial refrigeration became iceless, breweries benefited from the improved temperature control, the space freed from ice storage and packing, and the more efficient use of space within the brewery. Once brewers did not have to store their beer underground in cold cellars, the brewing could be done completely above ground,

\footnotetext{
${ }^{45}$ Meier and Meier, Brewed in the Pacific Northwest, 20.
}

${ }^{46}$ One Hundred Years of Brewing, 66-67. 
eliminating costly piping or relocation of the beer. Above-ground rooms also had better ventilation, further benefiting brewery employees. Artificial refrigeration also benefited the hops industry, a key ingredient in beer. ${ }^{47}$

In addition, the changes in bottling technology made commercial beer more available to different types of retail outlets and for home consumption. Prior to the 1880 s, bottling was not a common practice. Between federal tax laws requiring that the beer cross a public thoroughfare prior to bottling and the likelihood that beer would spoil in the bottle, brewers mostly opted to limit bottling their beer. If a consumer wanted to drink a specific brewery's beer at home without purchasing an entire keg, then they would send someone to a local saloon with a pail, or "growler," to be filled. Pasteurization, refrigeration, and further innovations in bottling design led to an increasingly stable method for shipping beer domestically and abroad. Additionally, with developments in

\footnotetext{
${ }^{47}$ Susanne Freidberg, Fresh: A Perishable History (Cambridge: The Belknap Press of Harvard University Press, 2009), 93. Meier and Meier, Brewed in the Pacific Northwest, 23-27. One Hundred Years of Brewing, 42. Cochran reported that the Pabst Brewing Company purchased its first artificial ice machine in 1879 and had stopped purchasing natural ice entirely by 1888. As far as productivity, Pabst's ice machines helped reduce shrinkage in the volume of beer between storage tank and shipping container due to foaming waste. Beer foams less under lower temperatures, so the lower temperatures provided by ice machines than rooms filled with natural ice helped limit foaming waste. Pabst lost nearly twenty-two percent to shrinkage in 1886, but this number reduced to ten percent in 1889. Cochran, The Pabst Brewing Company, 107-110.

The first iceless refrigerating systems took-up a huge amount of space and weighed up to 200 tons. The motors to power these systems weighed several tons themselves. However large and invasive, larger breweries began investing in artificial ice machines in the 1880s as well as hiring steamships and railcars with refrigeration options. On a small scale, it would take until the late 1920s for iceless refrigeration to be readily available and affordable for most American households. Until then, consumers either purchased ice harvested from water sources in winter or they purchased ice produced in a plant. Steadily, ice producers advertised personal iceboxes to keep at home and be constantly restocked with their product. Concerns about the health of natural versus artificial ice arose, but most Americans who regularly used ice opted for artificial ice by the turn of the century. Mostly, this had to do with availability, convenience, and the advertising efforts of ice producers. Further developments in the American diet included more perishable foods and added to the desire to have artificial refrigeration in the home. The U.S. Food Administration's war-time conservation efforts during the First World War supported eating more perishable foods on the home front to so longer-lasting foods could ship overseas, which in turn associated artificial refrigeration with patriotism. Freidberg, Fresh, 18-39.
} 
railroads and cold storage, mail-order beer became more common. Bottled beer also sold in groceries, hotels, restaurants, and wholesale liquor stores. ${ }^{48}$

Saloons were among the more popular public places to drink beer. Depending on the saloon, patrons found bowling, billiards, singing, dancing, and more. Some saloons catered to women by providing treats like ice cream and substituting alcoholic beverages with coffee. The saloon culture boomed in the years following industrialization. In fact, saloons catered to so many working-class patrons between 1870 and 1900 that they were widely known as “workingman’s clubs,” or less glamorously as "poor man’s clubs.”49 During that period, the number of saloons in the United States tripled from nearly 100,000 to $300,000 .^{50}$

Saloons remained independent establishments from breweries until competition led several brewers to invest in specific saloons. In cities like Chicago, with large markets for beer, local breweries also had to compete with national brands. In most cases, brewers offered discounts and gratuities to saloonkeepers as incentives to sell their products. For the local brewer especially, such expenses left profits low. Contracts with saloonkeepers were also suspect with several cases of promises not being kept or bills unpaid. To counteract such issues, brewers began investing in saloons by financing fixtures such as bars, mirrors, or sideboards to saloonkeepers. Commonly, brewers added a clause in the fixture mortgages limiting the brands of beer that saloonkeepers could sell. Brewery

\footnotetext{
${ }^{48}$ Baron, Brewed in America, 241-246. Meier and Meier, Brewed in the Pacific Northwest, 21-23. Hugh F. Fox, "The Prosperity of the Brewing Industry," The Annals of the American Academy of Political and Social Science 34, no. 3 (Nov., 1909): 51-53.

${ }^{49}$ Powers, Faces Along the Bar, 13-15.

${ }^{50}$ Pete Dunlop, Portland Beer: Crafting the Road to Beervana (Charleston, SC: American Palate, 2013), 38.
} 
representatives also purchased retail liquor licenses and leased them to saloonkeepers. In some instances, the brewers leased the properties and found tenants to run the saloons. If a saloonkeeper reneged on his agreements or proved unprofitable, then he could be replaced without the brewery losing control of the license to sell liquor in his saloon. Eventually, more brewers purchased or built their own buildings to lease to saloonkeepers. This practice, known as the tied-house system, increased in the 1880s and continued until National Prohibition in 1920. Saloons not only provided profits for brewers but increased brand loyalty through advertising and fixtures throughout the establishments, further fueling the success of the brewing industry. ${ }^{51}$

Only, tying themselves so securely to saloons proved problematic for breweries in relation to temperance reform. In the late nineteenth century, members of a revitalized Temperance Movement noticed the growth of the beer industry and its influence on the saloon business. Most temperance advocates, especially the more radical prohibitionists, considered saloons to embody some of the basest social evils. This was not just because of the alcohol being served but the illicit entertainments popularly associated with saloons, such as gambling and prostitution. ${ }^{52}$ Anti-saloon campaigning remained very influential in the decades leading to National Prohibition.

\footnotetext{
${ }^{51}$ Duis, The Saloon, 15-45.

${ }^{52}$ It is important to note that the day-to-day activities within and associated with saloons were often overshadowed by the folklore of the saloon. In reading period advertisements, newspaper articles, popular literature, and other publications, one will find hyperbolic statements and emotional scenes. Opposing the saloon, songs and plays embodied the pleas of children to their drunken fathers to leave the barstool and come home. Children reportedly died from secretly drinking alcohol from saloons. On the other side of the argument, jovial scenes of weddings, celebrations, and comradery solidly placed the saloons within the community culture. Madelon Powers' study of the saloon culture between 1870 and 1920 included the folklore associated with saloons and their place within local communities. Powers, Faces Along the Bar, passim.
} 
One of the boldest and most significant anti-alcohol campaigns of the nineteenth century focused on closing the saloons and other alcohol retail outlets. Women led the campaign which became known as the Women’s Praying Crusade or Women’s Crusade. It began in Ohio in 1873 and spread across the nation, only lasting for a little over a year. Women gathered in front of saloons, beer gardens, and all-manner of liquor dealers to sing hymns and pray that the establishments would close their doors and rid towns of their bad influence. This caused upheavals in many towns and cities. The crusade resulted in multiple arrests and displayed the seriousness of temperance to several women nationwide. ${ }^{53}$

The Women’s Crusade embodied more than a campaign against alcohol sales. The Temperance Movement in the late nineteenth century provided an instrumental platform for women's involvement in social and political reform. ${ }^{54}$ In that period, women

\footnotetext{
${ }^{53}$ Bordin, Women and Temperance, 15-33. Additional sources on the Women's Crusade include Mary F. Eastman, The Biography of Dio Lewis, Prepared at the Desire and with the Cooperation of Mrs. Dio Lewis (New York: Fowler and Wells, 1891); and Annie Wittenmyer, History of the Women's Temperance Crusade (Philadelphia: Office of the Christian Woman, 1878).

${ }^{54}$ Bordin, Women and Temperance, xvi-xviii. Kerr, Organized for Prohibition, 35. The study of the relationships between the women's suffrage and prohibition movements in the late nineteenth and early twentieth centuries involves complex interactions of advocates from both movements that go beyond the scope of this thesis. The significance here is that there were women who chose to support temperance and prohibition in a socially and politically dynamic time in American history. Women's suffragists, women's rights activists, and women prohibitionists espoused various political and social identities. These identities changed as time progressed and new generations faced changing national and international politics, economics, and social philosophies. In historian Ross Evans Paulson's study of the women's suffrage movement as it related to prohibition, he ultimately arrives at the conclusion that all parties represented separate and sometimes overlapping aspects of the search for equality and for democratic social control. In his study, he compares the American experience with those of other nations with similar concerns. Ross Evans Paulson, Women's Suffrage and Prohibition: A Comparative Study of Equality and Social Control (Glenview, IL: Scott, Foresman and Company, 1973). Historian Catherine Gilbert Murdock also addresses how the women's suffrage and prohibition movements related to one another in her study on the patterns of alcohol use among Americans from 1870 to 1940. Catherine Gilbert Murdock, Domesticating Drink: Women, Men, and Alcohol in America, 1870-1940 (Baltimore: The Johns Hopkins University Press, 1998).
} 
were generally relegated to a specific sphere of influence: the home and family. ${ }^{55}$ Under that pretense, their socially acceptable ambitions lay in protecting or enhancing the quality of life at home. In the early Temperance Movement, many women led by example within the home where they were expected to educate family members on moral living. Though active in temperance organizations throughout their existence, restrictions on women's legal identities limited their roles within the organizations. Most significantly, woman did not gain voting rights in the United States until the twentieth century.

Similarly, many temperance organizations allowed women to become members, but very few allowed them to vote on internal matters. Working within their sphere of influence, many women exercised their political and professional voices in creative ways, such as forming their own professional organizations, advocating for legislation supporting social reform, and embracing new education possibilities.

Out of the Women's Crusade came the most notable woman-led temperance organization to date, the Woman’s Christian Temperance Union (WCTU). The WCTU defended "home protection" in a male-dominated, industrialized culture. ${ }^{56}$ The Union

\footnotetext{
${ }^{55}$ Alcoholism plagued both public and private spheres of society, and women more often than men experienced the negative effects of both. By the twentieth century, several cities and towns throughout the United States legally banned women from entering saloons, the public spheres for drinking. In fact, contemporary social rules of masculinity connected men to alcohol and social drinking. Excessive drinking often led to domestic abuse, and women with alcoholic and abusive husbands often had to endure the abuse until divorce grew more socially acceptable. Women's clubs formed across the nation to combat domestic issues related to drunkenness. Murdock, Domesticating Drink, 10-17.

${ }^{56}$ Though always present in the movement, most early temperance groups would not allow women to speak at meetings or serve on committees. Several women looked for ways to represent their sex in maledominated temperance groups. When Susan B. Anthony attempted to speak at the 1852 convention of the New York State Temperance Society, she was denied because she and the other women were only invited to listen and not to speak. Anthony, along with Elizabeth Cady Stanton, organized the Women's State Temperance Society a few months later. The organization did not last more than a year, but it was not the last woman-led temperance group. Steadily, women's organizations and clubs sprung up around the country. Bordin, Women and Temperance, xvi-xviii, 5-9. Dale E. Soden, "The Woman’s Christian Temperance Union in the Pacific Northwest: The Battle for Cultural Control,” The Pacific Northwest
} 
advocated temperance legislation as well as several other social and political reform measures. State chapters and a national chapter represented the Union. ${ }^{57}$ Frances Willard served as president of the national branch of the WCTU from 1879 to her death in 1898. Highly motivated and charismatic, Willard led the organization with a "do everything” program that included support for the National Prohibition Party, temperance education, women's suffrage, and labor rights. ${ }^{58}$

The increase in women's activism owed in part to the changing class organization in the United States due to industrialization. The growth of the middle class and changing ideas of domestic labor allowed more women additional leisure-time to devote to social reform movements, including the Temperance Movement. ${ }^{59}$ In fact, though reputedly

Quarterly 94, no. 4 (Fall 2003): 197-207, http://www.jstor.org/stable/40491692 (accessed May 13, 2017), 197.

${ }^{57}$ The international chapter of the WCTU, founded in 1883, drafted a petition addressed to governments around the world "for the protection of the home," placing the home well within the woman's sphere of influence and in domestic and international news. World's Woman's Christian Temperance Union, "Petition of the World's Woman's Christian Temperance Union for the Protection of the Home addressed to the Governments of the World,” The Union Signal 17, no. 20 (May 14, 1891), 1.

${ }^{58}$ Richard F. Hamm, Shaping the Eighteenth Amendment: Temperance Reform, Legal Culture, and the Polity, 1880-1920 (Chapel Hill, NC: The University of North Carolina Press, 1995), 24-25. The Prohibition Party and WCTU had a formal relationship from 1880 to 1882 in the Prohibition Home Protection Party, but that relationship gradually diminished over changing methods and goals, internal disagreements, and regional differences. Adam Chamberlain, Alixandra B. Yanus, and Nicholas Pyeatt, "The Connection Between the Woman's Christian Temperance Union and the Prohibition Party,” SAGE Open 6, no. 4 (2016): 1-8, https://doi.org/10.1177/2158244016684373 (accessed December 13, 2017).

Though some supporters of women's suffrage also advocated legally banning alcoholic beverages, some did not. For example, women's rights activist Abigail Scott Duniway, put women's suffrage above prohibition. She argued that women needed to secure the right to vote and then could choose prohibition or not. She also feared that associating the Temperance Movement with women's suffrage, especially prohibition, would distract from the cause. In response to the Women's Crusade, Duniway wrote, "So, you are praying earnestly that God will remove the yoke of wickedness from the necks of the intemperate; but the first prayer that will be effectually answered will be made with ballots in your hands to keep company with the prayers in your hearts.” Abigail Scott Duniway, Path Breaking: An Autobiographical History of the Equal Suffrage Movement in Pacific Coast States, 2nd ed. (Portland, OR: James, Kerns \& Abbott Co., 1914), 63-64. Duniway, "Crusaders, What Think You?," in "Yours for Liberty:" Selections from Abigail Scott Duniway's Suffrage Newspaper," ed. Jean M. Ward and Elaine A. Maveety (Corvallis, OR: Oregon State University Press, 2000), 106. Ward and Maveety, “Yours for Liberty,” 20.

${ }^{59}$ Prior to the home economics and domestic science revolution in America at the turn of the twentieth century, domestic labor was generally seen as a job for the lower and immigrant classes. While not every 
open to all women, the WCTU consisted of mostly white, middle-class, Protestant, conservative women. ${ }^{60}$

During the 1880s and early 1890s, the WCTU was the largest and most active temperance organization in the country, followed by the National Prohibition Party. Both groups represented the more radical temperance advocates who supported the absolute cessation of alcohol production and consumption, better known under the general designation of “prohibitionists.” Where the WCTU supported different political parties on various issues, the Prohibition Party formed to specifically address America's liquor problem. ${ }^{61}$ The Prohibition Party began as a state-level political party in Michigan, Illinois, and Ohio, and expanded into a national party in 1869. Primarily, Prohibition Party members came from the temperance wing of the Republican Party but felt that the major parties were not making enough progress in anti-liquor legislation. They put the liquor issue at the forefront of their party platform. The party had strong membership in the Northeastern and Midwestern states, mainstays of traditional Republicanism. ${ }^{62}$ Until

\footnotetext{
American family could afford to hire household servants, at least the image of domestic labor as a servant's job permeated the American middle- and upper-classes. It was considered an increase in social status for a man's wife and other female relatives to remain unemployed outside of the home. Therefore, the social motivation to have women stay at home and still have servants to at least assist in housekeeping and childrearing duties allowed a larger number of women additional leisure-time. Nearly a quarter of families in American cities employed at least one servant by the 1880s. Helen Zoe Veit, Modern Food, Moral Food: Self-Control, Science, and the Rise of Modern American Eating in the Early Twentieth Century (Chapel Hill: The University of North Carolina Press, 2013), 78-79.

Historian Ruth Bordin outlined these factors for women's increased involvement in the Temperance Movement and included other factors like the decrease in birthrates amongst middle to uppermiddle class white women, the social benefits of urbanization, an increase in common school education for girls, and the breadth of the social programs organizations such as the WCTU. Bordin, Woman and Temperance, 10-13.

${ }^{60}$ Hamm, Shaping the Eighteenth Amendment, 24.

${ }^{61}$ The lower-cased term "prohibitionist" refers to those that supported legal prohibition of alcohol, whereas the upper-cased term "Prohibitionist" refers to members of the National Prohibition Party.

${ }^{62}$ Hamm, Shaping the Eighteenth Amendment, 22-24.
} 
the rise of the Anti-Saloon League (ASL) in the middle-1890s, the WCTU and National Prohibition Party dominated the social and political activities of the Temperance Movement.

The beer industry had a unique relationship with the different manifestations of the Temperance Movement throughout the decades. Like beer itself, temperance in America had its roots in the first European settlements, with some periods garnering more public attention and popularity than others. ${ }^{63}$ For a time, Americans consumed more distilled liquors and hard cider than beer and wine, due in large part to availability and quality. Therefore, temperance advocates focused more on those beverages at first. Arguably, the most intemperate period in American history was between 1790 and 1830 when the annual per capita consumption of alcohol reached four gallons. ${ }^{64}$

Between the 1820s and 1840s, the organized temperance groups used moral suasion to promote temperance values to the American public. This meant that groups cited religious and moral motivations for eliminating alcohol consumption and petitioned people to sign pledges to abstain from alcoholic beverages. They remained largely

\footnotetext{
${ }^{63}$ Historian John Allen Krout wrote that the law-makers and enforcers of the colonial era drew so much attention to problems with drunkenness that they left a reputation of gross intemperance that future generations latched onto. However, Krout cited several examples of colonial sources commenting on the relative sobriety of American towns to European ones. Krout, The Origins of Prohibition, 26-31. ${ }^{64}$ This rate fell to about two gallons after 1830 and remained there for a century. W. J. Rorabaugh, The Alcoholic Republic: An American Tradition (New York: Oxford University Press, 1979), 5-10. Hamm, Shaping the Eighteenth Amendment, 19-21. Historians such as Rorabaugh tend to agree that drunkenness in this period was a response to rapid growth and change in the American society coupled with a greater supply of whiskey. Farmers growing grain on the western side of the Appalachian Mountains found converting their harvest into whiskey was often easier and more profitable than transporting it to larger markets. Kerr, Organized for Prohibition, 16-17.
} 
outside of direct political action, even though their teachings were intended to affect every level of society. Then, the temperance groups in the 1850s became more politically active, resulting in thirteen statewide prohibition measures. ${ }^{65}$ However, all but five states overturned these measures by the end of the Civil War. Only three states (Maine, New Hampshire, and Vermont) maintained prohibition in $1875 .{ }^{66}$

Temperance advocates of the late nineteenth century maintained the earlier generations’ characteristic appeal to morality as they backed state and national prohibition legislation, Prohibition candidates from local to federal levels of government, and worked to educate the public on the various problems associated with alcohol - what contemporaries often referred to as the "liquor problem.” ${ }^{67}$ Both the Prohibition Party and the WCTU published material on temperance and led public gatherings. Three major weekly newspapers founded in the 1880s and early 1890s reached over 100,000 subscribers. ${ }^{68}$ Plays dramatized the effects of alcohol on individuals, families, and the whole of society. ${ }^{69}$ Children learned about the evils of alcohol in schools through temperance textbooks and special lectures. Several preachers led sermons warning

\footnotetext{
${ }^{65}$ An intimate relationship existed between the Christian religion and the various manifestations of the Temperance Movement in America, and morality was always a factor in anti-liquor arguments, but temperance advocates began turning towards political and legal means of battling intemperance during the 1850s. Historian John Allen Krout's study published only five years into National Prohibition purposefully ended in 1851 due to this shift towards political activism. Krout, Origin of Prohibition, foreword.

${ }^{66}$ Hamm, Shaping the Eighteenth Amendment, 25.

${ }^{67}$ Ernest Hurst Cherrington, The Evolution of Prohibition in the United States of America: A Chronological History of the Liquor Problem and the Temperance Reform in the United States from the Earliest Settlements to the Consummation of National Prohibition (Westerville, OH: The American Issue Press, 1920), 165-168.

${ }^{68}$ The National Prohibition Party published the Voice and the Lever while the WCTU published the Union Signal. Hamm, Shaping the Eighteenth Amendment, 22-26. Kerr, Organized for Prohibition, 35-36.

${ }^{69}$ One example was William Pratt's 1889 theatrical adaptation of T. S. Arthur's novel, Ten Nights in a Barroom. The narrator witnesses the corruption and downfall of several characters in a small town all due to alcohol abuse and the dangers associated with saloons.
} 
congregations of the evils of alcohol. ${ }^{70}$ These efforts helped establish a level of antialcohol sentiment across the nation, with some areas being more accepting than others. ${ }^{71}$

The beer industry responded to anti-alcohol sentiment by appealing to individuals, families, and governments on behalf of the wholesome nature of beer and the economic benefits of the beer industry. Breweries strongly promoted beer as a temperance beverage and safe for the whole family. Unlike distilled liquors, beer provided the benefits of food and medicinal tonics. Similarly, also unlike distilled liquors, one could easily consume beer in moderation. ${ }^{72}$ Frederick William Salem of the United States Brewers’ Association placed beer in the moderate position between total abstinence and excess, between water and distilled liquors. ${ }^{73}$ Beer advocates also argued that beer was a safer alternative to beverages with higher alcohol content. By distancing themselves from distillers, brewers hoped the stigmas associated with alcohol would be attached to distilled liquors. ${ }^{74}$ As a

\footnotetext{
${ }^{70}$ Using language consistent with most temperance literature, Reverend Justin Edwards wrote in a manual on temperance meant for other preachers and their congregations, "Though [intoxicating liquor] affords a momentary gratification, at the last it bites like a serpent, and stings like an adder. It tends to form an artificial, unnecessary, and dangerous appetite, and thus to lead to drunkenness and ruin.” Justin Edwards, The Temperance Manual (London: S.W. Partridge \& Co., 1871), 7.

${ }^{71}$ In general, radical temperance had more success in less-urban and more conservative-leaning areas. Hamm, Shaping the Eighteenth Amendment, 22, 25, 28.

${ }^{72}$ Contemporary writers used different names to refer to the same types of alcohols. Some of the more common names for distilled liquors were "ardent spirits," "distilled spirits," and "hard drinks." For beer, some of the more common terms were "fermented liquors," "malt liquors," and "malted beverages." Wine and hard cider were also fermented drinks and often linked with beer under the term "fermented liquors," but most sources distinguished them from beer, especially as beer consumption surpassed both wine and hard cider consumption.

${ }^{73}$ Salem, Beer, Its History, 11.

${ }^{74}$ A history of the brewing industry published in 1901 described American brewers' early dislike of being placed in the same class as distilled spirits. Specifically, brewers protested being taxed the same as the other alcohols when the revenue law passed in 1862. One Hundred Years of Brewing, 226.
} 
result, brewers would ideally avoid any legal restrictions placed on high-alcohol beverages.

Debates over the distinction between beer and distilled liquors were not new. As far back as 1811, Benjamin Rush, a temperance activist and physician, provided insights into the harmful effects of "ardent spirits" or "spirituous liquors" on the human body and mind. He argued, however, that malt liquors were economical, nourishing, and agreeable in taste. He even provided recipes for concoctions involving beer. Conversely, he maintained that distilled liquors should be avoided altogether. ${ }^{75}$ Beer advocates decades later embraced and promoted Rush's distinction between the alcohols.

Beer advocates embraced medicinal uses for alcohol and physicians’ warnings against stronger alcohols. Physicians commonly prescribed alcohol to patients for varying ailments. In a medicinal handbook published in 1879, the section on alcohol warned against the excessive use of strong alcoholic beverages on the human body, but it also contained accepted medicinal uses. For example, the authors suggested that alcohol could refresh the nervous system after intense physical or mental labor, increase the patient's appetite, and aid in digestion. ${ }^{76}$ The handbook's section on hops, a main ingredient in most beer styles, promoted the plant as a mild sedative that also invigorated digestion.

\footnotetext{
${ }^{75}$ Rush established his opinion that beer and light wines should be used in place of distilled liquors in a 1778 treatise titled Directions for Preserving the Health of Soldiers. His 1811 treatise expanded on his opinions towards alcoholic beverages. Benjamin Rush, An Inquiry into the Effects of Ardent Spirits upon the Human Body and Mind, with An Account of the Means of Preventing and of the Remedies for Curing Them, 6th ed. (New York: Cornelius Davis, 1811), 13. Krout, Origins of Prohibition, 71-74.

${ }^{76}$ Alfred Stillé and John M. Maisch, The National Dispensatory: Containing the Natural History, Chemistry, Pharmacy, Actions and Uses of Medicines, Including those Recognized in the Pharmacopoeias of the United States, Great Britain, and Germany, with Numerous References to the French Codex, 2nd ed. (Philadelphia: Henry C. Lea, 1879), 125-127.
} 
Hops helped relieve dyspepsia, assisted patients to sleep, and could be used in treatments for other ailments like rickets, delirium tremens, and various genitourinary irritations. Along with herbs like chamomile, thyme, and lavender, hops also could be applied topically to relieve pain. ${ }^{77}$ A year later in 1880 , the United States Brewers' Association published a book featuring statements from physicians, chemists, and health officials that supported beer as a harmless, mildly alcoholic beverage with nutritious properties. ${ }^{78}$

The United States Brewers’ Association (USBA) printed several other publications that distinguished beer from other liquors and support it as a temperance beverage. Secretary of the USBA, Gallus Thomann's arguments summarized much of the stance taken by beer advocates. He argued that an increase in the consumption of fermented liquors over distilled liquors directly correlated with the temperance goals of the United States since fermented liquors could be consumed responsibly by temperance advocates, whereas distilled liquors lead to irresponsible inebriation. Thomann also presented studies on the physical and mental effects of distilled versus fermented liquors. In an 1885 argument, he included a chart comparing the percentage of consumption to the percentage of insanity caused by drunkenness in Bavaria and Denmark. The chart shows, and Thomann contended, that the area that consumed less spirits and more malt liquors, i.e. Bavaria, had five times less instances of insanity caused by alcohol. ${ }^{79}$ A year later, Thomann presented the results of a survey comparing death rates and various health

\footnotetext{
77 Ibid., 716-718.

${ }^{78}$ More than one contributor suggested that the use of fermented liquors, meaning beer and light wines, should replace the use of distilled spirits. Salem, Beer, Its History, passim, 128-150.

${ }^{79}$ Gallus Thomann, Liquor Laws of the United States: Their Spirit and Effect (New York: N.Y. Economical Printing Co. for the United States Brewers’ Association, 1885), 231-244.
} 
factors such as liver disease and obesity of men working in breweries with those outside of the industry. He concluded that, despite drinking large amounts of malt liquors, these men "[lived] longer and [preserved] their physical energies better than the average workman of the United States.”80

In response to publications like Thomann's and vocal in public health debates, the American Medical Association (AMA) joined in the discussion on the medicinal properties and uses of alcoholic beverages in 1891 with the formation of the American Medical Temperance Association (AMTA). Established at the AMA's annual meeting, the AMTA's main objective was to study the uses and effects of alcohol from "a purely scientific point of view, above all present theories.” The organization began with apparent anti-alcohol leanings. AMTA members had to pledge total abstinence from alcoholic beverages as a means of securing clear and impartial studies, since "the literature on the subject presents many examples of dangerous and faulty theories, honestly defended by moderate drinkers, who are unable constitutionally to reason logically in this field." ${ }^{81}$ The AMTA, therefore, did not support drinking in moderation as a substitute for heavy drinking.

In the May 13, 1893 edition of The Journal of the American Medical Association, the AMA discounted the bulk of available literature on the uses and abuses of alcohol,

\footnotetext{
${ }^{80}$ Gallus Thomann, The Effects of Beer upon Those Who Make and Drink It, A Statistical Sketch (New York: The United States Brewers’ Association, 1886), 20-21.

81 T.D. Crothers, "Historical Sketch of the American Medical Temperance Association," The American Medical Temperance Quarterly 1, no. 1 (July 1893), 8-9.
} 
calling it a "confused medley of statements by the most incompetent persons." ${ }^{82}$ They deemed it essential for medical professionals to investigate the uses and abuses of alcohol and present them in a professional setting while abstaining from drinking themselves. ${ }^{83}$ By the first issue of The American Medical Temperance Quarterly in July 1893, the editors and main officers in the AMTA clearly supported removing alcohol from the medical profession altogether and multiple articles discredited the medicinal uses of alcohol. Dr. John Harvey Kellogg, the chairman of the Committee of Statistics and chief medical officer at the Battle Creek Sanitarium in Michigan, went so far as to associate alcohol with "poison habits” like morphine, cocaine, and chloral hydrate addictions. ${ }^{84}$ The medical profession remained divided on the uses of alcohol as medicine into the twentieth century, and both beer and anti-alcohol advocates cited physicians and pharmacists who favored their cause.

Perhaps the most politically significant defense the beer industry could levy against legalized prohibition was its contribution to the local and federal governments through taxes and license fees. Liquor taxes "created an air of legitimacy about the trade" that placed liquor industries in respectable positions in the government's eye. ${ }^{85}$ Beer, wine, and distilled liquors together generated between 20 and 40 percent of the nation's

\footnotetext{
82 "Medical Temperance Association," The Journal of the American Medical Association 20, no. 19 (May 13, 1893): 540-541.

${ }^{83}$ The AMTA met at the annual meetings for the AMA until it merged with the American Association for the Study and Cure of Inebriety in 1904. The Bulletin of the American Medical Temperance Association began publication in 1893.

${ }^{84}$ J.H. Kellogg, "Historical Sketch of the American Medical Temperance Association," The American Medical Temperance Quarterly 1, no. 1 (July, 1893), https://babel.hathitrust.org/cgi/pt?id=mdp.39015069890856;view=1up;seq=7 (accessed May 15, 2017), 22. ${ }^{85}$ Hamm, Shaping the Eighteenth Amendment, 96-97.
} 
total tax revenues between 1873 and $1916 .{ }^{86}$ One statistic showed that brewers alone paid an estimated \$1.2 billion to the United States Treasury between 1863 and $1909 .{ }^{87}$ In a bold move, liquor interests supported a bill in 1884 that would make it illegal for states to prohibit the manufacture and sale of commodities subject to federal internal revenue taxes. John Jay Kleiner, a Democrat from Indiana, introduced the bill, but it failed to go beyond the Committee of Ways and Means. Regardless, the liquor interests continued to champion their relationship with the federal government. ${ }^{88}$ As long as the federal tax legitimized alcoholic beverages and the liquor industries continued to thrive, the prohibitionists could hardly expect to eradicate the production of those beverages, much less their consumption. Such was the argument.

The beer industry's relationship to the federal government owed in large part to the most organized and active pro-beer organization prior to National Prohibition, the United States Brewers' Association (USBA). The USBA formed in response to the Internal Revenue Act of 1862 and grew to represent the beer industry in all manner of social and political debates. With the act came a one-dollar federal tax per barrel on all beer sold and a license fee for individual brewers. The tax and fee were in addition to state and local taxes and fees. Until this time, American brewers did not have a strong representation in the federal government. Alarmed by the increased taxes, on August 21,

\footnotetext{
${ }^{86}$ Federal liquor taxes did not remain constant. The liquor tax increased when the federal government needed to increase internal revenue. Two examples provided by historian Richard F. Hamm are the depression in the 1890s and the outbreak of World War I. Hamm, Shaping the Eighteenth Amendment, 9596.

${ }^{87}$ Fox, “The Prosperity of the Brewing Industry,” 55.

${ }^{88}$ Congressional Record: Containing the Proceedings and Debates of the Forty-Eighth Congress, First Session, Vol. 15 (Washington, D.C.: Government Printing Office, 1884), 701. Hamm, Shaping the Eighteenth Amendment, 97.
} 
1862, a group of brewers met in New York City to form a representative coalition which became the USBA. ${ }^{89}$

The USBA quickly became a significant force in the beer industry. Reasonably argued in a 1901 history of the American brewing industry, "to write in detail the history of the United States Brewers’ Association would be virtually to cover the history of the industry since 1862." 90 Not only did USBA representatives lobby on behalf of the beer industry in the political arena, but they also confronted attacks on the industry. The USBA printed a wide-range of material concerning everything from the science and technology of brewing to political, social, and health concerns. At first, only German lager brewers from the East Coast made up the USBA, but Western and ale brewers were soon incorporated, as well as auxiliary industries. ${ }^{91}$ Ultimately, the efforts of beer industry representatives to work with local and national governments proved sufficient in the face of the early anti-alcohol movements.

In the late nineteenth century, the Prohibition Party, WCTU, and other temperance groups achieved marginal success in securing prohibition legislation at the

\footnotetext{
${ }^{89}$ The 1862 meeting consisted of brewers working in New York City and the nearby area. John N. Katzenmayer proposed the meeting with the intention to eventually form a national federation of brewers and related trades. Katzenmayer expressed the need to have an organization to protect common interests and ensure that the tax law was being obeyed. As the organization grew, it continually diversified to include affiliated industries and different types of brewers from various backgrounds. Within ten years, the USBA membership included brewers from across the nation. One Hundred Years of Brewing, 226. ${ }^{90}$ Ibid., 242.

${ }^{91}$ Baron, Brewed in America, 213-218. Kerr, Organized for Prohibition, 27-28. The USBA extended membership opportunities to the Pacific Coast brewers at the Thirteenth Convention in 1873. One Hundred Years of Brewing, 232. For example, Henry Weinhard of Portland, Oregon was nominated as a vicepresident to assist with the proceedings of the USBA's seventeenth convention in 1876. United States Brewers' Association, Documentary History of the United States Brewers' Association, Part II (New York: United States Brewers’ Association, 1898), 458.
} 
state level, but only three attempts at National Prohibition came under consideration. In 1876, Republican Representative Henry W. Blair of New Hampshire presented the first prohibition bill to amend the U.S. Constitution. The bill aimed at distilled liquors only, but Republican Senator Preston Plumb of Kansas introduced a stronger amendment concerning “all distilled and fermented liquors as a beverage” in $1880 .{ }^{92}$ Both amendments did not go beyond committee consideration. In 1887, Blair, then a senator, presented a third amendment. WCTU president Frances E. Willard, national chairman of the Prohibition Party John B. Finch, and secretary of the National Temperance Society John N. Stearns drafted the amendment. It went to a vote on March 2, 1889, but it failed to pass. The next prohibition amendment brought before Congress would not surface until 1914. ${ }^{93}$

While multiple factors contributed to the failure of the early attempts at passing a national prohibition law, the federal liquor tax was the most significant factor. The tax presented a formidable obstacle to those in favor of prohibition. Revenue raised from taxes on alcohol, at least as it concerned the Internal Revenue Office, simply overruled any objections to the liquor industries. Interestingly, brewers and other liquor producers located within prohibition states purchased federal liquor licenses and paid federal taxes. To the prohibitionists' frustration, it became the official stance of the Internal Revenue Office in the 1880 s to refuse requests to testify against potential illegal liquor operators

\footnotetext{
92 “National Prohibitory Constitutional Amendment," Sixteenth Annual Report of the National Temperance Society and Publication House (New York: The National Temperance Society and Publication House, 1881), 38-39.

${ }^{93}$ Caswell reported the votes at 19,172 against and 7985 in favor of the law, or a ratio of thirty-three to thirteen votes against. John E. Caswell, “The Prohibition Movement in Oregon: Part 1, 1836-1904,” Oregon Historical Quarterly 39, no. 3 (Sept. 1938): 260-261.
} 
and salespersons or produce license or tax logs in court cases. The argument until at least the twentieth century went that the federal government would leave prohibition enforcement to the states. In addition to the taxes themselves, the practice of regulating liquor sales and collecting taxes helped establish relationships between liquor producers and government employees. Temperance advocates saw the need for federal tax reform early on, but it would take until the 1910 s for such reform to go into effect. ${ }^{94}$

By the mid-1890s, temperance reform faltered, and the movement suffered. In 1889, the Dakotas were the last of seven states to adopt prohibition prior to the twentieth century. However, by 1903, only Maine, Kansas, and North Dakota maintained statewide prohibition. Saloons and liquor dealers continued to operate in dry areas. Interstate commerce between wet and dry areas presented still more problems. ${ }^{95}$ This was due at least in part to the generally weak political ties between the Prohibition Party and state officials, but law enforcement also proved more difficult than expected. Moreover, the economic and political clout of brewers and saloon owners thwarted much of the antiliquor initiatives. ${ }^{96}$

By the mid-1890s, factions and general disorganization in both the Prohibition Party and the WCTU left temperance advocates in need of a stronger representative organization. ${ }^{97}$ A group of temperance reformers from Ohio answered the need with the

\footnotetext{
${ }^{94}$ Hamm, Shaping the Eighteenth Amendment, 92-119.

${ }^{95}$ The contemporary literature often used the terms "wet" and "dry" to distinguish people or places that allowed alcohol versus those that did not, respectively.

${ }^{96}$ Baron, Brewed in America, 217, 272-273. Dunlop, Portland Beer, 39. Powers, Faces Along the Bar, 1518.

${ }^{97}$ Both the Prohibition Party and the WCTU struggled against national economic concerns, questions about how to operate in the changing political arena, financial issues, and leadership deficiencies. Hamm, Shaping the Eighteenth Amendment, 123-128.
} 
creation of the Anti-Saloon League of America (ASL). The ASL redefined, reorganized, and dominated the Temperance Movement from 1895 into the 1920s. Instead of targeting state and national levels of government with radical goals at the outset, the ASL and the twentieth-century temperance advocates promoted moderate goals at the local level with the intention to gradually evolve into national reform, a process that political scientist Ann-Marie Szymanski termed "local gradualism." ${ }^{98}$ At the turn of the twentieth century, beer advocates faced local option laws that threatened their most lucrative public drinking establishment, the saloon. At the same time, Americans grew more concerned with the purity of their food and beverages. What followed was a campaign for the beer industry to meet distribution limitations while further supporting an image of purity and wholesomeness.

${ }^{98}$ Ann-Marie Szymanski, Pathways to Prohibition: Radicals, Moderates, and Social Movement Outcomes (Durham, NC: Duke University Press, 2003), 5. 


\section{Chapter 2}

The Defense of Pure Beer and the Saloon Problem, 1896-1906

"There are bad men in the liquor traffic and always have been, just as there are bad men and always have been in other callings ... The wholesale denunciation of saloon-keepers is unjust, irrational, and illogical in the extreme. There is nothing in the history of our country to justify it. On the contrary, the impartial critic will be compelled to admit that at all times the properly conducted tavern, ordinary or saloon proved a center of influences which tend to the elevation rather than the degradation of the people.”

- Gallus Thomann, Secretary of the United States Brewers’ Association, $1906{ }^{99}$

"The brewers tell us in their journals that beer is a substitute for the hurtful drinks, wine and whiskies. As a last resort the brewers and the others fall back upon the assumption that men will drink, therefore the saloon is a necessary evil - but an evil all the same ... It is the public licensed place for making drunkards out of those who were made in the image of God.”

- David O. Mears, President of the Ohio Anti-Saloon League, $1894^{100}$

The Midwest offered an ideal environment for nineteenth-century saloon culture.

Cities like Chicago and St. Louis were transportation hubs for the railroads, and countless goods traveled through the cities on their way across the country. Merchants had easy access to livestock, grain, and vegetables from the Western and Midwestern states. With the ease of transportation and proximity to resources, various industries fueled the region. Laborers migrated there to work in those industries, and they brought their drinking habits with them.

\footnotetext{
99 “An Excellent Argument: Mr. Thomann’s Argument,” The Western Brewer: and Journal of the Barley, Malt, and Hop Trades 31, no. 4 (April 1906), 200.

100 The Haskell Bill was a local option bill presented to the Ohio House of Representatives. The Ohio AntiSaloon League campaigned in its favor. "An Eloquent Plea, The General Assembly Appealed to in the Interest of the Haskell Bill, Address by Rev. David O. Mears, D. D., President of the Ohio Anti-Saloon League, at the Hearing of the House Committee on Temperance at the State House, Columbus, Ohio, March 22, 1894,” Anti-Saloon 1, no. 5 (March 1894), 2.
} 
The tradition of providing food alongside alcohol stemmed from the colonial period with taverns and inns. Saloonkeepers in the late nineteenth century added a twist to that tradition. Receiving negative attention from the temperance community, especially in the decades following the Civil War, saloonkeepers began offering complimentary food with drink purchases. This practice varied region to region, largely depending on food prices and availability, the cost of liquor licenses, and laws regulating food within saloons. However, free lunches with drink purchases became a common tenant of the saloon culture. Workingmen had better luck finding a good meal in a saloon than anywhere else. Saloonkeepers made contracts with food suppliers and acquired quality foods at much lower prices than the average worker, often making the free lunches more agreeable than meals cooked at home or purchased in affordable restaurants. ${ }^{101}$ When considering that the price of a glass of beer, and thus lunch, tended to be five cents in most cities, saloons quickly became significant distributors for breweries. ${ }^{102}$ Saloons played significant roles in everyday life, especially for the working classes. ${ }^{103}$

Chicago provides a good example of a city receptive to saloons. Fraternal lodges with dues-paying members often held meetings in auditoriums above or near saloons. Several saloons occupied the bottom floors of large brick buildings while the remaining floors served as meeting rooms or convention halls. Brewing companies or private liquor dealers typically owned these places and offered cheap rent for fraternities or social clubs

\footnotetext{
${ }^{101}$ Royal L. Melendy, “The Saloon in Chicago, II,” American Journal of Sociology 6, no. 4 (Jan., 1901), 433-464.

102 Madelon Powers, Faces Along the Bar: Lore and Order in the Workingman's Saloon, 1870-1920 (Chicago: The University of Chicago Press, 1998), 207-226.

103 Perry R. Duis, The Saloon: Public Drinking in Chicago and Boston, 1880-1920 (1983; repr., Urbana, IL: Illini Books, 1999), 8.
} 
to meet. In 1901, five convention halls were located within a 2.5-mile segment of Milwaukee Avenue, the main thoroughfare for the western working-class district. A fourmile segment of Madison Street running from the lake, through the business district, and into the working-class district, offered 115 saloons and 53 restaurants. ${ }^{104}$ Saloons in most towns or cities around the country harbored characteristics of their neighborhood and catered to their regulars. ${ }^{105}$

While Chicago provided the physical and social infrastructure for saloons, it also provided the beer. Near major brewing cities like St. Louis and Milwaukee, Chicago saloons sold the national brands of beer alongside their local fare. The Midwest hosted a large concentration of nationally-known breweries with roots going back to the antebellum years. German immigrants founded several communities in cities like Chicago, Milwaukee, St. Louis, and Detroit. Names like Anheuser-Busch, Pabst, Miller, Schlitz, Blatz, and Stroh graced billboards, saloon windows and entranceways, and newspaper advertisements.

As mentioned in the previous chapter, a general anti-saloon sentiment existed among temperance reformers, and this continued into the twentieth century. One popular example, prohibitionist Upton Sinclair published his novel, The Jungle, in 1906 dramatizing the plight of an immigrant family living in the meat-packing district of

\footnotetext{
${ }^{104}$ Melendy, “The Saloon in Chicago, II,” 433-464.

${ }^{105}$ Historian Madelon Powers defined "regulars" in saloons as those who frequented a location, purchased drinks on a regular-basis, conformed to the written and unwritten laws of barroom drinking, were reasonably behaved, and shared some common ground with the established clientele. Usually, the regulars of a saloon shared an occupation or ethnic link. The idea of a regular meant that saloons operated as both public and semi-private institutions. While strangers were not typically turned away, they were not immediately given access to the "club” aspect of the establishment. Powers, Faces Along the Bar, 19-21.
} 
Chicago, informally called Packingtown. The narrative followed the unfortunate trials of a group of Lithuanian immigrants as they attempted to find their way in a new country. Sinclair novelized the desire for the workers in Packingtown to escape the monotonous, yet grueling, work by patronizing the local saloons. He described the appeal of the saloons as warm and welcoming, with enticing names and décor, providing hot meals and places to relax and socialize. Offering a stark change from their working conditions and, in many instances, their living conditions, Sinclair's saloons appeared as wolves in sheep’s clothing. He described systems of competition and persuasion that inevitably drained the working men of their wages, time, health, and mental faculties. In Sinclair's view, saloonkeepers strategized means to bring patrons inside and to keep them there, regardless of their well-being or their familial obligations. ${ }^{106}$

Sinclair's objections to saloons in The Jungle echoed many of his fellow prohibitionists, but his book proved more influential in another social reform movement, the Pure Food Movement. By the time he published his book 1906, a decade of the antisaloon had passed and wards, towns, cities, counties, and even some states had laws banning saloons. The dominant forces in the Temperance Movement were attempting to solve the alcohol problem by squashing the saloon culture. With deep connections to the

\footnotetext{
${ }^{106}$ The Jungle began at a wedding party in the backroom of a saloon, and saloons made several other appearances throughout the novel. Upton Sinclair, The Jungle (New York: Doubleday, Page \& Company, 1906), especially 95-96.

Sinclair witnessed the effects of alcoholism early on in his life. He wrote a book that acted as both an autobiography and biography in the 1950s, retelling his personal disdain for alcohol and the "tragic record of a half-century of American genius, twisted and tortured by alcohol." He recounted his own experiences and those of several close friends with alcohol, beginning before National Prohibition. Among stories and personal insight, Sinclair offered support for Alcoholics Anonymous and hope for those struggling with alcoholism. Upton Sinclair, The Cup of Fury (Manhasset, NY: Channel Press, Inc., 1956), quote on page 18.
} 
saloon culture and the immigrant and working classes, the beer industry responded to threats from both the Pure Food and Temperance movements.

The limited success in securing prohibition legislation and ultimately solving America's liquor problem in the 1880s and early 1890s did not deter members of the Temperance Movement. They simply changed tactics from focusing on radical prohibition legislation and moral pressure to implementing local gradualism and increasing political pressure. ${ }^{107}$ Essentially, temperance leaders made the elimination of the saloon and other public drinking areas the main objective of the anti-alcohol campaign, while making private drinking habits a secondary focus. Anti-saloon sentiment grew as the saloon culture became more ingrained in the United States. ${ }^{108}$ Championed by a new organization, the Anti-Saloon League (ASL), temperance advocates from the mid-1890s onward largely supported a different anti-alcohol weapon: local option.

\footnotetext{
${ }^{107}$ Political scientist Ann-Marie Syzmanski used the term "local gradualism" to describe the tactic of first prohibiting alcohol at the local level and gradually moving towards national prohibition. Ann-Marie Szymanski, Pathways to Prohibition: Radicals, Moderates, and Social Movement Outcomes (Durham, NC: Duke University Press, 2003), 5.

Historian Peter Odegard classified the Anti-Saloon League as a "pressure group.” In other words, the ASL was a minor association that, "without regard for party opinion on other matters, [carried] on agitation for or against projects deemed favorable or prejudicial to their interests." The League was not the only pressure group of its kind but, in relation to the Temperance Movement and National Prohibition, it was arguably the most powerful. Peter H. Odegard, Pressure Politics: The Story of the Anti-Saloon League (New York: Columbia University Press, 1928), vii-viii.

${ }^{108}$ Historian Perry Duis based his study on public drinking in Chicago and Boston on the spatial divisions of urban areas into three basic types: public, private, and semipublic. The result of more urban-living was crowding and an increased desire to spend time in public and semipublic places. He noted that the growth and variety of semipublic places in urban areas contributed to concerns of social control. Duis' research detailed the pre-Prohibition saloon as a semipublic institution and compared saloons and saloon culture between the two cities. Duis, The Saloon, 3-6.
} 
Anti-saloon advocates found political, economic, and social value in local option laws. Said laws gave voting citizens within specific jurisdictions the chance to outlaw the sale of alcohol. ${ }^{109}$ Without being able to sell alcohol, Leaguers and their supporters argued, the saloons would have to close and, thus, benefit the dry communities. Antisaloon advocates argued that alcohol use drained tax revenue with the increase in drunkards and funding of poor houses, hospitals, asylums, and orphanages. Also, alcohol use hindered production and accuracy in the workplace. To them, forbidding the sale of alcohol increased workplace efficiency and production since workers would not be inebriated or ill from drinking alcohol. Moreover, the economy would receive a boost by redirecting income otherwise spent on alcohol to local businesses, and the working class would theoretically be able to purchase new technologies, products, and services. Furthermore, time once spent in the saloon could be redirected towards other, more wholesome, leisure-time activities, such as traveling, visiting theaters, and playing games. ${ }^{110}$ Ideally, through local option, enough dry areas would inspire more stringent prohibition legislation, with the end-goal being a national prohibition law. ${ }^{111}$ Thus, local

\footnotetext{
${ }^{109}$ Richard F. Hamm, Shaping the Eighteenth Amendment: Temperance Reform, Legal Culture, and the Polity, 1880-1920 (Chapel Hill, NC: The University of North Carolina Press, 1995), 28.

It is significant to note that those without voting rights or equal access to elections could not vote on local option. In other words, women, non-citizens, and, in many places across the nation, AfricanAmericans and other races and ethnicities were sometimes not considered "voting citizens" in local option elections. While women organized in highly publicized groups such as the WCTU, it is difficult to locate material representing minority groups that specifically address local option, temperance, or prohibition during this period.

${ }^{110}$ Louis M. Hacker, "The Rise and Fall of Prohibition,” Current History 36, no. 6 (Sept. 1, 1932), 662663. "The Local Option Law,” Oregon Historical Society Research Library.

Automobile manufacturer, Henry Ford was a vocal supporter of prohibition. He was quoted as saying, "All the energy put into the breweries of Michigan and the breweries themselves can be turned into good use.” Quoted in “As the Year Opens,” The Temperance Cause 38, no. 11 (Jan. 1917), 89.

${ }^{111}$ Odegard, Pressure Politics, 47-48, 116-125.
} 
option laws were not prohibition laws outright but a means to battle the saloons in areas where the citizens deemed saloons should not exist. ${ }^{112}$

While several temperance groups held contempt for saloons in general, including the Prohibition Party and the Woman's Christian Temperance Union (WCTU), the most influential group in securing local option was the Anti-Saloon League (ASL). The ASL and other prohibitionists promoted the doctrine of "home rule" inherent in local option laws. In general terms, home rule meant that voting citizens of a specified political unit could self-govern, at least on matters like liquor licenses. ${ }^{113}$ Even those not affiliated with the ASL or other anti-saloon groups supported local option on the basis that it did allow communities to self-govern and, thus, exercise their democratic privileges. ${ }^{114}$

The ASL first formed in Columbus, Ohio in 1893 and became a national organization the following year. Speakers at the 1894 Annual Congress bemoaned the crime, disease, and domestic distress brought on by intemperate behavior in the United States. Reverend John A. Watterson, Bishop of Columbus, lamented that saloons corrupted the young men seeking work in large towns and cities and turned them into

\footnotetext{
112 To some citizens, supporting local option meant providing protection for the community against saloons and supposedly associated evils. Ibid.

Local option passed in Oregon in 1904, and Dr. G.L. Tufts of Portland wrote that it would "be the salvation of this state.” G.L. Tufts, "Local Option," "Oregon - Laws and Legislation - Local Option," Vertical File, Oregon Historical Society Research Library.

${ }^{113}$ Hamm, Shaping the Eighteenth Amendment, 12-13. Szymanski, Pathways to Prohibition, 3-4. Local option committees formed in different locations around the United States. In Oregon, the Citizens Local Option Committee for Multnomah County argued that "the local option idea is the putting into effect the American Doctrine of Home Rule. It gives the people in the smallest legal subdivision of the state the largest possible control of the liquor traffic therein. It affords the resident portion of our cities and the rural districts what has been proved to be a practical protection against the saloons.” The committee renamed itself shortly after this address was written. "The Local Option Law, An Address to the voters of Multnomah County, from the Business Men's Committee," "Oregon - Laws and Legislation - Local Option,” Vertical File, Oregon Historical Society Research Library.

${ }^{114}$ Odegard, Pressure Politics, 119.
} 
poor, miserable drunkards. He asked in his address, "Strangers in a strange place, how are these young men to spend their time when not at work? ... Saloons abound everywhere, and everywhere they are open and cheerful looking, with their bright lights in summer and their warm fires in winter." 115 In his address, Rev. Watterson employed a metaphor for approaching the saloon "as the Yankee did with the bed-bug.” “" I have no special feeling,'” the Yankee said, “'against the bed-bug in himself. The bed-bug as a bug is good; but I do dislike the way he makes his living." " ${ }^{116}$ He suggested, and the ASL in general adopted a similar sentiment, that the best way to remedy the growing consumption of alcohol was three-fold: educate the masses to the harms of alcohol, diminish the number of saloons and regulate the remaining ones, and discourage saloon customers "by the creation of a sound individual and public conscience.”117 Gradually, the removal of saloon culture would theoretically decrease alcohol dependence.

The ASL was a league of churches and temperance societies that operated as a distinctly non-partisan organization. While mostly comprised of white, Protestant churches, the League did not limit membership to specified denominations or religions. Even though Republican-leaning in many respects, the League worked through the dominant parties within an area to achieve alcohol regulations like local option and high licenses. Membership in the League and internal committees included both Democrats

\footnotetext{
115 John A. Watterson, Washington Gladden, Levi Gilbert, and John G. Woolley, “Unity, Persistency, Victory!" A Souvenir Selection of the Anti-Saloon Addresses Delivered at The Annual Congress of the Ohio Anti-Saloon League At Columbus, December 11-13, 1894 (Columbus, OH: The Ohio Anti-Saloon League, Hann \& Adair, 1895), 7.

116 Ibid., 8.

${ }^{117}$ Ibid., 9-10. S.E. Nicholson, "The Local-Option Movement,” The Annals of the American Academy of Political and Social Science 32 (Nov. 1908), http://www.jstor.org/stable/1010546 (accessed May 13, 2017), 3-4.
} 
and Republicans. ${ }^{118}$ Unlike a political party that had to attend to multiple issues, the ASL focused attention on prohibition and the means to achieving it. They avoided direct involvement in other issues, which contributed to the effectiveness of their campaigns. ${ }^{119}$

The founder of the ASL, Howard Hyde Russell, believed he was ordained by God to champion the temperance cause and eliminate the saloons. In a speech delivered at the fifteenth annual convention in 1913, Russell told the story of how he escaped the "jaws of destruction" as a young man and vowed to "go out to [his] brethren in the churches and to plead with them to lay aside their differences upon other questions and come together in a never-ending war on behalf of suffering humanity until the cause of such tragedies as this shall be put away forever." ${ }^{120}$ A former lawyer in Iowa, Russell graduated from the seminary at Oberlin College in Ohio. Afterwards, he served as a minister in the stockyard districts of Kansas City and Chicago before returning to Oberlin in 1893 where he founded the Ohio branch of the ASL. Russell served as the national league's superintendent until resigning in 1903. Methodist minister Purley Baker succeeded Hyde as national superintendent and served until his death in 1924. Both men were effective leaders and public-speakers and helped influence the passage of local option laws nationwide. ${ }^{121}$

\footnotetext{
118 Odegard, Pressure Politics, 81-82. Historian Richard Hamm also described the ASL as bureaucratic, secretive, opportunistic, and pragmatic. Hamm, Shaping the Eighteenth Amendment, 129-131. ${ }_{119}$ Odegard, Pressure Politics, 15-18. K. Austin Kerr, Organized for Prohibition: A New History of the Anti-Saloon League (New Haven: Yale University Press, 1985), 6-8. ${ }^{120}$ When passing by the Rochester Brewery in Kansas City, Russell said, "Always when I passed this devil's-broth factory I prayed God to stay the tide of sin and shame flowing therefrom." Quoted in Odegard, Pressure Politics, 6-9.

${ }^{121}$ K. Austin Kerr, "Russell, Howard Hyde (1855-1946)," in Alcohol and Temperance in Modern History: An International Encyclopedia, eds. Jack S. Blocker, Jr., David M. Fahey, and Ian R. Tyrell (Santa Barbara, CA: ABC-CLIO, Inc., 2003), 2:528-529.
} 
The fragility of local option laws in stamping out the saloons soon became apparent to prohibitionists. The designation of political units contributed to the problem. For example, if several counties within a state voted to prohibit the sale of liquor licenses, but those counties did not hold the majority of the state's population, then securing statewide prohibition proved challenging. As states started allowing municipalities to vote independent of the counties, saloons reopened in select cities and towns within dry counties. Even though large physical areas around the country operated under local option laws, most of the population was concentrated in areas selling liquor licenses and housing saloons. ${ }^{122}$

The relationship between brewers and saloons was common knowledge, and antisaloon sympathizers targeted brewers for it. An article from the prohibition-leaning newspaper, The Kansas City Star, nicely summarized the sentiment: "The aim of the brewery to-day is not what it was a few years ago - to make beer and sell it. Now it's to make beer, open and conduct saloons, own saloon licenses, own saloons, own saloon property, take all the profits, fight every attempt to keep saloons out of residence districts and defend every saloon keeper who gets into trouble in his place of business." ${ }^{123}$ As the anti-saloon campaign waged on, beer industry advocates found it increasingly difficult to appeal to the American public as a law-abiding and viable industry.

\footnotetext{
122 Odegard, Pressure Politics, 119-121.

123 "Brewer as Saloon Keeper: Both Profits are Taken by the Beer Makers Nowadays," The Kansas City Star, March 10, 1905.
} 
The beer industry responded to anti-saloon sentiment by boosting alternative ways to access their product outside of saloons. Beer sold in groceries, hotels, and restaurants already, but breweries increased home-delivery efforts and promoted family-friendly beer gardens to bolster a wholesome image. An increase in beer-bottling allowed breweries to fill individual orders and sell to street vendors. ${ }^{124}$ At least until legislation passed in 1913 forbidding it, brewers maintained a presence in dry areas by shipping their product between states. ${ }^{125}$

Beer industry advocates also took an offensive stance to argue that enforcing prohibition was impractical. They argued that absolute prohibition was ridiculous, since there was no way to stop people from drinking alcohol, and law enforcement officials simply did not have the ability to enforce that level of control. General counsel for the United States Brewers’ Association (USBA), Robert Crain said, “One of the faults of prohibition ... is that it hugs the insane delusion that the body politic can be prevented from drinking in any form." Instead of having licensed, tax-paying establishments serve alcohol, he argued that prohibition would create incentive for locations to sell alcohol illegally. These places already existed in areas under local option laws, often called "blind tigers” or "speakeasies.” To Crain, prohibition promoted corruption, threatened livelihoods of industry employees, and took away from the earning potential of the department of internal revenue through taxes and legal licensing. ${ }^{126}$

\footnotetext{
${ }^{124}$ Duis, The Saloon, 64-67.

${ }^{125}$ Hamm, Shaping the Eighteenth Amendment, 208, 212-220.

126 "Against 'Blind Tigers,'” The Western Brewer: and Journal of the Barley, Malt and Hop Trades 31, no. 3 (March 1906), 137. What is more, it was not uncommon for members of law enforcement to own or invest in saloons. Portland, Oregon's police chief for much of the 1870s and early 1880s, for example,
} 
Another social reform movement at the turn of the twentieth century threatened

the beer industry, but it did so by making the beer itself out to be impure and detrimental

to one's health. While the ASL campaigned against saloons and breweries, members of

the Pure Food Movement defended American families against tainted, or adulterated,

food. ${ }^{127}$ Their early success culminated in passing a federal law in 1906 with the Pure

Food and Drug Act. The beer industry had defended pure beer for decades, and advocates

responded to this movement by touting breweries as modern and sanitary spaces. They

sold beer as a pure and wholesome beverage made under state-of-the-art conditions.

Several brewers publicly supported the pure food cause and fit their products within a

healthy, morally acceptable American diet. ${ }^{128}$

As mentioned above, Americans recognized Upton Sinclair's The Jungle for more

than his descriptions of the saloon culture or immigrant troubles. Massive public attention

owned the Oro Fino saloon and theater. Another Portland saloonkeeper, Edward Chambreau, later recalled, "The first thing I did when I took charge of the 'Hell Hole' [meaning his saloon] was to fix the policeman on my beat." Carl Abbott, Portland in Three Centuries: The Place and the People (Corvallis, OR: Oregon State University Press, 2011), 45.

127 "Adulteration" was the common term used to imply "an altering that is fraudulent and injurious, $-\mathrm{a}$ tampering that, in the case of food, either cheats the consumer out of a part of his money, deprives him of a portion of the nutriment or the satisfaction he has a right to expect, or, worst of all, actually undermines his bodily health, and poisons by what should nourish and strengthen.” S. W. Johnson, "Adulterations in Food," Journal of Social Science 13 (Mar 01, 1881),

http://stats.lib.pdx.edu/proxy.php?url=http://search.proquest.com.proxy.lib.pdx.edu/docview/1296588519? accountid=13265 (accessed March 30, 2017), 100.

Other definitions for "adulteration" exist across time and place, but, as Bee Wilson summarizes in her history of "food cheats," adulteration laws consistently guarded against poisoning and cheating. From there, what was considered poisonous or a dishonest disclosure of ingredients was determined by those interpreting and enforcing the law. Wilson writes from a primarily British perspective, but her history includes America's relationship with food adulterants from its beginnings to the twenty-first century, often comparing American and European experiences. Wilson, Swindled, xii.

${ }^{128}$ Stanley Baron, Brewed in America: A History of Beer and Ale in the United States (Boston: Little, Brown, and Company, 1962), 291-292. The brewers, wholesale liquor dealers, and distillers also used purity and adulterations in their arguments against one another. Duis, The Saloon, 78-79. 
motivated many Americans to raise concerns about the purity of industrially produced foods. ${ }^{129}$ The graphic descriptions of the poor living and working conditions of the residents of Packingtown accompanied the grossly impure food produced there and sold to unassuming consumers. Within a year of its release, the United States Congress passed the Pure Food and Drug Act. The Jungle, however, was far from an introduction to the pure food crisis. The complex process to secure the act took several decades. ${ }^{130}$

Even though adulterations existed well before the Pure Food and Drug Act, the general concern for public health increased as more instances of adulterated foods, beverages, and medicines on the market received attention. Essentially, changes in food production and transportation brought on by industrialization made it more economical to produce foodstuffs on a large scale, at a distance, and out of sight of most consumers. These changes allowed producers and manufacturers to use cheaper substitutes or additives without the consumers' knowledge. ${ }^{131}$ The Pure Food Movement brought

\footnotetext{
129 James Harvey Young, Pure Food: Securing the Federal Food and Drugs Act of 1906 (Princeton, NJ: Princeton University Press, 1989), 221-252.

${ }^{130}$ Historian James Harvey Young credited its passage to seven Cs: change, complexity, competition, crusading, coalescence, compromise, and catastrophe. These concepts outlined the circumstances of American politics, economy, and society during the Gilded Age and Progressive Era that fostered a federal law regulating marketed food, beverages, and drugs. Essentially, Young argued that the "research revolution" of this era increased scientific investigations in the quality of substances being consumed, and public awareness of these findings along with proven and alleged cases of illnesses resulting from adulterations led people to crusade for regulatory measures. However, pure food advocates had to compromise with business interests and marketplace competition motivated by substitutes and cheaper ingredients. To complicate the process even more, different businesses sponsored bills that benefited them at the expense of their competition. Coalitions of professionals, women's club members, and other reformminded individuals increased crusading efforts despite failed compromises within Congress. According to Young, it was catastrophe brought forth by the vivid descriptions of horrors associated with the meatpacking industry in Upton Sinclair's novel The Jungle that finally garnered enough public support to push the food and drug law through. Young, Pure Food, 4-6. Upton Sinclair, The Jungle.

${ }^{131}$ Young, Pure Food, 3-4. J.T. Pratt, author of Food Adulteration, wrote in 1880 that the United States was the only "enlightened" nation to not have laws protecting its citizens against impure and poisoned food, to "check the practice of food adulteration." A large reason for a lack in legislation was due to the American political debate of states' rights versus federal power and where one jurisdiction ends, and the
} 
together individual citizens and professionals from various fields to research and expose such adulterations and to propose legislation to protect citizens from them. ${ }^{132}$ When the first National Pure Food and Drug Congress met in 1898, members from the food and drug trades, agriculturalists and farmers, representatives from multiple levels of government, and professional and trade associations attended. Middleclass businessmen and professionals represented the several trades and professions that food and drug laws directly influenced. ${ }^{133}$

Arguably the most vocal representative of the Pure Food Movement within the federal government was the American chemist and physician, Harvey Washington Wiley. In 1883, Wiley became the head of the U.S. Department of Agriculture's Division of Chemistry. He served in this role until his resignation in 1912. He often spoke and wrote on food and drug adulterations and promoted public awareness of the issues at hand. ${ }^{134}$ He argued that "sanitation is principally a chemical problem: pure food, pure drugs, pure air, pure water, insuring pure activity of mind and body, curing disease by evading it and prolonging, by many years, the most valuable part of human life, viz., its period of

other begins. As with the debates on prohibition legislation, pure food advocates involved themselves in this debate. J.T. Pratt, Food Adulteration: or, What We Eat, and What We Should Eat! (Chicago: P.W. Barclay \& Co., 1880), viii. Bee Wilson, Swindled: From Poison Sweets to Counterfeit Coffee - The Dark History of the Food Cheats (London: John Murray, 2008), 152-153.

132 George T. Angell of Boston was a philanthropist and one of the first American animals' rights activists. He also investigated food adulterations. He read papers, wrote, and gave speeches on the subject. He spoke at the annual meetings of the American Social Science Association in 1879, 1880, 1881. The paper he read at the 1879 annual meeting, titled "The Manufacture and Sale of Poisonous and Dangerously Adulterated Articles” was very popular at the meeting and mentioned in future meetings. However, the paper was not published. The subsequent speeches were published. There, he described the adulterants in oleomargarine and glucose. He cited cases where "free sulphuric acid" or "oil of vitriol” and lime were found in glucose. He claimed that brewers often used glucose in the brewing process. George T. Angell, "Remarks of Mr. Angell,” Journal of Social Science 13 (1 Mar 1881), 130-132.

133 Young, Pure Food, 126-130.

134 Wilson, Swindled, 173-178. Harvey W. Wiley, Harvey W. Wiley: An Autobiography (Indianapolis: The Bobbs-Merrill Company, 1930). 
maximum endeavor and accomplishment.” Wiley’s department used chemistry to test for adulterations. When the Pure Food Act needed interpretation, Wiley and his department provided clarification.

Pure food advocates held different interpretations of what foods were pure and should be sold. The Pure Food and Drug Act of 1906 was vague in some of its terminology, so the Division of Chemistry determined what constituted impurities and how the law should be applied. Even though the law itself had some shortcomings, it was a success of the Pure Food Movement and the first federal law in the United States regulating marketed foods, beverages, and drugs. ${ }^{135}$

Much in the same way as those involved in the Temperance Movement, pure food advocates defended the health and well-being within American homes and communities. Membership in the two movements often overlapped, as temperance advocates worked to expose any adulterants found in alcoholic beverages. Members of both movements also tended to be white, middle-class, Anglo-Saxon, Protestants. ${ }^{136}$ Wrapped in the discussions on food purity were links to morality. Wiley himself argued that chemistry improved the morality of man by detecting adulterations and fraud and improving the

\footnotetext{
135 U. S. Food and Drug Administration, "Food Standards and the 1906 Act,” U. S. Food and Drug Administration, https://www.fda.gov/AboutFDA/WhatWeDo/History/ProductRegulation/ucm132666.htm (accessed February 12, 2018).

${ }^{136}$ Commonly, nutritionists and home economists taught “Americanization” through Anglo-Saxon-derived diets. Promoting such diets was one way to normalize a certain population's behaviors over others. Interestingly, by the 1920s, interpretations of what types of foods qualified as "nutritious" increasingly took into account business interests of food manufacturers. Levenstein, Revolution at the Table, 147-160.
} 
morality of trade. ${ }^{137}$ While his focus was on the dangerous materials introduced to foods, beverages, and drugs, temperance and pure food advocates linked certain foods with moral behavior.

As the most basic social building block, experts argued that good individual health promoted good morals and character that helped families and communities confront difficult social issues, including alcoholism. ${ }^{138}$ Individual health was necessarily linked to diet, and positive eating habits began in the home. ${ }^{139}$ While organizations such as the Woman’s Christian Temperance Union (WCTU) invited women nationwide to join in purifying the home of alcohol, it and other social reform organizations insisted that American women needed to be more proactive about health needs within the home. Taking further hold of her sphere of influence begun in previous decades, the "modern housewife” employed similar methods to men in factory settings, with efficient tools and

\footnotetext{
${ }^{137}$ Wiley, Harvey W. Wiley, 252.

${ }^{138}$ Charlotte Biltekoff, Eating Right in America: The Cultural Politics of Food \& Health (Durham, NC: Duke University Press, 2013), 1-12. The two concepts guiding Biltekoff's work are that health is fundamentally a social construct influenced by cultural politics, and dietary ideals were historically inextricable from notions of good citizenship and the social concerns of the middle class.

${ }^{139}$ According to historian Harvey Levenstein, studies in nutrition science, domestic science, and home economics at the turn of the twentieth century revolutionized the American home and diet. Levenstein's study focused on how the changing consumption and food preparation methods in the United States originated and ultimately affected Americans. As the middle class grew in America, so did the application of science and technology in eating and food preparation habits. Nutrition science was a new field that arose in the 1880s and grew from a primary focus in agricultural experimentation to studies in human nutrition. Harvey Levenstein, Revolution at the Table: Transformation of the American Diet (Berkeley, CA: University of California Press, 2003), 45, 59, 73-80.

Nutritional scientists and home economists often worked together as both fields developed around the same time. Home economists promoted economical and efficient food choices while educating Americans on hygiene and food safety. By the turn of the twentieth century, most middle-class high school students across the country had received some form of instruction in both nutrition science and home economics. Embracing advanced learning, students in university-level programs were often required to take sciences such as chemistry, biology, and bacteriology to better understand the underlying processes of proper hygiene and cooking. Helen Zoe Veit, Modern Food, Moral Food: Self-Control, Science, and the Rise of Modern American Eating in the Early Twentieth Century (Chapel Hill: The University of North Carolina Press, 2013), 84-85.
} 
standardized methods of cooking and cleaning. ${ }^{140}$ The rising fields of domestic science

and home economics sought to educate women on just how to do that. ${ }^{141}$

The content of food not only determined its purity, but also its moral value. Pure

food advocates demonized manufacturers and producers that would purposefully and

covertly adulterate their product while also condemning certain foods they considered

evil. ${ }^{142}$ Temperance advocates primarily attributed the evils of society like domestic

${ }^{140}$ Practically, more products and services that once required households to employ servants were outsourced to factories and local businesses. Therefore, the need for domestic servants decreased, and they increasingly joined the workforce outside of private homes. Culturally, middle-class women increasingly found intellectual and social value in performing and thus having complete control over household duties. As historian Helen Zoe Veit summarized the shift, the "modern housewife's combination of native intelligence, genuine familial love, and professional education made it impossible to compare her to a servant." Veit points out the ironic use of "professionalization" when referring to home economics and housework. While home economists sought to educate women on how to be "professional" housekeepers, they were effectively de-professionalizing the field of domestic labor by replacing paid servants with unpaid female family members in middle-class homes. Veit, Modern Food, Moral Food, 79-81.

Harvey Levenstein argued that the need to address the "servant problem" contributed to the overall success of the home economics revolution. Levenstein, Revolution at the Table, 60-71.

Mrs. C.S. Buell's contribution to the Lake Placid Conference on Home Economics in 1907 addressed the "servant problem." Obviously in support of modern housekeeping modeled as an organized and efficient business, Buell championed household management like that of the factory system and domestic science education for the "practical homemaker." As the president of the State Federation of Clubs in Wisconsin at the time, Buell also supported organized domestic clubs to help educate women in household management that supported the best interests of the home. Mrs. C.S. Buell, "Household Adjustment to Changing Industrial Conditions," Lake Placid Conference on Home Economics: Proceedings of the Ninth Annual Conference (1-6 July 1907), 93-99.

${ }^{141}$ Early twentieth-century professional women working in home economics strove to legitimize the relatively new field. Home economics employed principles and methodology of chemistry, medicine, agriculture, biology, and social sciences. To professionals, the term "home economics" embodied much more than general methods of good housekeeping or cooking as it employed scientific experimentation and studies. The term placed their studies within the realm of higher education as a distinct subfield of economics, which already had a recognized legitimacy. Legitimating this field was important to the women involved as it gave them hope to rank evenly with men in a scientific field. Levenstein, Revolution at the Table, 75.

Highly significant to the home economics revolution were the annual Lake Placid conferences, held from 1899 until the formation of the American Home Economics Association in 1908. Among the professionals highly involved in these conferences was Ellen Richards, a chemist and the first female graduate of the Massachusetts Institute of Technology. "Lake Placid Conference On Home Economics, 1899-1908,” The Journal of Home Economics 1, no. 1 (February 1909). Also, refer to historian Susan Strasser's Never Done for more information on the changing methods of housekeeping, the significance of domestic science and the home economics revolution, and how women reacted to these changes. Susan Strasser, Never Done: A History of American Housework (New York: Pantheon Books, 1982).

${ }^{142}$ Wilson, Swindled, 153, 163-165. 
abuse, poverty, and crime to alcohol consumption. ${ }^{143}$ They also linked alcohol and

impurities in immigrant diets. Alcohol, however, was not the only substance associated

with immorality at the turn of the twentieth century. Coffee, milk, margarine, and

mustard were some other examples of foodstuffs at times deemed impure and even

evil. ${ }^{144}$ At the National Pure Food and Drug Congress in 1898, Matthew Trimble,

Assessor of the District of Columbia, read the call for the meeting as:

The question of the character of the Food, Drink, and Drugs consumed by a people is unquestionably one of the most important that can be discussed by them. Adulteration, misbranding, sophistication, substitution and imitation undoubtably exist to an alarming extent, to the detriment of health, legitimate business, and sound morals, and it becomes needful to secure legislation that will check this growing evil and permit an honest man to do an honest business. ${ }^{145}$

143 Echoing the general sentiments of temperance advocates of the day, John Allen Krout wrote that "a nation, expanding politically, industrially and territorially, needed to take thought of the materials with which it was building. It could afford to support generously a movement against disease and poverty, against filth and misery, against drunken husbands who beat their wives and sent their children into the street to beg, against liquor dealers who grew rich while their customers filled the alms-houses and debtors' prisons.” John Allen Krout, The Origins of Prohibition, 1925, reprint (New York: Russell \& Russell, 1967), 298.

144 The purity of milk was particularly troublesome prior to pasteurization and refrigeration. Parents often fed children milk as a beverage promoting their health. In urban areas, access to milk depended on importing it daily from nearby dairy farms. Unfortunately, urban milk sellers added such things as water, chalk, and molasses to increase the daily milk supply, and thus increase their profit. Even more unfortunate, the poorer families often could not purchase this adulterated milk. They could only afford the cheap "swill milk" to feed their children. Swill milk was dangerously unhealthy and came from cows raised in cramped stalls fed spent grains from urban breweries and distilleries. At the time, the New York Times attributed upwards of 8,000 children's deaths within the city each year to swill milk. Though this may be an exaggeration, the fact remained that children who consumed the tainted milk were at greater risk of disease and death. To put it into perspective, from 1870 to 1900, nearly one third of deaths in the United States were children. Of those, between 38 and 51 percent of infant deaths were from infectious diseases, half of which could be attributed to diarrheal infections connected to consuming bad milk. Wilson, Swindled, 153162. See also E. Melanie DuPuis, Nature's Perfect Food: How Milk Became America's Drink (New York: New York University Press, 2002).

${ }^{145}$ National Pure Food and Drug Congress, Journal Proceedings of the National Pure Food and Drug Congress held in Columbian University Hall, Washington, D.C., March 2, 3, 4, and 5, 1898 (Washington, D.C., National Pure Food and Drug Congress, 1898), 4.

Sociologist Jeffrey Haydu discusses the different ways in which advocates framed the issues and tactics during the Pure Food Movement from 1879 to 1906. He cites examples from different women-led consumer groups, temperance reformers, and other pure food advocates. He concluded that framing the movement differently served the movement by forging coalitions and employing diverse tactics, 
Such extreme language coincided with other social reform rhetoric at the time, helped to build stigma around foods, and, in the hopes of critics, might harm sales.

Beer did not escape the scrutiny of pure food advocates. As early as 1879, reports of adulterants in beer included tobacco, burnt sugar or licorice, aloes, coriander seeds, cayenne pepper, salt, and soda. ${ }^{146}$ Particularly frightening was the case of arsenic poisoning in northern England beginning in the autumn of 1900 and lasting about six months. More than 6,000 people, mostly in Manchester, suffered arsenic poisoning and seventy people died. The poisoning came from contaminated invert sugar manufactured from vegetable starch and primarily used in cheap beer. This event caused wide-spread panic in Britain, and beer sales suffered greatly. Brewers responded by working closely with health authorities to remove any contaminated beer and implement safeguards to prevent future contamination. ${ }^{147}$

culminating in the Pure Food and Drug Act. Jeffrey Haydu, "Frame Brokerage in the Pure Food Movement, 1879-1906,” Social Movement Studies 11, no. 1 (January 2012): 97-112.

146 J.T. Pratt argued in 1880 that, "If, indeed, beer has or is likely to become a national beverage with us, as is claimed by the advocates of its use, its purity and wholesomeness become questions worthy of consideration.” Pratt, Food Adulteration, 101-102. Even though authors of a medicinal handbook, both doctors and professors, acknowledged that the health benefits associated with hops could be obtained through consuming beer, they admitted that "ordinary malt liquors [were] too often fraudulently adulterated to deserve such praise." They recounted an alleged colchicine poisoning from a glass of English beer that caused several people to become violently ill. Alfred Stillé and John M. Maisch, The National Dispensatory: Containing the Natural History, Chemistry, Pharmacy, Actions and Uses of Medicines, Including those Recognized in the Pharmacopoeias of the United States, Great Britain, and Germany, with Numerous References to the French Codex, 2nd ed. (Philadelphia: Henry C. Lea, 1879), 442, 718, 1448. In 1885, at the twelfth annual meeting of the American Public Health Association, Professor H.B. Cornwall claimed that most health professionals still favored the moderate use of pure malt beverages such as ale and beer despite some instances of adulteration. This demonstrates that the medical profession at the time still had uses for beers and other alcoholic beverages, in specified doses, but adulteration remained a recognized concern. H.B. Cornwall, “Adulteration of Beer," in Public Health Papers and Reports, by American Public Health Association (Concord, NH: Republican Press Association, 1885), 10:106.

${ }^{147}$ For six months, the sugar manufacturer contaminated the sugar with impure industrial-grade acid and supplied breweries with the resulting product. Brewers supported advertising and public announcements reassuring the public that beer was safe to drink. Sales returned to normal within a couple months. Matthew Copping, "Arsenic-in-Beer Scare," in Alcohol and Temperance in Modern History: An International 
In the December 1906 issue of the Western Brewer journal, USBA secretary, Gallus Thomann, addressed concerns brewers might have with the new food purity law, based on conversations USBA representatives had with Wiley himself. That address offered Wiley’s definition of beer and the approval or disapproval of certain practices and materials. As defined by Wiley in compliance with Pure Food Act, beer was "a beverage made by the alcoholic fermentation, in potable water, of barley, malt and hops, with or without unmalted cereals.” At least as it pertained to brewers, he mainly concerned himself with the use of preservatives, that only pure sugar could be used and had to be listed on any product label, and that the labels could not list any false statement. Thomann, in accordance with other publications and announcements by the USBA, recommended that all brewers comply with the Pure Food Act and the Department of Agriculture. ${ }^{148}$

In fact, beer advocates generally favored pure food regulation. For instance, several brewers voiced concerns over what materials might be considered adulterants at the hearings before the House of Representatives in 1902 on pure food legislation being proposed even then. ${ }^{149}$ In addition, many brewers attended the Pure Food Congress in St.

\footnotetext{
Encyclopedia, eds. Jack S. Blocker, Jr., David M. Fahey, and Ian R. Tyrell (Santa Barbara, CA: ABCCLIO, Inc., 2003), 1:56-57.

${ }^{148}$ Gallus Thomann, “Official: United States Brewers’ Association,” The Western Brewer: and Journal of the Barley, Malt and Hop Trades 31, no. 12 (December 15, 1906), 634-636.

${ }^{149}$ Brewers from across the country spoke on their own practices and voiced their opinions on substances such as corn, rice, and glucose used in the production of some beers. The opinions varied, but more brewers than not considered American tastes as a deciding factor in production materials and methods. For most, they noted the more competitive beers to be lighter in color and taste. For these beers, other grains such as rice or corn combined well with malted barley. Even so, several brewers remarked that they at least offered a more traditional barley, hops, water, and yeast-derived beer alongside any beers containing alternative or additional ingredients. United States House Committee on Interstate and Foreign Commerce, Hearings before the Committee on Interstate and Foreign Commerce of the House of Representatives on the PureFood Bills H.R. 3109, 12348, 9352, 276, and 4342 for Preventing the Adulteration, Misbranding, and
} 
Louis in $1905 .{ }^{150}$ In 1906, Robert Crain voiced his support and the support of the brewers he represented for a federal pure food law. ${ }^{151}$ As quoted in the March 1906 issue of The Western Brewer, Crain said, “The brewers are endeavoring now and will continue to do so to aid in every way to pass a pure food law. We are anxious to have a standard of manufacturing set by the government and a government stamp on every keg of beer showing it to be pure malt liquor containing only 3 1/2 per cent alcohol.” ${ }^{152}$ Furthermore, the pure food bill being discussed in Congress was a common topic at the 46th Annual Convention of the USBA in Indianapolis. The Western Brewer also devoted quite a bit of the June 1906 issue of The Western Brewer to the Pure Food Bill and compliance with it. ${ }^{153}$

The USBA needed to show support of the Pure Food Bill for at least two reasons: to show their dedication to manufacturing unadulterated products and to reinforce a positive relationship between American brewers and the federal government. Apparently, in the event the federal pure food bill did not go through Congress as smoothly as hoped, then the Advisory Committee of the USBA would appoint a sub-committee to draft a Standard Beer Bill. New York City brewer, Colonel Jacob Ruppert, Jr. would then present it to Congress. ${ }^{154}$ Such a committee was not necessary, USBA representatives

\footnotetext{
Imitation of Foods, Beverages, Candies, Drugs, and Condiments in the District of Columbia and the Territories, and For Regulating Interstate Traffic Therein, and For Other Purposes (Washington, D.C.: Government Printing Office, 1902), 371-381.

150 Baron, Brewed in America, 264.

${ }^{151}$ He did this during an internal revenue sub-committee meeting of the House Committee on Ways and Means held in February, even though the pure food bill was not before the committee at that time. "Against 'Blind Tigers,'” The Western Brewer, 137.

152 Ibid., 137.

153 The Western Brewer: and Journal of the Barley, Malt and Hop Trades 31, no. 6 (June 1906).

154 Jacob Ruppert, Sr. was one of New York City’s most prominent brewers. He began brewing in 1867.
} 
argued, as the Pure Food Bill gained popularity rather quickly. The Board of Trustees reported, "To carry out our resolution in the face of this state of affairs would have been unwise and highly injudicious. We would thereby have invited criticism and provoked contentions ... All we could do under the circumstances was to reiterate our unconditional approval of the pending measure; and this we have done.” ${ }^{155}$ At least six years later, brewers and their affiliates still discussed a standard beer bill. ${ }^{156}$ Compliance with federal laws like the Pure Food Act not only showed brewers' confidence in their products, but it showed their adherence to government authority similar to taxes and licensing fees.

Overall, beer industry advocates argued that beer was a viable solution to the liquor problem in America. They did not appear to be denying the presence of alcohol abuse or the connection between alcoholism and the nation's problems but instead argued that beer as a unique beverage that straddled the lines between beverage, food, and medicinal tonic, not unlike modern-day kombucha. Many brewers’ organizations still honored the conditions set by the Bavarian Purity Law passed in 1516 which limited brewers to certain pure ingredients. ${ }^{157}$ According to the USBA, the popular American

\footnotetext{
155 "Report of the Board of Trustees: Pure Food Bill," The Western Brewer: and Journal of the Barley, Malt and Hop Trades 31, no. 6 (June 1906), 300.

156 "From the Growler," American Brewers' Review 27, no. 1 (Jan. 1, 1913), 2-3.

${ }^{157}$ For bottom fermented beers, like lagers, only barley malt, hops, yeast, and water could be used. Wheat malt was allowed in top fermented beers, and pure beet-cane or invert sugar and coloring substances derived from sugar could be used in special beers. L. Narziss, “The German Beer Law,” Journal of The Institute of Brewing 90, no. 6 (Nov-Dec, 1984), 351. Interestingly, the Pure Beer Movement that lasted between 1880 and 1903 in the United Kingdom promoted legislation to restrict the types of ingredients brewers could use based on the Bavarian Purity Law of 1516. Considered by historian Matthew Copping as a campaign to revitalize the British barley industry, the Pure Beer Movement was ultimately unsuccessful
} 
beers by the turn of the twentieth century were light, low in alcohol content by volume, and contained pure, healthful ingredients. ${ }^{158}$

The rise of brewing schools, scientific research stations, and professional organizations and publications also characterized this period of brewing history. Brewers of this period, especially the larger brewers, increasingly hired scientists and innovators to help them produce more beer with greater efficiency and consistency. Brewers connected with every level of research and production, and the result was increased knowledge exchange, production, and competition among breweries. ${ }^{159}$ Key to the modern brewing schools was the incorporation of several sciences into their curriculum. For example, the Zymotechnic Institute in Chicago, directed by John Siebel, advertised courses such as a special bottlers' course lasting two months and offering instruction in

in getting any legislation passed. Copping argued that the final major attempt to pass a bill in 1901 failed, at least in part, due to the contributions of the beer industry to the United Kingdom tax revenue. Matthew Copping, "Pure Beer Movement (United Kingdom)," in Alcohol and Temperance in Modern History: An International Encyclopedia, eds. Jack S. Blocker, Jr., David M. Fahey, and Ian R. Tyrell, (Santa Barbara, CA: ABC-CLIO, Inc., 2003), 2:510. Jim Phillips and Michael French, "The Pure Beer Campaign and Arsenic Poisoning, 1896-1903,” Rural History 9, no. 2 (1998), 195-209.

${ }^{158}$ The argument went even further to contend that beer was a temperate alternative to other alcohols. A publication by the United States Brewers' Association recalling a bill exempting lager from excise laws presented by Jacob Worth to the New York State Assembly shows how supporters of the bill argued: "They asserted that owing to its small percentage of alcohol, the refreshing properties of its carbonic acid gas, the tonic properties of hops, and the nutritive quality of the extract of malt, beer is a wholesome and necessary beverage, grateful to the appetite and beneficial to the human constitution; that as a national beverage it is consistent with habits of sobriety and temperance; that in countries where its sale and consumption are protected and fostered by the government, crime as the result of intemperance is unknown; that it is the habitual beverage of that large proportion of citizens of the United States who are noted alike for their social geniality, their love of law and order, and their thrift and industry; that if protected and encouraged by wise laws, the use of beer will diminish the consumption of that class of beverages which, if indulged in to excess, are an incentive to crime." United States Brewers' Association, Documentary History of the United States Brewers’ Association (New York: United States Brewers’ Association, 1898), 2:317.

159 Peter A. Kopp, Hoptopia: A World of Agriculture and Beer in Oregon's Willamette Valley (Oakland, CA: University of California Press, 2016), 86-87. 
chemistry, physics, mathematics, mechanics, electrical and mechanical engineering, and brewing principles and techniques, as applied to bottling. ${ }^{160}$

Brewers displayed their innovations and the wealth of the beer industry at various international fairs. Their exhibitions grew more elaborate at each succeeding fair. Twenty-four brewers exhibited at the World's Columbian Exchange in Chicago in 1893, where the region's top three beer companies (Anheuser-Busch, Pabst, and Schlitz) won several medals for their beer. ${ }^{161}$ Adolphus Busch later advised, backed, and exhibited at the Louisiana Purchase Exposition in St. Louis in 1904. Among the exhibits was an Austrian-style castle and various related structures. With similar grandeur, Henry Weinhard’s brewery financed a café and beer garden while the Olympia Brewing Co. ran a Swiss chalet at the Lewis and Clark Centennial Exposition held in Portland, Oregon in 1905. ${ }^{162}$ Such grand displays helped to reinforce an image of resiliency of the beer industry in a country experiencing great economic and social changes.

To combat the resilient liquor industries, temperance advocates after 1906 continued to support local option laws and defame the saloons. The movement for a

\footnotetext{
${ }^{160}$ The Western Brewer: and Journal of the Barley, Malt and Hop Trades 31, no. 12 (Dec. 1906), 16.

${ }^{161}$ Competing breweries took the awards and medals from these fairs seriously. For example, the highest award at the Columbian Exposition in Chicago changed hands between Pabst and Anheuser-Busch several times before the fair's executive committee refused to discuss the issue further. Pabst received the award with 95 2/9 points to Anheuser-Busch’s 94 2/3 points. Many associated Pabst's Blue Ribbon beer with the Columbian Exposition, but the company began tying blue ribbons to their higher-quality, light lager named "Select" in 1882. The beer officially changed names to "Blue Ribbon" in the late 1890s. However, recognition and exposure at fairs helped to solidify the blue-ribbon image. Thomas C. Cochran, The Pabst Brewing Company: The History of an American Business (New York: New York University Press, 1948), 137-138, 177.

162 Baron, Brewed in America, 262-264.
} 
national prohibition law, however, needed reinforcement to be successful. Even though forty percent of Americans lived in dry areas by 1906, local option laws did not outlaw the private possession or consumption of alcohol. The beer and other liquor industries took advantage of interstate commerce to sell their products in dry areas. In the final decades leading to the Eighteenth Amendment, prohibitionists reorganized and became more politically active. They supported tax reform and regulation of interstate commerce. Then the world went to war, and the Prohibition Movement received the platform it needed to secure national legislation. 


\section{Chapter 3}

Beer’s Final Struggles Against National Prohibition, 1907-1920

"As devoted citizens of this country, we Americans of German birth or descent hold ourselves second to none in our devotion to the cause of true temperance and to all that makes for the sanctity and purity of the home, and decency and order in the State; but we are bitterly opposed to the passage of any law that destroys our rights of personal liberty; and for the protection of those rights we stand united as one body."

- C. J. Hexamer, President of the National German-American Alliance ${ }^{163}$

"As a question there can be no doubt that intemperance means weakness, means injury to the race, means the lowering of vitality of the individual or the nation that is the victim, and from a military standpoint it could well be urged that in this greatest crisis of the world's history this Nation and all nations abolish forever that which is a constant menace to human kind."

- Burton L. French, United States Representative from Idaho ${ }^{164}$

Heretofore, the arguments for National Prohibition contained three central themes. First, alcohol was an unnecessary evil that plagued the American public and private spheres. Second, eliminating the saloon became an essential step to freeing the American people from alcohol. Third, the way to truly eradicate alcoholism involved outlawing the manufacture and sale of all alcoholic beverages. By the end of the 1910s, well-organized and funded prohibition organizations capitalized on changing ideas of Americanization and health, the new tax structure, and the First World War to convince Americans that the nation was better off without alcohol. Numerous publications, education programs, and political campaigns helped to further their cause.

\footnotetext{
163 “The Prohibition Question: Argument Delivered by C. J. Hexamer, President of the National German American Alliance, at a Hearing before the Committee of the Judiciary of the Senate, March 9, 1912," The Penn Germania 13, no. 11-12 (Nov. - Dec., 1912), 872.

164 "The National Prohibition Amendment, Extension of Remarks of Hon. Burton L. French, of Idaho, In the House of Representatives, Monday, December 17, 1917,” Appendix and Index to Parts 1-11 of The Proceedings and Debates of the Second Session of the Sixty-Fifth Congress of the United States of America 56, part 12 (Washington, D.C.: Government Printing Office, 1918), 30.
} 
Simultaneously, beer industry advocates intensified the decades-long fight to distinguish beer from other alcoholic beverages as a healthy, economically sound, and socially acceptable beverage. They also raised further concerns about the practicality and ethics of National Prohibition. Brewers like Rudolph J. Schaefer, president of the New York State Brewers’ Association, argued that the Anti-Saloon League (ASL) employed "strong arm" methods to intimidate and coerce legislatures to favor prohibition measures. Furthermore, he and his fellow brewers struggled to secure the "property and livelihood of [their] employees against wicked and cruel confiscation." ${ }^{165}$ Brewers cited their personal liberty as Americans in defense of their businesses and those who chose to partake of their products. Regardless of brewers' efforts, the beer industry did not survive the anti-liquor campaigns. Beer received the same fate as wine and distilled liquors when National Prohibition went into effect in 1920.

For the previous half-century, the legitimacy of the beer industry mostly depended on its contributions to federal internal revenue through liquor taxes and liquor license fees. Economically, the beer industry's prosperity made it the sixth largest industry in the United States by 1914. The threat of National Prohibition meant great economic losses for not only brewers and other associated industries and business, but the federal and local revenue offices. ${ }^{166}$ Also from an economic perspective, eliminating the beer

\footnotetext{
165 “Fair Deal is Asked For,” The Western Brewer: and Journal of the Barley, Malt, and Hop Trades 52, no. 1 (Jan. 1919), 10.

${ }^{166}$ In 1914, the beer industry profited $\$ 1.5$ billion. Amy Mittelman, Brewing Battles: A History of American Beer. (New York: Algora Publishing, 2008), 80. Federal taxes on fermented liquors alone between July 1, 1913 to June 30, 1914 amounted to $\$ 66,105,444$. The tax rates changed several times prior to National Prohibition, and the rate changed again on October 22, 1914 from $\$ 1.00$ to $\$ 1.50$. By the end of the 1915 fiscal year, that is from July 1, 1914 to June 30, 1915, federal taxes on fermented liquors equaled
} 
industry would impact ancillary businesses such as the cooperage and bottling industries, saloons, hotels, and various agricultural industries, especially barley and hops.

For example, by the turn of the twentieth-century, the American hops industry had global ties with other hops and brewing industries. Hops producers exported their crops nationally and abroad, and they relied on materials sourced outside of their local regions. For instance, the Willamette Valley boosters in 1905 claimed the region's hops industry was the "Hop Center of the World.” The region promoted this title as more hops did originate in that region than any other in the nation at the time, and there was an extensive global hop trade. Willamette Valley hopyards garnered the attention of investors from various locations within and outside of the United States. Just as important to the industry were the imports of raw materials for building, cultivating, drying, storing, and distributing the hops themselves. Some examples of pest and disease prevention at the time were whale oil from Pacific Ocean whalers, bark of quassia trees from Brazil, and tobacco from the American South. ${ }^{167}$ Put into perspective, the prohibition of alcohol not only affected the alcohol producers themselves, but it had the potential of disrupting intricately connected industries and businesses, including some global ones.

In many ways, the brewers and other liquor industries did not take the Prohibition Movement as a serious threat for many years due to the security they believed the federal

\$78,460,380. “Appendix: Tables of Statistics, Internal Revenue,” United States Brewers’ Association, The 1915 Year Book of the United States Brewers' Association (New York: J.J. Little \& Ives Co., 1915), 329. The United States led the world in beer production between 1910 and 1920. The U.S. produced 1,910 million gallons, while the second and third top brewing countries, Germany and the United Kingdom, produced 1,700 and 1,490 million gallons, respectively. The European beer production greatly decreased due to political and agricultural challenges, especially the onset of the First World War. Raymond G. Anderson, "Beer," in Alcohol and Temperance in Modern History: An International Encyclopedia, eds. Jack S. Blocker, Jr., David M. Fahey, and Ian R. Tyrell (Santa Barbara, CA: ABC-CLIO, Inc., 2003) 1:97. ${ }^{167}$ Kopp, Hoptopia, 40-48. 
tax system provided. In response to the 1862 federal liquor tax, brewers openly supported liquor regulation and established a positive relationship with internal revenue officials. ${ }^{168}$ Contributions to the federal internal revenue system were often seen as patriotic sacrifices made by the industry, especially since the government would raise liquor tax rates during economic downturns to raise revenue. For example, the federal beer tax doubled from $\$ 1$ to $\$ 2$ a barrel to help cover the expenses of the Spanish-American War in $1898 .{ }^{169}$ Between 1891 and 1916, the liquor industry contributed no less than 30 percent of the federal taxes collected. ${ }^{170}$ According to the United States Brewers’ Association (USBA), the beer industry contributed approximately \$64 million in 1911 alone to the United States Treasury. This number increased to $\$ 126$ million in $1918 .{ }^{171}$

Prohibitionists were keenly aware of the significance of taxes to liquor industries, and consequently they supported legislation to dilute the liquor tax’s importance. Significant to this effect, Congress submitted the Sixteenth Amendment establishing federal income tax to the states for ratification in 1909. It went into effect in early 1913. After at least two attempts to establish a federal income tax, the Sixteenth Amendment finally presented sufficient language to grant Congress the power to collect income taxes.

\footnotetext{
${ }^{168}$ Hugh F. Fox, "The Saloon Problem,” The Annals of the American Academy of Political and Social Science 32 (Nov., 1908): 531.

${ }^{169}$ At least one source claimed that brewers contributed nearly forty percent of the entire war tax from July 1 to November 30, 1898. Another feature of the federal beer tax during times of economic stress was the reluctance to lower it. The war tax was not fully lifted until 1902. Raised taxes did affect beer sales in 1899, but sales rose again shortly afterwards. Stanley Baron, Brewed in America: A History of Beer and Ale in the United States (Boston: Little, Brown, and Company, 1962), 292-294.

${ }^{170}$ Richard F. Hamm, Shaping the Eighteenth Amendment: Temperance Reform, Legal Culture, and the Polity, 1880-1920 (Chapel Hill, NC: The University of North Carolina Press, 1995), 95-96.

${ }^{171}$ United States Brewers' Association, The Year Book with Proceedings of the Fifty-Third Annual Convention (New York: The United States Brewers' Association, 1914), 287. United States Brewers' Association, The 1918 Year Book of the United States Brewers' Association (New York: The United States Brewers’ Association, 1919), 116.
} 
The Bureau of Internal Revenue had a new stream of profits coming from working Americans, which ultimately decreased the impact of the liquor tax. ${ }^{172}$

The Webb-Kenyon Act also passed in 1913 and put further restraints on the beer industry's distribution methods. The Act gave states the right to prohibit the importation of alcoholic beverages. Breweries profited from exporting their beer to dry areas, increasing their home-delivery efforts in response to local option laws across the nation. Breweries like the Pabst Brewing Company that experienced a considerable drop in bottled-beer sales in the 1910s, largely due to local option and interstate commerce restrictions. ${ }^{173}$ The Reed-Randall Act further restricted beer distribution in 1917 by making it illegal to transport beer by mail into dry areas. ${ }^{174}$

Predictably, the brewers had business concerns that conflicted with the religious, moralistic, and material interests of the prohibitionists. ${ }^{175}$ Citing defense of personal liberty, brewers argued prohibition deprived them of basic American rights to operate legitimate businesses. ${ }^{176}$ Furthermore, while the beer industry was considered a

\footnotetext{
${ }^{172}$ Raymond W. Smock, ed., Landmark Documents on the U.S. Congress (Washington, D.C.: Congressional Quarterly, Inc., 1999), 284. Mittelman, Brewing Battles, 77-79.

173 Trading profits for bottled Pabst beer nationwide were \$597,799 in 1906 and \$133,029 in 1915. Profits dropped even more so during the United States' involvement in the First World War. Pabst's trading profits for 1917 were at their lowest before National Prohibition at \$82,908. Thomas C. Cochran The Pabst Brewing Company: The History of an American Business (New York: New York University Press, 1948), 186-187.

${ }^{174}$ William G. Ross, World War I and the American Constitution (New York: Cambridge University Press, 2017), 187-188.

${ }^{175}$ Hermann Schlüter, The Brewing Industry and the Brewery Workers' Movement in America (Cincinnati, OH: International Union of United Brewery Workmen of America, 1910), 301, 303.

${ }^{176}$ An advocate on behalf of the liquor interests, especially brewers, Percy Andreae often spoke on the threat to personal liberty that anti-liquor laws espoused. Percy Andreae, The Prohibition Movement: In Its Broader Bearings Upon Our Social, Commercial, and Religious Liberties (Chicago: Felix Mendelsohn, 1915).
} 
legitimate, capitalist industry, it could be allowed to support local and national economies.

Conversely, prohibitionists looked beyond taxation to emphasize the added economic benefits of efficiency and productivity in alcohol-free workplaces. Once delegitimized, prohibitionists argued that all industries would benefit from sober and, thus, more efficient and productive workers. Industrial work, as the editor and manager of several Anti-Saloon League (ASL) publications, Ernest Hurst Cherrington, wrote, required “not merely muscle power, but steady nerves, clear vision, alert minds, and sound judgment that can be called quickly into action.” He argued that workers simply could not perform at the necessary level of efficiency and safety if they consumed alcoholic beverages, even moderately or outside of a workday. ${ }^{177}$ Business leaders often advocated temperance to keep their workers from coming to work inebriated or missing work entirely due to alcohol consumption. ${ }^{178}$ Pubic water fountains increased in popularity during this time for similar reasons. ${ }^{179}$

\footnotetext{
177 Ernest Hurst Cherrington, ed., Standard Encyclopedia of the Alcohol Problem (Westerville, OH: American Issue Publishing Company, 1925), 1:xiv.

${ }^{178}$ Business leaders including Henry Ford and Thomas Edison, for instance, supported alcohol prohibition. Ian Tyrrell, Reforming the World: The Creation of America's Moral Empire (Princeton: Princeton University Press, 2010), 193. Multiple issues of The Dearborn Independent, published weekly by Ford supported National Prohibition. Both Edison and Ford were cited in a New York Times article as favoring Prohibition years after its implementation. "Ford and Edison Sign Dry Law Plea," New York Times, June 3, 1929.

${ }^{179}$ In Portland, Oregon, Simon Benson, successful in the lumber business, invested in bronze drinking fountains in the business districts of the city as alternative watering holes to the local saloons. Though there were many claims that Benson did this because he was a temperance man, he made it clear that money was a factor. Benson told the Oregonian, "I found that on Monday, when the men had passed Saturday night and Sunday at Clatskanine drinking and gambling, the output of my camp would fall off 25 or 30 per cent. The value of our daily output was about $\$ 10,000$, so this meant a money loss to me of $\$ 2500$ to $\$ 3000$ once a week, nearly every week in the year. Now, right there was where my opposition to whisky began.”

Interestingly, Benson claimed that he "found that when the men had been drunk on beer that their work the next day did not suffer nearly so much as when they had been drunk on whisky. I also found that men who drank beer did not want to fight as did the men who drank whisky. The beer drinkers would laugh and sing, but the whisky drinkers would fight.” "BEER HELD LESS HARMFUL: Brewed Beverage Moves Men to
} 
By the 1910s, the ASL headed a highly organized and far-reaching campaign to remove saloons. The ASL saw no hope in reforming saloons, and therefore called for their elimination on behalf of the greater good of the American society. ${ }^{180}$ At their Fifteenth Annual National Convention in 1913, they pledged to push through a federal constitutional amendment prohibiting the manufacture and sale of alcoholic beverages. ${ }^{181}$

Operating as a well-organized business, the ASL utilized political pressure and abundant propaganda to build a formidable following. ${ }^{182}$ The organization remained a non-partisan group that supported multiple parties’ candidates, but only if they favored the ASL's agenda. ${ }^{183}$ Dr. A. J. Kynett, a founder of the organization, went so far as to give military designations to the ASL: "a company in every church; a regiment in every city; an army corps in every state; a conquering army in the nation.” ${ }^{184}$ ASL officials were permanent and well-compensated, the League maintained a large dues-paying membership, published on an immense scale, and was highly politically active.

Jollity, While Distilled Liquor Inspires Fighting and Unfits Men, Theory Contended,” Oregonian, November 11, 1913.

Some cities, such as Chicago and Boston, provided a few public drinking fountains at the request of temperance advocates. However, temperance organizations and private investors continually usually resorted to funding them. Perry R. Duis, The Saloon: Public Drinking in Chicago and Boston, 1880-1920 (1983; repr., Urbana, IL: Illini Books, 1999), 190.

${ }^{180}$ Louis M. Hacker, “The Rise and Fall of Prohibition,” Current History 36, no. 6 (Sept. 1, 1932): 664.

${ }^{181}$ Anti-Saloon League of America, “The Saloon Must Go:” Proceedings Fifteenth National Convention of the Anti-Saloon League of America Twenty Year Jubilee Convention (Westerville, OH: The American Issue Publishing Company, 1913), 35-37.

${ }^{182}$ According to Peter Odegard, a pressure group such as the Anti-Saloon League was a minor group within matrices of major parties that "without regard for party opinion on other matters, [carried] on agitation for or against projects deemed favorable or prejudicial to their interests.” Peter H. Odegard, Pressure Politics: The Story of the Anti-Saloon League (New York: Columbia University Press, 1928), vii.

183 Odegard, Pressure Politics, 87-89.

${ }^{184}$ Quoted from Proceedings of the Sixteenth Anti-Saloon League Convention (Westerville, OH: American Issue Publishing Company, 1915), 110 in Odegard, Pressure Politics, 15. Odegard also provided a diagram featuring the hierarchal structure of the ASL on page 8. 
Allegedly, the ASL went so far as to unscrupulously back some public officials and forcefully drive out others, purely based on their stance on prohibition. ${ }^{185}$ Their messages were moralistic and patriotic, calling on men and women to stand in defense of family, country, and even God against the saloons and alcohol. ${ }^{186}$

Some prohibitionists offered substitutions for saloons, including a creative proposal for repurposing buildings that once housed saloons and replacing them with alcohol-free recreational places. Sodas, coffee, and teas would be substituted for beer and other liquors. Post-saloon establishments would maintain the legal activities once associated with saloons, including billiards and other games and sports. Some establishments would also provide musical performances, plays, and the increasingly popular motion pictures. ${ }^{187}$ The Salvation Army proposed temperance saloons across the nation which would keep the brass rails and other attractions of the old saloons but offer only nonalcoholic beverages. By eliminating the "social vice in its vilest form," that is the corrupted saloon, the Salvation Army's temperance saloons would provide patrons with opportunities for recreation, fellowship, and relaxation. ${ }^{188}$ In this way, even anti-saloon sympathizers recognized the social significance of the establishments.

\footnotetext{
185 Hacker, “The Rise and Fall of Prohibition,” 663-664.

186 Odegard, Pressure Politics, 40.

187 Concerns of who would own and operate these "temperance saloons" remained largely unanswered. Suggestions ranged from them being social clubs where the members would pay dues and contribute volunteer time and resources for operating and maintaining the establishment to being owned and operated by non-profit organizations. Between 1893 and 1903, a group of fifty individuals from varying occupations and disciplines conducted a series of investigations into the liquor problem facing America. They were called the "Committee of Fifty for the Investigation of the Liquor Problem.” They investigated the physiological, legislative, economic, and ethical aspects of the liquor question. They printed their results in five volumes. One volume in particular studied the saloon problem and also offered substitutions for the saloon. Raymond Calkins, Substitutes for the Saloon: An Investigation Originally Made for the Committee of Fifty, 2nd ed. (New York: Houghton Mifflin Company, 1919).

188 Calkins, Substitutes for the Saloon, x-xi.
} 
Even though breweries promoted home deliveries, having public places to sell their product was a crucial aspect of the business. ${ }^{189}$ Anti-saloon rhetoric harmed the beer industry arguably more so than the other liquor industries, due to brewers' involvement in the tied-house system. Some saloons carried illicit reputations for good reason, but the saloon culture in the United States was not entirely nefarious. Regardless of the ratio of illegal to legal activities in the saloon business, affiliation with saloons was a major factor in the beer industry's undoing and the eventual victory of the prohibitionists. ${ }^{190}$

Brewers recognized problem saloons and offered their own solutions that protected the overall saloon business. Hugh Fox, secretary to the United States Brewers' Association (USBA), argued that brewers needed to have more control over the operations of saloons so that they could directly regulate saloon activity. ${ }^{191}$ Beyond investing in saloons and saloon properties, Fox argued that brewers could go so far as to offer only beer and light wines and avoid distilled liquors, which he viewed as the real liquor problem. Moreover, he argued that over-competition between saloons contributed

\footnotetext{
${ }^{189}$ According to historian Thomas C. Cochran, Captain Frederick Pabst sought expensive retail outlets, such as hotels and restaurants, with the goal of associating his beer with respectable places. So, when a potential customer saw the Pabst sign outside certain places, they would view it as "a badge of standing and respectability.” While acknowledging the working-class' attraction to beer, Pabst hoped to associate beer with luxury by selling in certain outlets. He enhanced Pabst's image through extensive advertising campaigns. Cochran, The Pabst Brewing Company, 210-248.

${ }^{190}$ Baron, Brewed in America, 273. Madelon Powers, Faces Along the Bar: Lore and Order in the Workingman's Saloon, 1870-1920 (Chicago: The University of Chicago Press, 1998), 16, 209.

${ }^{191}$ Feeling a sense of responsibility for saloons, beer industry supporters insisted that the best solution to the saloon problem would be allowing brewers to regulate saloons themselves, and thus eliminating misconduct. More legal authority given to brewers would allow them to purge the saloon business and leave the law-abiding ones to provide their services. Fox argued that service in saloons was efficient, fast, and clean in comparison with "soda fountains" and "quick-lunch counters." By pushing back against emotional and moralistic anti-saloon arguments with their logical, business-minded, and practical concerns, Fox and others meant to show how unreasonable prohibition was in comparison with good business. Andreae, The Prohibition Movement, 72-85. Fox, “The Saloon Problem,” 533-538.
} 
to lawless activity. If an area could only accommodate one saloon and had three, then the saloons might be inclined to resort to illegal activities to increase profits. Fox offered a solution to this problem by having local governments assess an area and determine the appropriate number of saloons that the area could accommodate. This sort of analysis would allow local authorities to prevent lawlessness and maintain the benefits of having reputable saloons. ${ }^{192}$

Beer industry advocates further argued that prohibition laws would not eliminate the liquor problem by eliminating saloons. They pointed to the failures of existing prohibition laws, such as Sunday-closing and local option laws. Instead, the USBA Board of Trustees 1908 report presented three suggestions for solving the liquor problem: create a better system for regulating the sale of alcohol and the places where it was sold, encourage the sale of low-alcohol beverages, and educate the public on self-control and moderation. ${ }^{193}$ Providing solutions, not just defenses, showed the beer industry’s more proactive nature in the twentieth century.

Economic interests and the saloon culture were largely contained in the public sphere, but a major feature of social reform continued to be the defense of the private sphere: the American home. For example, several ASL pamphlets claimed the saloon as an enemy to children and the home. In effect, the ASL placed Saloon Defenders against

\footnotetext{
192 Fox, “The Saloon Problem,” 536-538.

${ }^{193}$ In the same report, the trustees argued that "the average saloon is conducted in as decent and businesslike a fashion as a grocery store.” Brewing advocates insisted that the percentage of lawless saloons was between 5 and 10 percent of the total number of saloons. Fox, “The Saloon Problem,” 532-533, 538. Andreae, The Prohibition Movement, 84.
} 
Home Defenders, charging them with corrupting children and enabling domestic abuse. ${ }^{194}$ For decades, the beer industry promoted their product as a "temperance beverage," but the increasing threat of National Prohibition led brewers to be more aggressive in their image control. To remain relevant, and thus legal, the beer industry increased efforts to establish itself as a "home beverage.”

Essentially "temperance” and "home” beverages were the same thing, but beer as a home beverage made it relatable to those who might approve of the beverage but not drinking in public. Breweries especially advertised their low-alcohol lagers for home consumption. They promoted a healthy and wholesome beverage that was not only safe in the home but a much better alternative to spirits. ${ }^{195}$ In a series of installments in the Western Brewer trade journal in 1913 called “A Talk on the Advertising of Beer,” the author argued that beer was not another drink to lump in with "whiskey, gin and other strong alcoholic drinks.” Instead, it was a "home beverage” that had "exceptional tonic and food properties.”196

\footnotetext{
194 Odegard, Pressure Politics, 40-42.

${ }^{195}$ A couple examples of beer advertising during the early twentieth century came from Pabst Brewing Company of Milwaukee, Wisconsin. A 1907 advertisement read that Pabst beer was made from nourishing eight-day malt, the choicest hops, and purely clean water that made it both "refreshing and satisfying." To cement its quality and status as an "ideal temperance beverage," Pabst beer only contained 3.5\% alcohol. The brewery advertised in 1911 their beer as the "ideal family beverage" that even uninvited guests would "like and appreciate." Pabst boasted low alcohol percentage, gentle stimulation of digestion, and "high food value" that "[placed] it among the most valuable of pure foods." Not to mention, it had an agreeable flavor. Citing a prominent women's suffrage activist, Phoebe Cousins, the advertisement simultaneously appealed to American women and patriotism. Cousins allegedly reported that beer was a successful and welcome alternative to all other alcoholic beverages at army canteens where only beer was permitted. Supposedly, the success of the beer-only canteens put the surrounding illicit dives out of business. If it was good enough for American soldiers, the advertisement prompted, then why not adopt beer as a healthy alternative to other alcohols nationwide? There would be no need for national prohibition, just substitution. Pabst Beer, "Judge Beer By Its True Worth," advertisement, The Biloxi Daily Herald, January 1, 1907. Pabst Blue Ribbon, "When Company Comes," advertisement, The Morning Oregonian, January 19, 1911.

${ }^{196}$ The unnamed author promoted home delivery, what he called the "home trade," over selling beer in a saloon. He argued that it was more profitable and a "cleaner, more desirable business." As part of his series, he suggested breweries increase their home delivery advertising campaigns. "A Talk on the
} 
Rather than deny a relationship between excessive drinking and poverty, those in the beer industry reversed the narrative and focused on how beer was a solution for those social problems. Hugh Fox argued that alcoholism was not the only social issue associated with extreme poverty. Sanitation issues, malnourishment, disease, and reduced vitality were some additional issues. ${ }^{197}$ Beer, however, derived from pure ingredients in modern, clean breweries; it provided nourishment; it promoted good digestion and hops provided natural anti-bacterial benefits; and it promoted vitality. Moreover, the beer industry benefited families through employment of thousands of Americans nationwide. So long as it was consumed responsibly, the argument went, beer was "liquid bread" that “constituted a necessity of life.” 198

A continued point of contention for prohibitionists was the influence of immigrant diets on their assimilation into American society. ${ }^{199}$ Waves of immigration from Ireland, Italy, and Eastern European countries at the turn of the twentieth century concentrated in urban areas. Many social workers, public health workers, and dietary reformers feared that immigrant populations prepared and consumed food in unhealthy and uneconomical

Advertising of Beer," The Western Brewer: and Journal of the Barley, Malt, and Hop Trades 40, no. 6 (June, 1913), 245-246.

${ }^{197}$ Fox, “The Saloon Problem,” 532.

198 One Hundred Years of Brewing: A Complete History of the progress made in the Art, Science and Industry of Brewing in the world, particularly during the last Century (Chicago: H.S. Rich \& Co., 1901), 226.

${ }^{199}$ By the 1910s, several Americans were concerned with social hygiene, prompting laws regulating marriage, conception, and interaction between races. For example, a eugenics law passed in 1913 in Minnesota required a certificate from a physician for a prospective groom prior to issuing a marriage license. A further law required that railroad companies supply every passenger traveling at least ten consecutive miles with their own drinking cups. The old tradition of a public drinking cup was no longer allowed. "Three New Laws Now in Effect: Eugenics Law and State Forcing Railroads to Furnish Drinking Cups Main Ones,” The Duluth News Tribune, January 2, 1914. 
ways. They argued that malnourishment among immigrants was due to ignorance, not poverty. Since many reformers also advocated for domestic science and home economics, they promoted Americanizing immigrant diets and behaviors. Supposedly, good Americans did not consume overly complicated foods. They did not overly consume at all. Overeating, mixing foods, and using strong seasonings overworked the digestive system and often led to indigestion, which then lead to consuming alcohol as a remedy. ${ }^{200}$

Even though immigrant populations tended to maintain at least some food traditions from their countries of origin, they necessarily adapted to the food markets where they settled in the United States. The makeup of immigrant diets came more from circumstances of the day than social reform. The "boom-and-bust economy" at the turn of the twentieth century dramatically influenced working-class incomes, which many immigrants depended on. Health insurance, sick pay, social security, and other means of protecting those that could not work for any number of reasons did not come about until decades later. If one could not work, then one had to depend on other family members or the kindness of the community. Income fluctuations could mean meat for dinner one week and none the next. Essentially, the working classes relied on available and affordable food. Working-class diets changed as improved transportation brought more

\footnotetext{
${ }^{200}$ Harvey Levenstein, Revolution at the Table: Transformation of the American Diet (Berkeley, CA: University of California Press, 2003), 103-104.

Cooking schools employed domestic science in their curriculum. One cookbook first published in 1896 was so popular that it was revised several times and reprints continue to be published today. Fannie Merritt Farmer attended the Boston Cooking-School in the 1880s, eventually became its principal, and wrote The Boston-Cooking School Cook Book. The book appears more like a text-book with scientific explanations for food choices and cooking methods, standardized measurements, preservation techniques, food values, and more. In it, very few spices outside of salt and pepper are recommended for use. Farmer opened her own cooking school in 1902 and also lectured at the Harvard Medical School on nutrition for sick persons. Fannie Merritt Farmer, The Boston Cooking-School Cook Book, rev. ed. (Boston: Little, Brown, and Company, 1929).
} 
food into their neighborhoods and methods of food preservation became more affordable. $^{201}$

Immigration and immigrant culture was undeniably significant to the American beer industry. Even though beer was a universal beverage consumed by members of every class in American society, it was especially prominent among the working class. Since so many immigrants belonged to the working class, the beer industry relied heavily on their patronage. Furthermore, since their beginnings in the mid-nineteenth century, most of the national brand brewers in the United States were German immigrants or close descendants. The popular American lagers evolved from German lagers. Breweries often depicted traditional German landscapes and social settings to sell their German-style beers. Beer and breweries also carried German-inspired names. Therefore, any reform of immigrant diets had an impact on the beer industry. By promoting their product as a healthful beverage conducive to the American diet, brewers presented beer as a better alternative to other alcoholic beverages. ${ }^{202}$ However, when the First World War broke out in Europe, prohibitionists utilized American fears of Germany and all things German in their fight against beer and saloons.

\footnotetext{
${ }^{201}$ Ibid., 98-108. Historian Susan Strasser agreed that transportation and food-preservation techniques increased food variety even in diets of the poor. Susan Strasser, Never Done: A History of American Housework (New York: Pantheon Books, 1982), 12.

${ }^{202}$ Historian Harvey Levenstein presented trends in food consumption habits at the turn of the twentieth century in his work, Revolution at the Table. In general, Americans consumed more salt, meats, and starches during this period. Such foods paired well with the light, crisp, lagers popular at the time. Harvey Levenstein, Revolution at the Table: Transformation of the American Diet (Berkeley, CA: University of California Press, 2003).
} 
Following the onset of the First World War in 1914, the Anti-Saloon League (ASL) and other prohibitionists capitalized on wartime conditions to persuade the nation against alcoholic beverages. Anti-German sentiment increased significantly once America officially entered the war in April 1917. Even though prohibitionists continued to reference the "liquor industry" or "liquor interests" when arguing against alcohol, many publications pointed specifically to brewers and beer industry affiliates. The language in prohibition publications changed to be more anti-German, and thus anti-beer. They deemed the production of alcohol a waste of materials and manpower that would be better employed in the war effort. Economically, the ASL blamed the beer industry for using millions of bushels of grain each month, taking valuable space on railway cars, employing too many able-bodied men, and dedicating billions of dollars to an unnecessary and unhealthy beverage. The German heritage of most brewers supposedly added to the unpatriotic nature of the whole liquor industry. ${ }^{203}$

Using patriotic rhetoric, the ASL aimed to convince the American public and lawmakers that materials used by the liquor industries, especially barley, wheat, rice, and

\footnotetext{
${ }^{203}$ Odegard, Pressure Politics, 67-69. Hacker, "The Rise and Fall of Prohibition,” 664-665. Following America's declaration of war and entrance into World War I, the Anti-Saloon League drastically increased its anti-German rhetoric and distrust of German-American brewers. During the proceedings of the 1917 convention, Rev. A.C. Bane followed the welcoming address with sentiment that was echoed throughout the convention: "The brewers own or control most of America's disgraceful saloons, and maintain the greatest and most dangerous trust in the nation. The breweries of this country are German owned and operated; are hot-beds of pro-German sentiment akin to treason; are utterly un-American to the core, and wield the most corrupt political influence in the Republic. Why does the government spare beer to weaken our army and to fill German coffers with money, with which to fight America and democracy? Let us spare our fighting boys rather than our foaming beer." Rev. A.C. Bane, "Response to the Address of Welcome," Proceedings: Eighteenth National Convention of the Anti-Saloon League of America (Westerville, OH: The American Issue Publishing Company, 1917), 23.
} 
corn should be redirected to the war effort. ${ }^{204}$ They embraced the popular slogan from the United States Food Administration’s conservation campaign, “Food will win the war.” The connection between morality and food consumption championed during the Pure Food Movement grew to include patriotism during the war. ${ }^{205}$ In 1917 , Congress debated on the Food and Fuel Control Act, or Lever Act, named after the Chairman of the House Committee on Agriculture and Democratic Representative from South Carolina, Asbury F. Lever. The act regulated the production, distribution, and pricing of food and fuel as a war measure. ${ }^{206}$ In the discussion on food conservation, prohibitionists argued that the production of alcoholic beverages should be prohibited. A heated debate over whether to prohibit the production of all alcoholic beverages, including beer and wine, lasted until the act passed on August 10. Ultimately, enough senators threatened to filibuster the entire act if it was not amended to exclude beer and wine that a compromise was reached to prohibit the production of distilled liquors, while giving the president the authority to extend the restriction to beer and wine if necessary. ${ }^{207}$

\footnotetext{
204 The estimated figures for profit, labor, and number of foodstuffs used by the beer industry fluctuate greatly depending on the source. The beer industry often argued that only one percent of the total amount of grain cultivated in the U.S. was used in the production of beer annually.

To turn this figure on its head, Charles Stelzle used mathematical deduction to emphasize the seriousness of the liquor problem. He argued that one percent of the grain would feed one percent of the people. Since there were approximately 100,000,000 people in the United States, one percent of the grain would feed $1,000,000$ people. Figuring that the U.S. would send about 1,000,000 soldiers to France that year alone, Stelzle concluded that the "liquor men have been wasting enough grain to feed every last man who will go to the trenches!” Even more profound, Stelzle argued that the success of the war would come down to the last million bushels of grain. Charles Stelzle, Why Prohibition! (New York: George H. Doran Company, 1918), 26-27.

${ }^{205}$ Helen Zoe Veit, Modern Food, Moral Food: Self-Control, Science, and the Rise of Modern American Eating in the Early Twentieth Century (Chapel Hill: The University of North Carolina Press, 2013). Stelzle, Why Prohibition!

${ }^{206}$ Historian William G. Ross researched the relationship between the federal government and the First World War as it pertained to military, political, economic, and social changes. Ross, World War I and the American Constitution, 58.

${ }^{207}$ Odegard, Pressure Politics, 166-171.
} 
In mobilizing the homefront during the war, it was important for Americans to use self-control in food consumption at a time when the world suffered shortages. Even more so, renouncing some food pleasures showed individual self-discipline and thus moral virtue. The Food Administration used the slogan, "Victory Over Ourselves," to encourage the home front to make the necessary sacrifices for the greater good. ${ }^{208}$ Americans were encouraged to eat meals without meat and wheat to save those commodities for fueling the military. In food conservation, housewives increased their social and political significance. ${ }^{209}$ Food Administrators, home economists, and several socially and politically active women praised housewives that implemented food conservation methods in their households. The rhetoric was often dramatic, placing housewives in positions comparable to soldiers on the frontlines, fighting for worldwide democracy. ${ }^{210}$

With patriotic fervor, prohibitionists equated alcohol to America's enemies overseas. Calling up lines from speeches and correspondences from American leaders and heroes, they deemed alcohol the enemy and patriotism as staunchly anti-alcohol. Charles Stelzle, a prohibition activist, stated that Americans not only had to fight with Kaiser Bill Hohenzollern but with Kaiser John Barleycorn, further demonizing the

\footnotetext{
${ }^{208}$ Veit argued in Modern Food, Moral Food that industrialization of food production and distribution, advances in food sciences, the institutionalization of home economics in public schools, and Progressive Era reforms transformed how Americans viewed food. Especially considering World War I, the strength of American society within a global context required that individual citizens consume certain foods in particular ways. Home economists, domestic scientists, and food conservationists promoted rational food choices, production, and distribution. Addressing food concerns coincided with addressing social concerns. In a similar vein, contemporary author John Allen Krout wrote, "Stressing the principle of self-denial, abstinence not only freed men from slavish subjection to appetite, but it prepared them through the purifying influence of this asceticism for greater co-operation with their fellows.” John Allen Krout, The Origins of Prohibition, 1925, reprint (New York: Russell \& Russell, 1967), 298.

${ }^{209}$ Veit, Modern Food, Moral Food, 79-80.

${ }^{210}$ Ibid., 91-93.
} 
character from folklore. ${ }^{211}$ In his plea, he asked fellow Americans, "Have we the courage to destroy the enemy within our gates, who is stealing away our brains, weakening our brawn, and making flabby the morale of our nation at a time when all forward-looking men should be fighting to 'make the world safe for democracy'?” He argued that "there never was a time when America so needed her sober senses as to-day - it is a time when selfishness must be subordinated to the great task of winning the war." ${ }^{212}$ Such rhetoric, full of emotional conviction, found footholds in prohibition-backed publications nationwide.

The Anti-Saloon League (ASL) escalated the argument against alcohol to accusations of treason. Like Stelzle, the ASL condemned all German brewers and allied liquor industries to abolishment for being anti-American and pro-German. They specifically blamed German brewers for assisting the Central Powers and undermining the American war effort. First, they claimed that beer caused a significant portion of Americans to be too drunk to work or fight. Second, they accused German brewers and the German-American Alliance for encouraging German immigrants not to fully assimilate into American society and culture. Third, they alleged corruption and nefarious dealings associated with the beer industry, such as buying or threatening politicians and of restricting the federal government in controlling the liquor interests. ${ }^{213}$ The ASL's arguments increasingly got the attention of many Americans.

\footnotetext{
${ }^{211}$ It is ironic that John Barleycorn derived from Scottish and English folksongs, not German. For more information on John Barleycorn, reference Peter Wood, "John Barleycorn: The Evolution of a Folk-song Family,” Folk Music Journal 8, no. 4 (2004), http://www.jstor.org/stable/4522718 (accessed September 24, 2017).

${ }^{212}$ Stelzle, Why Prohibition!, 22-23, 34-42.

${ }^{213}$ Odegard, Pressure Politics, 70-72.
} 
In September 1918, as the war was ending, a U.S. Senate Subcommittee on the Judiciary embodied some of the typical anti-German rhetoric in their series of hearings investigating the United States Brewers’ Association (USBA) and their allied interests. ${ }^{214}$ The subcommittee met considering a resolution presented to the Senate by A. Mitchell Palmer, Custodian of Alien Property and former Democratic Representative from Pennsylvania. Palmer accused up to fifteen German brewers in association with the USBA of discretely financing large newspapers that in turn supported the interests of the "liquor traffic," which he found to be “vicious” and "unpatriotic, because it has been proGerman in its sympathies and its conduct.” Furthermore, Palmer claimed that "around these great brewery organizations owned by rich men, almost all of them are of German birth and sympathy.” He further criticized German brewers for supporting “all the organizations of this country intended to keep young German immigrants from becoming real American citizens.” Palmer’s resolution maintained that brewing companies in association with the USBA bought elections and political officials, purchased significant advertising and editorial space for their propaganda, supported boycotting American goods and interests, and much more up to and including tax fraud. ${ }^{215}$

With such animosity towards the liquor industries generally, and the beer industry specificallys, brewers had to provide significant defense to safeguard their industry

\footnotetext{
${ }^{214}$ United States Senate Committee on the Judiciary, Brewing and Liquor Interests and German Propaganda: Hearings Before a Subcommittee on the Committee on the Judiciary, United States Senate, Sixty-Fifth Congress, Second Session, Pursuant to S. RES. 307, A Resolution Authorizing and Directing the Committee on the Judiciary to Call for Certain Evidence and Documents Relating to Charges Made Against the United States Brewers' Association and Allied Interests and to Submit a Report of Their Investigation to the Senate (Washington, D.C.: Government Printing Office, 1919).

${ }^{215}$ Brewing and Liquor Interests and German Propaganda, 1:3-4. The newspapers of concern were the Washington [D.C.] Times and the New York Evening Mail. Maureen Ogle, Ambitious Brew: The Story of American Beer (Orlando, FL: Harcourt, Inc., 2006), 178-182.
} 
against National Prohibition. ${ }^{216}$ Brewers confronted anti-German sentiments in multiple ways, including changing their products’ names, advertising with pro-American propaganda, and investing in America’s war effort. Beyond contributing millions of dollars in taxes to the internal revenue, many brewers made private investments in war bonds. For example, Lily Busch, widow to St. Louis’ iconic brewer Adolphus Busch, reportedly purchased Liberty bonds for $\$ 100,000$ in 1917 , while the family’s total contribution to that point was $\$ 500,000 .^{217}$

Even with the success of anti-alcohol efforts, beer industry interests remained hopeful that it would survive any national prohibition law. An article in the July 1917 Western Brewer showed confidence that the federal government would not prohibit beer and light wines in the wake of the possible new amendment prohibiting alcohol.

Particularly, the beer industry hoped that the legal alcohol limit would be closer to the 2.5 to 4 percent by weight average of light lagers. This provision would ban distilled liquors, leaving the beer and lighter alcoholic beverage industries to fill the void. Finally, they

\footnotetext{
${ }^{216}$ Disagreements between the different liquor interests made it difficult for them to organize into single organizations. This most likely contributed to their unpopularity in general. However, some organizations did exist that considered multiple liquor interests. Namely, the National Wholesale Liquor Dealers Association of America published an anti-prohibition manual with distillers, brewers, and vintners in mind. National Wholesale Liquor Dealers Association of America, The Anti-Prohibition Manual: A Summary of Facts and Figures Dealing with Prohibition (Cincinnati: National Wholesale Liquor Dealers Association of America, 1916, 1918).

${ }^{217}$ Interestingly, Mrs. Busch was living in Munich at that time, conducting a hospital for wounded German soldiers. "Is in Germany But Buys Liberty Bonds," The Western Brewer: and Journal of the Barley, Malt, and Hop Trades 48, no.6 (June 1917), 226.
} 
hoped the public and government would acknowledge what brewers had been arguing for decades, that is, that beer and spirits are not the same. ${ }^{218}$

Fortunately for the beer industry, the Lever Act passed in August 1917 without any restrictions on beer production or sale. However, in December, President Woodrow Wilson used the authority given to him by the Lever Act to restrict grain to brewers and reduce the legal alcohol content of beer to 2.75 percent by weight. ${ }^{219}$ In November 1918 , after the signing of the armistice ending the war, Wilson signed an Agricultural Stimulation Bill that prohibited brewing after May 1, 1919 and the sale of beer after July 1, 1919. The bill was supposed to only last the duration of demobilization, but prohibitionists were already working to pass a permanent prohibition law. ${ }^{220}$

On August 1, 1917, the Senate passed the Eighteenth Amendment, with 65 votes in support and 20 votes against it. On December 17, the House voted in support 282 votes to 128 . On January 8, 1918, Mississippi became the first state to ratify the Amendment and, within fourteen months, the necessary 36 states ratified it. In time, 46 of the then 48 United States ratified the amendment. Even then, brewers hoped that the amendment's enforcement act would maintain that beverages containing 2.75 percent or less of alcohol by weight, the war-time alcohol limit, were not “intoxicating beverages.” However, Congress passed the Volstead Act, named after its chief sponsor, Republican Representative from Minnesota Andrew J. Volstead, placing all beverages containing

\footnotetext{
218 “No Ban on Beer," The Western Brewer: and Journal of the Barley, Malt, and Hop Trades 48, no. 7 (July 1917), 27-28.

${ }^{219}$ Ross, World War I and the American Constitution, 196.

${ }^{220}$ Cochran, The Pabst Brewing Company, 322.
} 
more than one-half of one percent of alcohol within the category of "intoxicating

beverages.”221

At once, the beer industry's decades of defense, adaptation, and offensive strategies proved insufficient to separate beer from the other liquor industries. To keep beer and light wines legal, President Woodrow Wilson vetoed the act, but Congress overrode his veto on October 28, 1919. ${ }^{222}$ On January 16, 1920, the Secretary of State proclaimed the Eighteenth Amendment in effect. Further regulation of alcohol use for industrial, sacramental, or medicinal purposes greatly restricted the entire liquor industry, including beer, and provided new obstacles to overcome. ${ }^{223}$

\footnotetext{
${ }^{221}$ Brewers' optimism at this time was backed by newspapers and their own studies arguing that beer produced during the war, comprising around 2.75 percent alcohol, was not intoxicating. Brewers called the alcohol percentage presented by Volstead arbitrary, and they filed lawsuits against the federal government. However, the courts sided with the government and beer containing more than one-half of one percent alcohol could only be lawfully produced for medicinal purposes. "Litigation by the Brewers," The 1919 Yearbook of the United States Brewers' Association (New York: United States Brewers' Association, 1920), 50-112. Baron, Brewed in America, 311-313.

${ }^{222}$ President Wilson opposed adding national prohibition to the war-time Food Bill in June of 1917. Senator Thomas Gore held a conference with the president after the bill passed the House of Representatives and was being considered by the Senate. The President agreed with Gore and other senators with similar reservations that adding the ban on alcoholic beverages to the bill at all was a mistake that would prolong its passage. Evidently, Wilson felt that the Food Bill needed to pass quickly to address the urgency of war-time needs. However, convinced that the legislation concerning liquor could not be removed once it passed the House, he approved Gore's proposed amendment banning the manufacture and sale of distilled spirits, leaving beer and wine production alone. Since some alcohol had to be banned, then the best solution was to ban the beverages containing the highest levels of alcohol. Wilson voiced concern that American workers would not be content if they could not access beer during their leisure times. Again, the argument was that the Food Bill was necessary and needed to be passed quickly. As part of the compromise, the president would have discretionary power to ban production of beer and wine if needed. According to a New York Times article on June 30, most senators and house representatives appeared confident that Senator Gore's amendment would pass the Senate vote. "President Stops the Prohibition of Beer and Wine," The New York Times, June 30, 1917.

${ }^{223}$ Hacker, “The Rise and Fall of Prohibition,” 665. Smock, Landmark Documents, 309-314.
} 
Epilogue: On the American Beer Industry after 1920

The Prohibition era between 1920 and 1933 impacted the American people in ways that those who originally supported the Eighteenth Amendment did not foresee. Not only were the liquor and affiliated industries negatively affected, but Americans almost instantly turned to illicit liquor production. Well before National Prohibition went into effect, beer industry advocates argued that total prohibition was impractical and, in many ways, harmful to the American economy and society. Industries no longer paid the taxes that had on several occasions bolstered internal revenue. As businesses closed, workers lost jobs. Crime related to the illegal liquor trades infiltrated towns and cities across the nation. The era meant to usher in the nation's salvation allowed some of its most dangerous residents to successfully gain power and influence.

In the case of the beer industry, National Prohibition disrupted its position as America's most-consumed alcoholic beverage and a top-grossing industry. During the Prohibition Era, only the largest breweries could afford to make the necessary changes to produce legal products. Most local breweries had to liquidate property and equipment, leaving the brewing business altogether. Those breweries that had the means, adapted their buildings and machinery to produce non-alcoholic products like near beer, soda, yeast products, vinegar, malt extract, and industrial alcohol. ${ }^{224}$ Many breweries did what was necessary to remain active with hopes that National Prohibition would not last.

It took some time, but the American beer industry did recover from the "dry decade” of the Prohibition Era. When the Twenty-First Amendment repealed the

${ }^{224}$ Stanley Baron, Brewed in America: A History of Beer and Ale in the United States (Boston: Little, Brown, and Company, 1962), 313. 
Eighteenth in 1933, liquor licensing and distribution laws created distance between breweries and retail outlets that remained strained until recent decades. Laws regulating the sale of alcohol worked against the beer industry in unintentional ways, such as making it difficult for independent breweries to turn a profit and thus add variety to American beer styles. Nearly one hundred years after America’s beer industry experienced its boost during the Industrial Revolution, and fifty years after the repeal of National Prohibition, a wave of small-scale brewers ushered in the craft beer movement and revolutionized the American beer culture. Following is a brief examination of three periods of the beer history after 1920 that showcase the industry's resilience in difficult times.

\section{The Prohibition Era: 1920-1933}

Even in defeat, anti-Prohibitionists attempted to overturn the Eighteenth Amendment and the one-half of one percent alcohol level restriction defined by the Volstead Act. New York City brewer, Jacob Ruppert, even brought a case against the U.S. District Attorney Francis G. Caffey and Acting Collector of Internal Revenue Richard J. McElligott arguing that Congress overstepped its power to prohibit alcoholic beverages containing more than 2.75 percent alcohol by weight, which was legally predetermined to be the level of intoxication. The U.S. Supreme Court Justice Louis Brandeis ruled on January 6, 1920 that each of Ruppert's objections were invalid, that Congress had full power to pass the Volstead Act, and that the one-half of one percent 
alcohol by volume conditions of the Volstead Act remained valid. ${ }^{225}$ More court cases arose, with one of the more organized attempts being seven cases brought before the U.S. Supreme Court in 1920, commonly known as the National Prohibition cases or by the leading case, Rhode Island $v$. Palmer. The prosecution argued against the constitutionality of the Eighteenth Amendment and the Volstead Act. Most of the objections aimed to make alcohol prohibition a state-by-state matter and not under federal jurisdiction. Ultimately, however, the court ruled that each of the objections were invalid. ${ }^{226}$

In some states, residents attempted to override ratification of the Eighteenth Amendment by implementing a popular referendum. Ohio residents took this charge farther than any other state. The Ohio legislation voted to ratify the Eighteenth Amendment on January 7, 1919, becoming one of the thirty-six states needed to amend the Constitution. According to an Ohio law adopted in 1917, a petition signed by at least six percent of the state's voters would force a referendum. Ohio residents took advantage of the earlier law to file a referendum petition on March 11, 1919 concerning the state’s ratification of the Eighteenth Amendment. The Ohio Secretary of State, Harvey C. Smith ordered a referendum at the November 1919 general election. At that election, voters overturned ratification by a narrow 479 votes.

\footnotetext{
${ }^{225}$ In response to Ruppert's objections, the court made it clear that the Volstead Act overshadowed all previous federal prohibition measures and clearly defined all alcoholic beverages containing more than one-half of one percent alcohol by volume as intoxicating. Even the language of "by weight" or "by volume" left to debate by the various prohibition measures was cleared by Ruppert $v$. Caffey. Measuring by weight allowed for higher alcoholic content by volume. Jacob Ruppert v. Caffey, 251 U.S. 264 (1920). ${ }^{226}$ Rhode Island was one of two states that rejected the Eighteenth Amendment. Connecticut also rejected the amendment but ratified it in May 1919. Rhode Island never ratified it. Rhode Island v. Palmer, 253 U.S. 350 (1920).
} 
This did not sit well with Ohio's prohibitionists, and they questioned the constitutionality of a popular referendum overriding a state legislature's ratification of a federal amendment. Cincinnati attorney and prohibitionist, George S. Hawke took the lead in the case brought before the U.S. Supreme Court against the referendum, referred to as Hawke v. Smith. The Supreme Court ultimately rejected the referendum as unconstitutional, holding that the federal Constitution empowered states’ legislative bodies to accept or decline a federal amendment. Hawke v. Smith showed how bureaucracy could overrule a popular vote. The country took note of Ohio’s experience, and anti-prohibitionists used it in their campaign to sew popular resentment towards National Prohibition. ${ }^{227}$

The anti-liquor organizations in 1920 expressed heightened enthusiasm at the success of passing National Prohibition in the United States. America hosted the Fifteenth International Congress Against Alcoholism that year in Washington, D.C., the first of such congress held after the First World War. The post-war international congresses served as arenas to exchange knowledge and debate remedies to the alcohol problem. International and transnational relationships developed at these congresses. Recurring topics included medical research of the effects of alcohol on individuals, international alcohol restrictions, the roles of women's citizenship, and racial hygiene in solving the alcohol problem. ${ }^{228}$

\footnotetext{
227 David E. Kyvig, Repealing National Prohibition, 2nd ed. (Kent, OH: The Kent State University Press, 2000), 14-16.

228 Johan Edman, “Transnational Nationalism and Idealistic Science: The Alcohol Question between the Wars,” Social History of Medicine 29, no. 3 (2016): 590-610. Proceedings from these international congresses on alcohol help to compare the American experience with that of other nations over time.
} 
Though the atmosphere at these congresses changed between the wars, the first interwar congress held in 1920 was rife with optimism and, especially, American enthusiasm for global alcohol prohibition. Congress speakers touted the military and industrial efficiency of having sober soldiers and workers. They supported social purity through anti-alcohol regulations. Women, who had recently gained citizenship and voting rights in many countries, were commended for their roles in the anti-alcohol movements. Liquor industries, with their economic and political power, were increasingly villainized at the international congresses as contributors to alcoholism, corruption, and organized crime. $^{229}$

With the policy of National Prohibition still fresh to Americans, speakers at the 1920 International Congress addressed some of the early objections to banning all alcoholic substances. Specifically, they discussed some of the issues surrounding the use of beer and light wines as alternatives to beverages with higher alcohol content. For example, De Lancy Carter, physician and President of the American Medical Society for the Study of Alcohol and Other Narcotics, addressed concerns of whether the Eighteenth Amendment was right to outlaw beer and light wines as intoxicants. Supporting the language of the Amendment, he referenced medical research that showed how any amount of alcohol was poisonous and acted as an intoxicant. Even though people might admire the relatively lower percentage of alcohol in beer and light wines, Carter placed them well within the influence of the Eighteenth Amendment and condemned them for diminishing "that moral, mental, and physical standard so necessary to the good of

${ }^{229}$ Ibid., 590-610. 
mankind.” He concluded his remarks by commending the Eighteenth Amendment for doing away with the "corner saloon ... the basis for all our bad results for the humankind." 230

A. Holitscher, physician and the General Secretary of the International Medical Total Abstinence Association, further condemned beer and wines for their contribution to the inebriety of entire nations. He called out those who considered beer separate from distilled spirits and therefore "harmless, useful, necessary.” Holitscher argued that neither drinking beer nor wine exclusively solved the alcohol question. To him, Americans were right to prohibit all alcoholic beverages, since it was the only viable solution. ${ }^{231}$

Regardless of the support for National Prohibition, the effects of the law were not always as positive. During the Prohibition years, law enforcement struggled to control the illicit liquor businesses. Though the illicit liquor trade included all manner of alcoholic beverages, beer-running presented its own challenges. To maximize profits from beer, large quantities of it were transported in single runs. In many instances, the high-volume production and distribution required cooperation from local officials and politicians. In general, the estimated alcohol consumption rates during Prohibition were less than before 1920, but they were still significant. Without legal regulation of alcohol sales, however, precise numbers are difficult to gauge. ${ }^{232}$

\footnotetext{
${ }^{230}$ De Lancy Carter, “Beer and Light Wines as Intoxicants," in Ernest H. Cherrington, ed., Proceedings of the Fifteenth International Congress Against Alcoholism, Held at Washington, D.C., U.S.A, September 2126, 1920 (Washington, D.C.: n.p., 1921): 50-53.

${ }^{231}$ A. Holitscher, "Beer as a Cause of Alcoholism," in Cherrington, Proceedings of Fifteenth International Congress Against Alcoholism, 54-55.

${ }^{232}$ Frank S. Adams, “Swing to Prohibition Repeal came suddenly After Long Fight,” New York Times, February 21, 1933.
} 
Economically, the beer industry suffered greatly from National Prohibition. Speaking to the Newcomen Society in 1955, president of Anheuser-Busch, Inc., August A. Busch, Jr. lamented, “The [Eighteenth] Amendment destroyed Anheuser-Busch’s preprohibition beer business.” He spoke on his father, August Busch, Sr.'s monetary loss from operating within the law while illicit beer production helped others increase their fortunes. Even so, Anheuser-Busch survived the Prohibition Era on syrup, non-alcoholic beverages, baker's yeast, and manufacturing truck bodies and refrigerated cabinets. ${ }^{233}$ Across the nation, breweries that could adapt operated on a similar vein. Still, production rates of legal near-beer at its height only reached one-third of the volume of preProhibition beer production. ${ }^{234}$ Breweries either adapted their businesses or closed. Brewing trade journals like the Western Brewer contained pages of advertisements selling everything from brewing equipment to the breweries themselves. Breweries suffering major losses after being forced to remodel or close protested but often to no avail.

Prior to the 1920s, the anti-Prohibition organizations consisted mainly of brewers, distillers, and other liquor trade associations. Even if opposed to the amendment, the public did not have a representative organization against National Prohibition. However, for reasons ranging from the protection of states' rights and home rule to defense against the rise in lawlessness in response to Prohibition, many people unaffiliated with the liquor industries called for modification or repeal of the Eighteenth Amendment. The

\footnotetext{
${ }^{233}$ August Busch, Jr., “Budweiser:” A Century of Character (New York: The Newcomen Society in North America, 1955), 14-16.

${ }^{234}$ Andrew Sinclair, Prohibition: The Era of Excess (Boston: Little, Brown and Company, 1962), 205-206.
} 
movement against Prohibition, remembered as "Repeal," began within its first year with organizations like the Association Against the Prohibition Amendment (AAPA) started in Washington, D.C. by William H. Stayton, attorney and former Navy captain from Delaware. Stayton did not have a stake in the liquor traffic, but he did support states’ rights and spoke out against centralized government. To him and AAPA members in general, states and local governments and not the federal government should have the power to implement prohibition measures. ${ }^{235}$

When it came time for Repeal, women once again organized, but this time against National Prohibition. As members of anti-alcohol organizations like the Woman's Christian Temperance Union (WCTU), thousands of women nationwide supported National Prohibition and celebrated its arrival. However, several women in the 1920s and 1930s organized against the Eighteenth Amendment. Organizations like the Women’s Organization for National Prohibition Reform (WONPR) received popular support. Appalled by the hypocrisy associated with Prohibition enforcement, Pauline Sabin resigned from the National Republican Committee and founded the WONPR in 1929. ${ }^{236}$ In the organization's "Declaration of Principles,” WONPR members penned the fundamental problems with National Prohibition. They found that the Eighteenth Amendment conflicted with the "basic American principle of local home rule and destroy[ed] the balance ... between powers delegated to the Federal authority and those

\footnotetext{
${ }^{235}$ Baron, Brewed in America, 311-321. Kyvig, Repealing National Prohibition, 36, 39-41.

${ }^{236}$ Pauline Sabin was the first woman to serve on the National Republican Committee. She helped found the Women's National Republican Club in New York City in 1921 and served as its first president until 1926. Kyvig, Repealing National Prohibition, 118-121. Grace C. Root, Women and Repeal: The Story of the Women's Organization for National Prohibition Reform (New York: Harper \& Brothers Publishers, 1934), 3-8.
} 
reserved to the sovereign states or to the people themselves.” Furthermore, they acknowledged the impracticality of a law to be respected or enforced without support by the "moral sense and the common conscience of the communities affected by it." ${ }^{237}$ With organizations like the AAPA and WONPR gaining public favor, so did the movement for Repeal.

Steadily, the influence of the anti-liquor groups who were influential in passing National Prohibition dwindled as the political and economic climate changed in the 1920s and early 1930s. The Anti-Saloon League and Woman’s Christian Temperance Union struggled with internal conflict and unsuccessful political campaigns. The Great Depression helped popularize the prospect of reinstating the legal liquor industries and the jobs that would come with them. Further discontent with prohibitionist President Herbert Hoover also helped popularize Repeal. Anti-Prohibitionists celebrated the election of the Democratic presidential candidate, Franklin D. Roosevelt, in November 1932. In March 1933, H. R. 3341, or the Cullen Bill, modified the Volstead Act to allow the production and sale of 3.2 percent beer in states without state prohibition laws. The bill also placed new taxes on beer, instituted brewers' license fees, and restricted commerce to states where beer was legal. Finally, the Twenty-First Amendment received the required three-fourths ratification, officially repealing the Eighteenth Amendment on December 5, 1933. ${ }^{238}$

\footnotetext{
${ }^{237}$ Root, Women and Repeal, 161.

${ }^{238}$ Kerr, K. Austin. Organized for Prohibition: A New History of the Anti-Saloon League. New Haven: Yale University Press, 1985), 242-274. Baron, Brewed in America, 321.
} 


\section{After Repeal until Craft Brewing Revolution: 1933 - late 1970s}

After Repeal, the beer industry slowly regenerated, but federal and state-specific restrictions placed made it difficult to regain the status of the pre-Prohibition industry. Governments heavily taxed beer and raised license fees, limited the amount and type of advertising for beer, and restricted methods of selling beer. Excise taxes ranged from \$0.32 to \$4.65 per barrel, depending on the state or district. States like Pennsylvania and Indiana put heavy taxes and made other restrictions on beer imported from other states. California even limited the size of outdoor beer signs. The National Industrial Recovery Act of 1933 included a Brewers Code, which the Federal Alcohol Administration Act of 1935 ultimately replaced. Both acts focused on methods of selling beer, making exclusive outlets impossible, in large part because of apprehension of the saloons from before Prohibition and the speakeasies popular during the Prohibition Era. ${ }^{239}$ In general, limitations and expenses promoted larger brewery consolidation and decreased the profitability of small, independent breweries. To breweries like Pabst Brewing Company,

\footnotetext{
${ }^{239}$ Objections to the saloon culture are covered extensively in Chapter 2. Even thirteen years after National Prohibition outlawed saloons, those influential in passing the Twenty-First Amendment and alcohol regulations maintained an aversion to the old saloon culture. Simultaneously, illicit public drinking places grew in popularity during the Prohibition Era, especially among the youth and young adults. The stigma of crime and vice followed these places just as they had the earlier saloons. Moreover, it became more commonplace for mixtures of men, women, races, and ethnicities to gather in public to drink, listen to music, dance, and socialize. By creating a legal structure that limited public drinking spaces and places, the legal authorities limited the activities that often accompanied such places. Thus, they embraced a form of control over the public through the legal system. Ultimately, the law successfully eliminated the old-style saloon, but Americans just found other places to meet and socialize. Historian Catherine Gilbert Murdock linked changing ideas of individualism and liberation with alcohol use that began in the Prohibition Era and continued afterwards. Catherine Gilbert Murdock, Domesticating Drink: Women, Men, and Alcohol in America, 1870-1940 (Baltimore: The Johns Hopkins University Press, 1998), 159-170. Perry R. Duis, The Saloon: Public Drinking in Chicago and Boston, 1880-1920 (1983; repr., Urbana, IL: Illini Books, 1999), 1-8, 274-303. Madelon Powers, Faces Along the Bar: Lore and Order in the Workingman's Saloon, 18701920 (Chicago: The University of Chicago Press, 1998), 234-236.
} 
outlawing the purchase of retail outlets was not seen as a problem. Instead, it opened markets that were once exclusively controlled. ${ }^{240}$

Laws limiting marketing and distribution of beer supported the larger breweries such as Anheuser-Busch, Miller, Pabst, and Coors in post-Prohibition America and made way for the light beer to dominate the beer culture. These brands remain nationally known and the most consumed in the United States. Collectively, they are referred to as "big beer.” Big beer companies returned to producing their light lagers as an appeal to American preferences for lighter, less-alcoholic beers. Breweries began using aluminum cans in the early 1930s, which transported and sold easily in grocery stores and stored easily in household refrigerators. Intensive advertising campaigns further solidified light beer in America's minds and homes. During the Second World War, beer production and popularity had increased to the point that the Food Distribution Administration required brewers to donate fifteen percent of their products to the American military as a morale booster. Unlike in the First World War, the low-alcohol beers did not threaten military efficiency for government officials. ${ }^{241}$

Small brewers could not compete and hardly survive in the post-Prohibition era with regulations benefiting big beer. First, regulations dictated that alcohol production and sale must occur in a three-tiered system. This required brewers to sell their beer to distributors, and then the distributors sold it to retail outlets. Second, the tax per barrel of beer remained the same for all sizes of brewing operations, big and small. Finally,

\footnotetext{
240 Thomas C. Cochran, The Pabst Brewing Company: The History of an American Business (New York: New York University Press, 1948), 366-368.

${ }^{241}$ Peter A. Kopp, Hoptopia: A World of Agriculture and Beer in Oregon's Willamette Valley (Oakland, CA: University of California Press, 2016), 114-118.
} 
homebrewing, an important factor in the craft brewing culture, remained illegal until the Cranston Law passed in 1978. In a similar fashion to the pre-Prohibition beer industry, those larger breweries that could sustain economic challenges also invested in aggressive advertising campaigns. These factors considered, competition proved too much for most smaller, independent breweries until changes in taxation and licensing laws developed later in the twentieth century. ${ }^{242}$

In the 1950s and 1960s, the big beer brands producing lighter, crisper, and lesshopped beers continually purchased local and regional breweries, effectively extending their markets and perpetuating their style of beer. Beer’s flavor trend coincided with Americans adding more homogenous, less-spiced foods to their diets. Fast food, canned goods, and, eventually, microwaved meals paired easily with the lighter beers. ${ }^{243}$

\section{Craft Beer Movement: Late 1970s - Present}

The light lagers produced by the big beer companies remained the only options for most Americans in the post-World War II era, but that changed as more Americans traveled abroad and got a taste for other styles of beer. Especially in the late 1960s, affluent Americans who desired more whole, local, and seasonal foods simultaneously embraced the fine wines and cuisine of Europe. Beer did not escape attention. Mostly, Americans imported beers from Europe and other parts of the world. ${ }^{244}$

\footnotetext{
242 Ibid., 173-188.

243 Ibid., 137-139. Ranjit S. Dighe, “A Taste for Temperance: How American Beer Got to be So Bland,” Business History 58, no. 5 (2016): 752-784.

${ }^{244}$ For more on American consumer culture in the twentieth century, refer to Susan Strasser, Charles McGovern, and Matthias Judt, eds., Getting and Spending: European and American Consumer Societies in the Twentieth Century (New York: Cambridge University Press, 1998). Kopp, Hoptopia, 175.
} 
Soon, however, curious and ambitious brewers emerged in the United States, independent of the big beer companies in what became known as the craft beer movement or craft brewing revolution. The origins of the craft beer movement are often attributed to a few brewers out of California. Most notable were Fritz Maytag with the Anchor Brewing Company of San Francisco and Jack McAuliffe with the New Albion Brewery of Sonoma. ${ }^{245}$ When Maytag purchased Anchor Brewing in 1965, it had a history reaching back to 1896 and was the only operational independent brewing company in the nation. Three characteristics of Maytag's brewery came to define a craft brewing operation: small size, independent, and traditional. Craft brewers embraced local, seasonal, and more traditional ingredients. Profiting remained challenging for craft brewers, but the desire for variety and an attraction to the beer brewing tradition steadily influenced more brewers to join what would become known as a revolution in the American beer industry. ${ }^{246}$

Slow changes in brewing regulations opened doors for small brewers, especially by the late 1970s. In 1976, Congress passed a tax equity law lowering the tax per barrel of beer for smaller breweries. Already mentioned, homebrewing became legal in 1978 with the Cranston Law, which fostered opportunities for beer-lovers to experiment with

\footnotetext{
${ }^{245}$ Maytag purchased the majority shares of Anchor Brewing Company in 1965. The brewery dated back to the late nineteenth century. It was one of very few independent breweries operating in the country at the time. Maytag's affection for local food culture and quality beer, coupled with his family's appliance and blue-cheese fortune, allowed him to slowly grow the brewery.

McAuliffe opened the New Albion Brewery with business partners, Suzy Stern and Jane Zimmerman. The brewery was the first “microbrewery.” It only lasted a few years, between 1976 and 1982, but it embodied the essence of the craft beer culture: high-quality beer, traditional styles, no additives, and independent of big beer. Kopp, Hoptopia, 174-176.

${ }^{246}$ Tom Acitelli, The Audacity of Hops: The History of America's Craft Beer Revolution (Chicago: Chicago Review Press, 2013), 10-11.
} 
brewing at home before opening operations of their own. Soon, home-brewing publications and organizations fed into the craft beer culture. Craft brewers shied away from the light beers produced by big beer and looked to other traditional styles of beer like stouts, porters, ales, and even darker lagers. They championed local ingredients and refused additives like corn or rice often used by larger brewers. Beginning on the West Coast, the craft brewing revolution grew across the nation between the late 1970s and into the 1990s.

Some states allowed breweries to self-distribute their products, breaking the threetiered system that drastically limited craft breweries’ profits. Even today, self-distribution laws vary across the country. States that allow self-distribution tend to have higher numbers of craft breweries. States that allow breweries to distribute out of the same place where the beer is brewed, in establishments known as brewpubs, have an even richer craft beer culture. ${ }^{247}$ Big beer production and sales continue to dominate the overall beer market, but craft beer is steadily growing with a five percent increase from 2016 to 2017.248

${ }^{247}$ Jacob Burgdorf, “Craft Breweries Abound in States with Fewer Regulations,” Foundation for Economic Education, September 19, 2016. https://fee.org/articles/craft-breweries-abound-in-states-with-fewerregulations/ (accessed March 25, 2018).

Conversely, states with greater restrictions limit the local craft beer industry, despite interest from local brewers. For example, due to strict regulations, Mark and Leslie Henderson opened the first brewery in the state of Mississippi since Prohibition in 2003. In 2012, the state legislature increased alcohol by volume for beer allowed, increasing attention to craft beers. Still, brewers are restricted from selfdistribution which further limits their ability to compete with big beer. Lisa Monti, "Despite Obstacles, Craft Beer Industry Growing,” Mississippi Business Journal (January 23, 2015).

${ }^{248}$ According to the 2017 sales and production data compiled by the Brewers Association, craft beer assumed 12.7 percent of the United States beer market by volume. Craft beer retail dollar sales were approximately \$26 billion, which was slightly more than twenty-three percent of the \$111.4 billion national beer market. Brewers Association, “National Beer Sales \& Production Data,” Brewers Association, https://www.brewersassociation.org/statistics/national-beer-sales-production-data/ (accessed May 12, 2018). 
Oregon is one example of a state where state regulations helped to increase the craft beer industry. The craft brewing revolution began in California and quickly spread up the West Coast into Oregon and Washington. The Willamette Valley in Oregon and Yakima Valley in Washington also produced aromatic hops with citrus and floral notes that attracted craft brewers looking for domestic hops providing bolder flavor choices. Early craft brewers like Maytag and McAuliffe used Pacific Northwest hops in their signature beers. Hop experimentations resumed at the Oregon Agricultural Experiment Station in Corvallis in 1930, and the U.S. Department of Agriculture funded a hop scientist position to breed American hop hybrids that could sustain agricultural diseases and increase production per plant. The experiments led to such hybrids frequently used by craft brewers as the Cascade, Willamette, Mount Hood, Crystal, Liberty, Sterling, Santaim, and Ultra varieties. The region’s brewers especially benefited from the "hop wars” that began in the 1990s where craft brewers around the country experimented with ways to add more varieties and more volume of hops to their brews.

With access to desirable ingredients and an existing bar and pub culture, places like Portland and Seattle quickly attracted craft brewing. In 1985, Oregon passed the Brewpub Bill, allowing brewers to sell their beer at their own breweries. Breweries and brewpubs opened across the state, beginning in the late 1980s and continuing to the present. As early as the 1990s, local publications named Portland as the "Craft Beer 
Capital of the World” and "Beervana."249 The craft beer movement continues to the present with more craft breweries and brewpubs opening across the country.

Viewed from a twenty-first century lens, the anti-alcohol campaigns between 1880 and 1920 had more instances of inconsistency, disorganization, and fragility than did the economic and social success of the American beer industry. On further examination, a law as encompassing as the Eighteenth Amendment, with the limitations imposed in the Volstead Act, does not appear as inevitable as some scholars over the last century suggested. The organizations most responsible for the success of National Prohibition, the Woman’s Christian Temperance Union, Prohibition Party, and AntiSaloon League changed strategies and experienced their own periods of success and failure. Despite high-license, local option, Sunday closings, statewide prohibitions, and intensely vocal and emotionally-charged campaigns, the beer industry continued to adapt and grow. Most anti-alcohol laws or regulations lasted for short periods of time. However, while not apparently inevitable, the Eighteenth Amendment did pass into law, and the United States did experience a National Prohibition Era.

National Prohibition may have affected the American beer industry, but it did not eliminate the American desire for the frothy, fermented beverage. The current popularity of beer in the United States ultimately grew out of a tradition that began with the first European settlers and carried through the trials presented by social reformers, National

\footnotetext{
249 The city of Portland alone has over one hundred breweries in the metropolitan area. Historian Peter Kopp detailed the essential connection between the craft beer revolution and the American hop industry, especially in the Pacific Northwest. Kopp, Hoptopia, 173-189.
} 
Prohibition, a rebuilding period, and a revolution. Brewers today harken to the beers of the past while making their own contributions to the art and science of brewing. The growing number of independent breweries and variety of beer styles produced within the United States, especially within areas with rich brewing histories, is a testament to the nation’s vibrant beer culture. 


\section{Bibliography}

\section{Unpublished Sources}

\section{Primary Sources}

Archival research was conducted at the Oregon Historical Society Research Library, Oregon State University Oregon Hops and Brewing Archives, and the City of Portland Archives and Records Center.

\section{Newspapers, Trade Journals, and Magazines}

American Public Health Association, Public Health Papers and Reports

American Brewers' Review

Anti-Saloon League of America, Proceedings

Journal of the Institute of Brewing

The American Medical Temperance Quarterly

The British Medical Journal

The Journal of Home Economics

The Journal of the American Medical Association

The New York Times

The Oregonian

The Western Brewer: and Journal of the Barley, Malt and Hop Trades

The Wine and Spirit Bulletin

The Yearbook of the United States Brewers' Association

\section{Published Books, Articles, and Government Publications}

Andreae, Percy. The Prohibition Movement: In Its Broader Bearings Upon Our Social, Commercial, and Religious Liberties. Chicago: Felix Mendelsohn, 1915.

Angell, George T. "Remarks of Mr. Angell,” Journal of Social Science 13 (1 Mar 1881): 130-132.

Bradley, Lawson G., ed., Official Guide to the Lewis and Clark Centennial Exposition, Portland, Oregon, June 1 to October 15, 1905. Portland, OR: Lewis and Clark Centennial and American Pacific Exposition and Oriental Fair, 1905.

Buell, Mrs. C.S. "Household Adjustment to Changing Industrial Conditions.” Lake Placid Conference on Home Economics: Proceedings of the Ninth Annual Conference (1-6 July 1907): 93-99.

Calkins, Raymond. Substitutes for the Saloon: An Investigation Originally Made for the Committee of Fifty. 2nd ed. New York: Houghton Mifflin Company, 1919. 
Carter, Henry. The Control of the Drink Trade in Britain: A Contribution to National Efficiency During the Great War, 1915-1918. 2nd ed. New York: Longmans, Green and Co., 1919.

Cherrington, Ernest Hurst, ed. Standard Encyclopedia of the Alcohol Problem. 6 vols. Westerville, OH: American Issue Publishing Company, 1925.

--------, ed. Proceedings of the Fifteenth International Congress Against Alcoholism, Held at Washington, D.C., U.S.A, September 21-26, 1920. Washington, D.C.: n.p., 1921.

--------. The Evolution of Prohibition in the United States of America: A Chronological History of the Liquor Problem and the Temperance Reform in the United States from the Earliest Settlements to the Consummation of National Prohibition. Westerville, OH: The American Issue Press, 1920.

Duniway, Abigail Scott. Path Breaking: An Autobiographical History of the Equal Suffrage Movement in Pacific Coast States. 2nd ed. Portland, OR: James, Kerns \& Abbott Co., 1914.

Edwards, Justin. The Temperance Manual. London: S.W. Partridge \& Co., 1871.

Farmer, Fannie Merritt. The Boston Cooking-School Cook Book. Rev. ed. Boston: Little, Brown, and Company, 1929.

Fehlandt, August F. A Century of Drink Reform in the United States. Cincinnati: Jennings and Graham, 1904.

Feldman, Herman. Prohibition: Its Economic and Industrial Aspects. New York: D. Appleton and Company, 1930.

Ford, Robert, ed. Vagabond Songs and Ballads of Scotland, With Many Old and Familiar Melodies. 2nd ed. 2 vols. London: Alexander Gardner, 1901.

Fox, Hugh F. "The Prosperity of the Brewing Industry.” The Annals of the American Academy of Political and Social Science 34, no. 3 (Nov., 1909): 47-57.

--------. “The Saloon Problem.” The Annals of the American Academy of Political and Social Science 32 (Nov., 1908): 61-68.

Frankland, Percy. “The Work of Pasteur and What it has Led to.” Journal of the Federated Institutes of Brewing 1, no. 7 (July 1895): 19-36. 
Hacker, Louis M. “The Rise and Fall of Prohibition.” Current History 36, no. 6 (Sept. 1, 1932): 662-672.

Johnson, S. W. "Adulterations in Food." Journal of Social Science 13 (Mar 01, 1881): 99-123.

Koren, John. Economic Aspects of the Liquor Problem: An Investigation Made for the Committee of Fifty under the Direction of Henry W. Farnham, Secretary of the Economic Sub-Committee. Boston: Houghton, Mifflin and Company, 1899.

Krout, John Allen. The Origins of Prohibition. New York: Russell \& Russell, 1967. First published 1925 by Alfred A. Knopf, Inc.

London, Jack. John Barleycorn. New York: The Century Co., 1913.

Meeker, Ezra. Hop Culture in the United States, Being a Practical Treatise on Hop Growing in Washington Territory, From the Cutting to the Bale. Puyallup, Washington Territory: E. Meeker \& Co., 1883.

Monahan, M., ed. A Text-book of True Temperance. New York: United States Brewers’ Association, 1909.

National Wholesale Liquor Dealers Association of America. The Anti-Prohibition Manual: A Summary of Facts and Figures Dealing with Prohibition. Cincinnati: National Wholesale Liquor Dealers Association of America, 1916, 1918.

Nicholson, S.E. “The Local-Option Movement.” The Annals of the American Academy of Political and Social Science 32 (Nov. 1908): 1-5.

One Hundred Years of Brewing: A Complete History of the progress made in the Art, Science and Industry of Brewing in the world, particularly during the last Century. Chicago: H.S. Rich \& Co., 1901.

Pasteur, Louis. Studies on Fermentation: The Diseases of Beer, Their Causes, and the Means of Preventing Them. Translated by Frank Faulkner and David Constable Robb. London: Macmillan \& Co., 1879.

Root, Grace C. Women and Repeal: The Story of the Women's Organization for National Prohibition Reform. New York: Harper \& Brothers Publishers, 1934.

Rush, Benjamin. An Inquiry into the Effects of Ardent Spirits upon the Human Body and Mind, with An Account of the Means of Preventing and of the Remedies for Curing Them. 6th ed. New York: Cornelius Davis, 1811. 
Salem, F.W. Beer, Its History and Its Economic Value as a National Beverage. 1880; repr. New York: Arno Press Inc., 1972.

Schlüter, Hermann. The Brewing Industry and the Brewery Workers' Movement in America. Cincinnati: International Union of United Brewery Workmen of America: 1910.

Sinclair, Upton. The Cup of Fury. Manhasset, NY: Channel Press, Inc., 1956.

--------. The Jungle. New York: Doubleday, Page \& Company, 1906.

Stelzle, Charles. Why Prohibition! New York: George H. Doran Company, 1918.

Stevens, Lillian M. N. “The Work of the National Woman’s Christian Temperance Union.” The Annals of the American Academy of Political and Social Science 32, Regulation of the Liquor Traffic (Nov. 1908): 508-512.

Stillé, Alfred and John M. Maisch. The National Dispensatory: Containing the Natural History, Chemistry, Pharmacy, Actions and Uses of Medicines, Including those Recognized in the Pharmacopoeias of the United States, Great Britain, and Germany, with Numerous References to the French Codex. 2nd ed. Philadelphia: Henry C. Lea, 1879.

Thomann, Gallus. Liquor Laws of the United States: Their Spirit and Effect. New York: N.Y. Economical Printing Co. for the United States Brewers’ Association, 1885.

--------. The Effects of Beer upon Those Who Make and Drink It, A Statistical Sketch. New York: The United States Brewers’ Association, 1886.

United States Brewers' Association, Documentary History of the United States Brewers' Association. 2 parts. New York: United States Brewers’ Association, 1896, 1898.

United States House Committee on Interstate and Foreign Commerce. Hearings before the Committee on Interstate and Foreign Commerce of the House of Representatives on the Pure-Food Bills H.R. 3109, 12348, 9352, 276, and 4342 for Preventing the Adulteration, Misbranding, and Imitation of Foods, Beverages, Candies, Drugs, and Condiments in the District of Columbia and the Territories, and For Regulating Interstate Traffic Therein, and For Other Purposes. Washington, D.C.: Government Printing Office, 1902.

United States Senate Committee on the Judiciary. Brewing and Liquor Interests and German Propaganda: Hearings Before a Subcommittee on the Committee on the Judiciary, United States Senate, Sixty-Fifth Congress, Second Session, Pursuant to S. RES. 307, A Resolution Authorizing and Directing the Committee on the 
Judiciary to Call for Certain Evidence and Documents Relating to Charges Made Against the United States Brewers' Association and Allied Interests and to Submit a Report of Their Investigation to the Senate. Vol. 1. Washington, D.C.: Government Printing Office, 1919.

Wells, David A. The Theory and Practice of Taxation. New York: D. Appleton and Company, 1900.

Wiley, Harvey W. Harvey W. Wiley: An Autobiography. Indianapolis: The Bobbs-Merrill Company, 1930.

Wood, Charles Erskine Scott. “The Skidmore Fountain.” Oregon Historical Quarterly 34, no.6 (Jun., 1933): 97-102.

\section{Secondary Sources}

Aaron, Paul and David Musto. "Temperance and Prohibition in America: A Historical Overview.” In Alcohol and Public Policy: Beyond the Shadow of Prohibition, Panel on Alternative Policies Affecting the Prevention of Alcohol Abuse and Alcoholism, edited by Mark H. Moore and Dean R. Gerstein, 127-181. Washington, D.C.: National Academy Press, 1981.

Abbott, Carl. Portland in Three Centuries: The Place and the People. Corvallis, OR: Oregon State University Press, 2011.

Acitelli, Tom. The Audacity of Hops: The History of America's Craft Beer Revolution. Chicago: Chicago Review Press, 2013.

Arndt Anderson, Heather. Portland: A Food Biography. Lanham, MD: Rowman \& Littlefield, 2015.

Banis, David and Hunter Shobe. Portlandness: A Cultural Atlas. Seattle, WA: Sasquatch Books, 2015.

Barleen, Steven D., "'Rushing the growler': can rushing and working-class politicization in the Gilded Age and Progressive Era." Labor History 55, no. 4 (October 2014): 519-537, http://www-tandfonlinecom.proxy.lib.pdx.edu/doi/pdf/10.1080/0023656X.2014.948710 (accessed February 9, 2016).

Baron, Stanley. Brewed in America: A History of Beer and Ale in the United States. Boston: Little, Brown, and Company, 1962. 
Barrows, Susanna and Robin Room, eds. Drinking: Behavior and Belief in Modern History. Berkeley and Los Angeles: University of California Press, 1991.

Biltekoff, Charlotte. Eating Right in America: The Cultural Politics of Food \& Health. Durham, NC: Duke University Press, 2013.

Blocker, Jack S., Jr., David M. Fahey, and Ian R. Tyrell, eds. Alcohol and Temperance in Modern History: An International Encyclopedia. 2 vols. Santa Barbara, CA: ABC-CLIO, Inc., 2003.

Bordin, Ruth. Woman and Temperance: The Quest for Power and Liberty, 1873-1900. Philadelphia: Temple University Press, 1981.

Brewers Association. “National Beer Sales \& Production Data.” Brewers Association. https://www.brewersassociation.org/statistics/national-beer-sales-production-data/ (accessed May 12, 2018).

Burgdorf, Jacob. "Craft Breweries Abound in States with Fewer Regulations.” Foundation for Economic Education. September 19, 2016. https:/fee.org/articles/craft-breweries-abound-in-states-with-fewer-regulations/ (accessed March 25, 2018).

Busch, Jr., August. “Budweiser:” A Century of Character. New York: The Newcomen Society in North America, 1955.

Caetano Raul, Catherine L. Clark, and Tammy Tam. “Alcohol Consumption Among Racial / Ethnic Minorities: Theory and Research.” Alcohol Health \& Research World 22. No. 4 (Fall 1998): 233-241.

Caswell, John E. “The Prohibition Movement in Oregon: Part 1, 1836-1904.” Oregon Historical Quarterly 39. No. 3 (Sept. 1938): 235-261.

--------. “The Prohibition Movement in Oregon II. 1904-1915.” Oregon Historical Quarterly 40. No. 1 (Mar. 1939): 64-82.

Chartier Karen and Raul Caetano. "Ethnicity and Health Disparities in Alcohol Research.” Alcohol Research \& Health 33. Nos. 1-2 (Winter-Spring 2010): 152160.

Clark, Norman H. Deliver Us From Evil: An Interpretation of American Prohibition. New York: W.W. Norton \& Company, Inc., 1976. 
Chamberlain, Adam, Alixandra B. Yanus, and Nicholas Pyeatt. "The Connection Between the Woman's Christian Temperance Union and the Prohibition Party.” SAGE Open 6. No. 4 (2016): 1-8.

Cochran, Thomas C. The Pabst Brewing Company: The History of an American Business. New York: New York University Press, 1948.

Dighe, Ranjit S. “A Taste for Temperance: How American Beer Got to be So Bland.” Business History 58. No. 5 (2016): 752-784.

Duffy, John. The Sanitarians: A History of American Public Health. Urbana, IL: University of Illinois Press, 1990.

Duis, Perry R. The Saloon: Public Drinking in Chicago and Boston, 1880-1920. 1983. Reprint, Urbana, IL: Illini Books, 1999.

Dunlop, Pete. Portland Beer: Crafting the Road to Beervana. Charleston, SC: American Palate, 2013.

DuPuis, E. Melanie. Nature's Perfect Food: How Milk Became America's Drink. New York: New York University Press, 2002.

Edman, Johan. "Temperance and Modernity: Alcohol Consumption as a Collective Problem, 1885-1913.” Journal of Social History 49. No. 1 (Fall 2015): 20-52.

--------. "Transnational Nationalism and Idealistic Science: The Alcohol Question between the Wars." Social History of Medicine 29. No. 3 (2016): 590-610.

Fahey, David M. “Old-Time Breweries: Academic and Breweriana Historians,” Ohio History 116. (2009): 101-121.

Fink, Leon. The Long Gilded Age: American Capitalism and the Lessons of a New World Order. Philadelphia: University of Pennsylvania Press, 2015.

Freidberg, Susanne. Fresh: A Perishable History. Cambridge: The Belknap Press of Harvard University Press, 2009.

Gusfield, Joseph R. Symbolic Crusade: Status Politics and the American Temperance Movement. Urbana, IL: University of Illinois Press, 1963.

Hamm, Richard F. Shaping the Eighteenth Amendment: Temperance Reform, Legal Culture, and the Polity, 1880-1920. Chapel Hill, NC: The University of North Carolina Press, 1995. 
Haydu, Jeffrey. "Frame Brokerage in the Pure Food Movement, 1879-1906.” Social Movement Studies 11. No. 1 (January 2012): 97-112.

Ingraham, Aukjen T. "Henry Weinhard \& City Brewery.” Oregon Historical Quarterly 102. No. 2 (Summer, 2001): 180-195.

Kell, John. "These 4 Brewers Have Been Booted from the Top 50 Craft Beers List.” Fortune. http://fortune.com/2017/03/15/mergers-change-craft-brewers-list/ (accessed May 11, 2018).

Kennedy, David M. Over Here: The First World War and American Society. New York: Oxford University Press, 1980.

Kerr, K. Austin. Organized for Prohibition: A New History of the Anti-Saloon League. New Haven: Yale University Press, 1985.

Kopp, Peter A. “'Hop Fever’ in the Willamette Valley: The Local and Global Roots of a Regional Specialty Crop.” Oregon Historical Quarterly 112. No. 4 (Winter 2011): 406-433.

Hoptopia: A World of Agriculture and Beer in Oregon's Willamette Valley. Oakland, CA: University of California Press, 2016.

Kyvig, David E. Repealing National Prohibition. 2nd ed. Kent, OH: The Kent State University Press, 2000.

Laband, David N. and Deborah Hendry Heinbuch. Blue Laws: The History, Economics, and Politics of Sunday-Closing Laws. Lexington, MA: Lexington Books D.C. Heath and Company, 1987.

Levenstein, Harvey. Revolution at the Table: Transformation of the American Diet. Berkeley, CA: University of California Press, 2003.

Meier, Gary and Gloria Meier. Brewed in the Pacific Northwest: A History of BeerMaking in Oregon and Washington. Seattle: Fjord Press, 1991.

Mittelman, Amy. Brewing Battles: A History of American Beer. New York: Algora Publishing, 2008.

Murdock, Catherine Gilbert. Domesticating Drink: Women, Men, and Alcohol in America, 1870-1940. Baltimore: The Johns Hopkins University Press, 1998.

Odegard, Peter H. Pressure Politics: The Story of the Anti-Saloon League. New York: Columbia University Press, 1928. 
Ogle, Maureen. Ambitious Brew: The Story of American Beer. Orlando, FL: Harcourt, Inc., 2006.

Patterson, Mark and Nancy Hoalst-Pullen, eds. The Geography of Beer: Regions, Environment, and Societies. New York: Springer, 2014.

Paulson, Ross Evans. Women's Suffrage and Prohibition: A Comparative Study of Equality and Social Control. Glenview, IL: Scott, Foresman and Company, 1973.

Powers, Madelon. Faces Along the Bar: Lore and Order in the Workingman's Saloon, 1870-1920. Chicago: The University of Chicago Press, 1998.

Rorabaugh, W. J. The Alcoholic Republic: An American Tradition. New York: Oxford University Press, 1979.

Rose, Kenneth D. American Women and the Repeal of Prohibition. New York: New York University Press, 1996.

Ross, William G. World War I and the American Constitution. New York: Cambridge University Press, 2017.

Rothstein, William G. American Physicians in the Nineteenth Century: From Sects to Science. Baltimore: The Johns Hopkins University Press, 1972.

Rumbarger, John J. Profits, Power, and Prohibition: Alcohol Reform and the Industrializing of America, 1800-1930. Albany, NY: State University of New York Press, 1989.

Schiefenhövel, Wulf and Helen Macbeth, eds. Liquid Bread: Beer and Brewing in CrossCultural Perspective. New York: Berghahn Books, 2013.

Schrad, Mark Lawrence. "Policy Effectiveness in Historical Context: Pre-Prohibition Liquor-Control Studies Revisited.” World Medical \& Health Policy 6. No. 3 (2014): 187-202.

Sinclair, Andrew. Prohibition: The Era of Excess. Boston: Little, Brown and Company, 1962.

Smock, Raymond W., ed. Landmark Documents on the U.S. Congress. Washington, D.C.: Congressional Quarterly, Inc., 1999. 
Soden, Dale E. “The Woman’s Christian Temperance Union in the Pacific Northwest: The Battle for Cultural Control.” The Pacific Northwest Quarterly 94. No. 4 (Fall 2003): 197-207.

Strasser, Susan, Charles McGovern, and Matthias Judt, eds. Getting and Spending: European and American Consumer Societies in the Twentieth Century. New York: Cambridge University Press, 1998.

Strasser, Susan. Never Done: A History of American Housework. New York: Pantheon Books, 1982.

Szymanski, Ann-Marie. Pathways to Prohibition: Radicals, Moderates, and Social Movement Outcomes. Durham, NC: Duke University Press, 2003.

Tomlan, Michael A. Tinged With Gold: Hop Culture in the United States. Athens, GA: University of Georgia Press, 1992.

Tyrrell, Ian. Reforming the World: The Creation of America's Moral Empire. Princeton: Princeton University Press, 2010.

Veit, Helen Zoe. Modern Food, Moral Food: Self-Control, Science, and the Rise of Modern American Eating in the Early Twentieth Century. Chapel Hill: The University of North Carolina Press, 2013.

Ward, Jean M. and Elaine A. Maveety, eds. "Yours for Liberty: Selections from Abigail Scott Duniway’s Suffrage Newspaper. Corvallis, OR: Oregon State University Press, 2000.

Wilson, Bee. Swindled: From Poison Sweets to Counterfeit Coffee - The Dark History of the Food Cheats. London: John Murray, 2008.

Wiltse, Jeffrey. "'I Like to Get Around': City Girls in Chicago Music Saloons, 18581906." Journal Of Urban History 39. No. 6 (November 2013): 1125-1145.

Wood, Peter. “John Barleycorn: The Evolution of a Folk-song Family.” Folk Music Journal 8. No. 4 (2004): 438-455.

Young, James Harvey. Pure Food: Securing the Federal Food and Drugs Act of 1906. Princeton, NJ: Princeton University Press, 1989. 